Ghislain Mwamba Tshibangu

\title{
INTERVENING ASPECTS ON THE INFLUENCE OF STRATEGIC ENVIRONMENTAL ASSESSMENT ON THE DEVELOPMENT OF PLANS AND PROGRAMS IN BRAZIL
}

Ph.D. Thesis presented to the Graduate Program in Environmental Science Engineering at the Escola de Engenharia de São Carlos, Universidade de São Paulo to obtain the Degree of Doctor of Science.

Advisor: Prof. Dr. Marcelo Montaño 
AUTORIZO A REPRODUÇÃO TOTAL OU PARCIAL DESTE TRABALHO, POR QUALQUER MEIO CONVENCIONAL OU ELETRÔNICO, PARA FINS DE ESTUDO E PESQUISA, DESDE QUE CITADA A FONTE.

Ficha catalográfica elaborada pela Biblioteca Prof. Dr. Sérgio Rodrigues Fontes da EESC/USP com os dados inseridos pelo(a) autor(a).

\begin{tabular}{|c|c|}
\hline M877i & $\begin{array}{l}\text { Mwamba Tshibangu, Ghislain } \\
\text { Intervening aspects on the influence of Strategic } \\
\text { Environmental Assessment on the development of Plans } \\
\text { and Programs in Brazil / Ghislain Mwamba Tshibangu; } \\
\text { orientador Marcelo Montaño. São Carlos, } 2019 \text {. }\end{array}$ \\
\hline & $\begin{array}{l}\text { Tese (Doutorado) - Programa de Pós-Graduação e } \\
\text { Área de Concentração em Ciências da Engenharia } \\
\text { Ambiental -- Escola de Engenharia de São Carlos da } \\
\text { Universidade de São Paulo, } 2019 \text {. }\end{array}$ \\
\hline & $\begin{array}{l}\text { 1. Strategic Environmental Assessment. 2. outcome. } \\
\text { 3. benefit. 4. impact. 5. influence. 6. Brazil. I. } \\
\text { Título. }\end{array}$ \\
\hline
\end{tabular}

Eduardo Graziosi Silva - CRB - 8/8907 


\section{FOLHA DE JULGAMENTO}

Candidato: Biólogo GHISLAIN MWAMBA TSHIBANGU.

Título da tese: "Fatores intervenientes na influência da Avaliação Ambiental Estratégica sobre a formulação de planos e programas no Brasil".

Data da defesa: 06/12/2019.

\section{Comissão Julgadora:}

Prof. Associado Marcelo Montaño

\section{(Orientador)}

(Escola de Engenharia de São Carlos/EESC)

Prof. Titular Marcelo Marini Pereira de Souza

(Faculdade de Filosofia, Ciências e Letras de Ribeirão Preto/FFCLRP-USP)

\section{Prof. Associado Evandro Mateus Moretto}

(Escola de Artes, Ciências e Humanidades/EACH-USP)

Prof. Dr. Alberto de Freitas Castro Fonseca

(Universidade Federal de Ouro Preto/UFOP)

Prof. Dr. Tomás Augusto Barros Ramos

(Universidade Nova de Lisboa/Portugal)

\section{Resultado:}

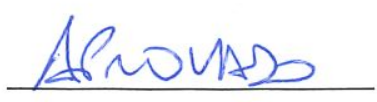

\section{Aprorado}

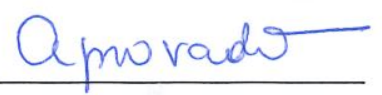

AlROVIANO

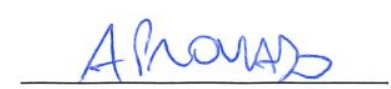

Coordenador do Programa de Pós-Graduação em Ciências da Engenharia Ambiental:

Prof. Associado Frederico Fabio Mauad

Presidente da Comissão de Pós-Graduação:

Prof. Titular Murilo Araujo Romero 
To my wife Olive and my daughter Orilia with love, gratitude and admiration for their presence and tireless support throughout the preparation period of this study. 


\section{ACKNOWLEDGEMENTS}

First and foremost, I wish to thank God for my creator. Thanks to Marcelo Montaño, the supervisor of my $\mathrm{PhD}$ thesis. I am also most grateful for the valuable support provided by the Núcleo de Estudo em Política Ambiental, particularly by my colleague Joyce Elanne Mateus Celestino. I am grateful for the cooperation which I have received from everyone, particularly postgraduate students who agreed to be interviewed and who returned my questionnaires. Thanks to my examiners for their critical comments.

I would also like to thank Olive Mangolo and Anne Malvestio for their comments on pilot questionnaires and thesis text. Thanks again to olive Mangolo, who helped me with the English translations.

Thanks also to Tiago, Priscilla, Izabela, Fernanda and Diana for always interesting discussions and support. Finally, I would like to thank my whole family and all my friends for their enduring support without which I would have never been able to complete this thesis.

I gratefully acknowledge the financial support of the CNPq. 


\begin{abstract}
TSHIBANGU, G. M. Intervening aspects on the influence of Strategic Environmental Assessment on the development of Plans and Programs in Brazil. 128p. Thesis (PhD) Escola de Engenharia de São Carlos, Universidade de São Paulo, São Carlos, 2019.

Strategic Environmental Assessment (SEA) is an impact assessment tool that can facilitate sustainable development and improve decision-making by introducing environmental concern early in planning processes. In recent years, there has been a rising interest in studies on the effectiveness of SEA, which is measured by comparing the instrument outcomes and theoretical, procedural and objective aspects of its performance. This confrontation highlights the tool influence on decisions taken and, above all, its actual effects on the environment. Literature on SEA indicates that there is a need to identify evidence regarding impacts of SEA on the process of formulating and implementing strategic actions, especially in order to highlight its real benefits and its contribution to the society. Based on these considerations, the $\mathrm{PhD}$ thesis aims to explore the extent to which the context may influence on SEA effectiveness based on perceived SEA outcomes. Considering characteristics of the SEA system in Brazil, the methodology used in this study involved the following steps: (i) identification of actors and institutions involved in the SEA processes, and (ii) identification of SEA outcome(s) through questionnaire and interview survey. The second step involved previously a systematic analysis of literature focusing on SEA outcomes and impacts on decision-making. A total of 68 SEAs applied in Brazil from 1997 to 2018 was identified. The findings indicate three main aspects that may explain the lengthy process of introduction of SEA in plan- and policy-making in the country: (i) lack of proper SEA legislation; (ii) the influence of Environmental Impact Assessment practice, and; (iii) the strong influence of the environmental licensing culture. Nevertheless, SEA contribute to improving communication between stakeholders along the planning process and to providing a better level of information for lower tiers of decisionmaking. In spite of the minor influences on the nature of the strategic action, as reported by interviewees, valuable lessons credited to SEA have been learnt.
\end{abstract}

Keywords: Strategic Environmental Assessment, outcome, impact, influence, benefit, Brazil. 


\section{RESUMO}

\section{TSHIBANGU, G. M. Aspectos intervenientes na influência da Avaliação Ambiental}

Estratégica sobre a formulação de Planos e Programas no Brasil. 128p. Tese (Doutorado)

- Escola de Engenharia de São Carlos, Universidade de São Paulo, São Carlos, 2019.

A Avaliação Ambiental Estratégica (AAE) é uma ferramenta de avaliação de impacto que pode facilitar o desenvolvimento sustentável e melhorar a tomada de decisões, introduzindo a variável ambiental no início dos processos de planejamento. Nos últimos anos, notou-se um interesse crescente nos estudos sobre a efetividade da AAE, que é medida pela comparação dos resultados do instrumento aos aspectos teóricos, procedimentais e objetivos de seu desempenho. Esse confronto destaca a influência da ferramenta nas decisões tomadas e, acima de tudo, seus efeitos palpáveis no meio ambiente. A literatura sobre AAE indica a necessidade de identificar evidências de impactos da AAE sobre o processo de formulação e implementação de ações estratégicas, especialmente para destacar seus reais benefícios e sua contribuição para a sociedade. Com base nessas considerações, o objetivo dessa tese é explorar até que ponto o contexto pode influenciar na efetividade da AAE com base nos resultados percebidos da AAE. Considerando as características do sistema de AAE no Brasil, a metodologia utilizada neste estudo envolveu as seguintes etapas: (i) identificação de atores e instituições envolvidos nos processos de $\mathrm{AAE}$ e (ii) identificação de resultados de $\mathrm{AAE}$ por meio de questionário e pesquisa de entrevista. O segundo passo envolveu anteriormente uma análise sistemática da literatura com foco nos resultados e nos impactos da AAE na tomada de decisões. Foram identificados 68 AAEs aplicadas no Brasil de 1997 a 2018. Os resultados indicam três aspectos principais que podem explicar o longo processo de introdução da AAE na elaboração de planos e políticas no país: (i) falta de legislação adequada da AAE; (ii) a influência da prática de Avaliação de Impacto Ambiental, e; (iii) a forte influência da cultura de licenciamento ambiental. No entanto, a AAE contribui para melhorar a comunicação entre as partes interessadas ao longo do processo de planejamento e fornecer uma informação de qualidade para os níveis mais baixos de tomada de decisão. Apesar das pequenas influências sobre a ação estratégica, conforme relatado pelos entrevistados, foram aprendidas lições valiosas creditadas à AAE.

Palavras-chaves: Avaliação Ambiental Estratégica, resultado, impacto, influência, benefício, Brasil. 


\section{List of figures}

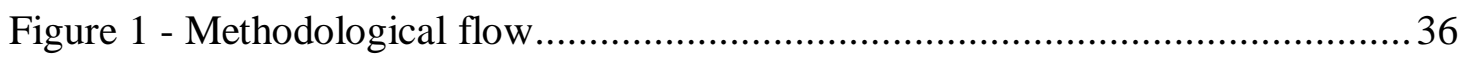

Figure 2 - Linkage of outcomes and IAIA performance criteria................................43

Figure 3 - Questions of group A "is integrated"..................................................65

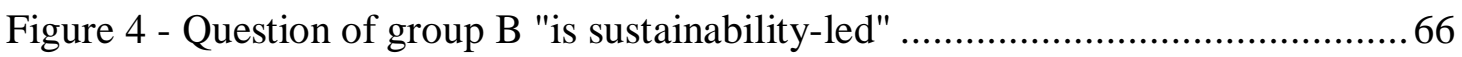

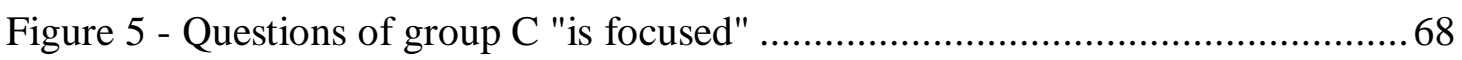

Figure 6 - Questions of group D "is accountable"..............................................6 69

Figure 7 - Questions of group E "is participative" ................................................ 71

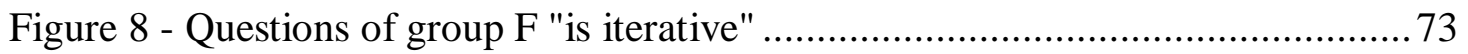

Figure 9 - Questions of group G "is innovative" .................................................74 


\section{List of Tables}

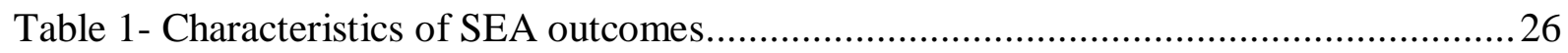

Table 2 - Outcomes of SEA on strategic decisions and related contextual factors (follows) .. 32

Table 3 - Linking of IAIA performance criteria and SEA outcomes ................................. 44

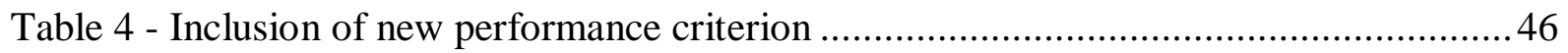

Table 5 - Sectors and number of SEA cases in Brazil between 1997 and 2018.....................53

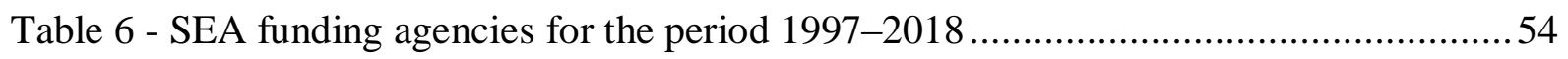

Table 7 - Top 10 SEA proponents for the period 1997-2018 …......................................55

Table 8 - Top 10 SEA consultancies for the period 1997-2018 ….....................................56

Table 9 - Number of SEA individual actors for the period 1997-2018_..............................57

Table 10 - SEAs without participants involved in the questionnaire survey ........................61

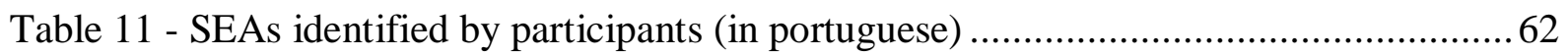

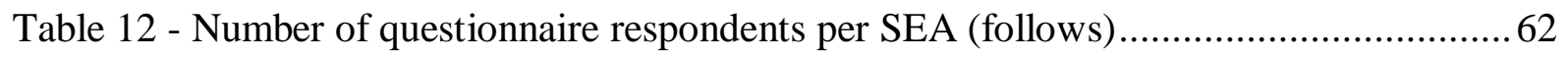

Table 13 - Influencing relation between outcomes and criteria (follows) ............................ 82 


\section{List of acronyms}

COPPE - Alberto Luís Coimbra institute of postgraduate and research in engineering EA: Environmental Assessment

EIA - Environmental Impact Assessment

EU - European Union

IA - Impact Assessment

IAIA - International Association for Impact Assessment

IADB - Inter-American Development Bank

LIMA - Interdisciplinary environment laboratory

MDA - Multilateral Development Agency

NEPA - National Environmental Policy Act

PPP - Politics, Plans and Programs

UFRJ - Federal University of Rio de Janeiro

SEA - Strategic Environmental Assessment

SOMA - Environmental Solutions (Soluções em Meio Ambiente)

WB - World Bank 


\section{SUMMARY}

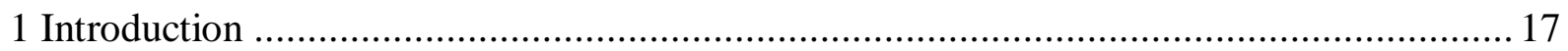

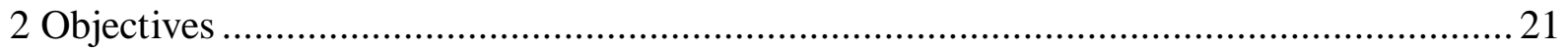

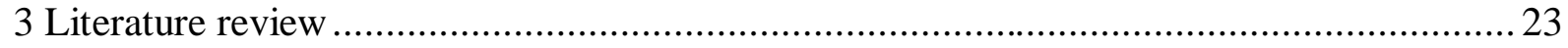

3.1 Strategic Environmental Assessment: principles and conceptual background.............23

3.2 Effectiveness and outcomes of the Strategic Environmental Assessment ................... 24

3.3 Strategic Environmental Assessment in Brazil: contextual aspects ............................28

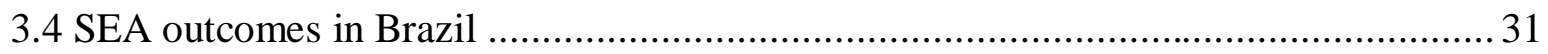

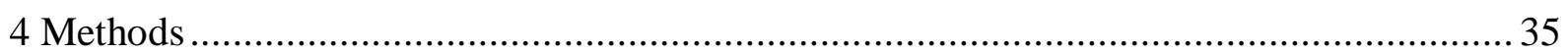

4.1 Methodological approach based on SEA literature for a more systematic identification of SEA outcomes in decision-making processes ..................................................... 36

4.2 Characterization of actors and institutions potentially influenced by the SEA process

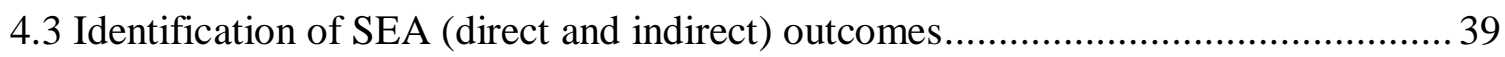

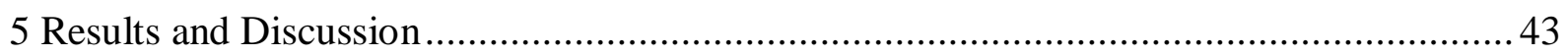

5.1 Methodological approach based on SEA literature for a systematic identification of SEA

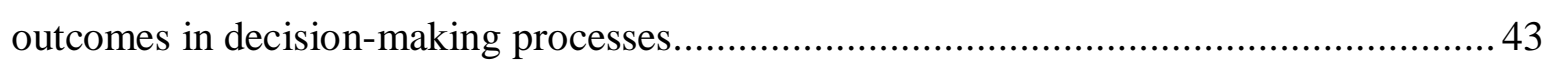

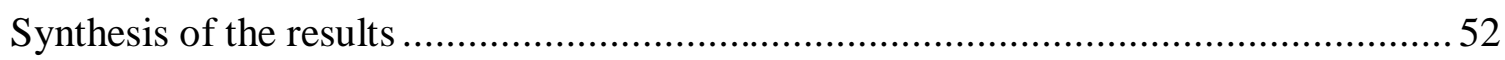

5.2 Identification of individual and institutional actors involved in the SEA processes ..... 52

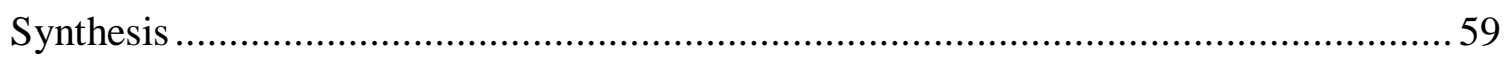

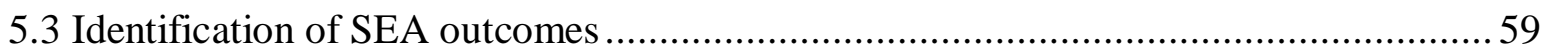

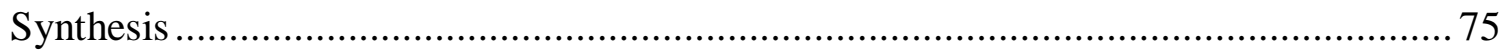

5.4 Intervening aspects on the effectiveness of SEA in Brazil ...................................... 76

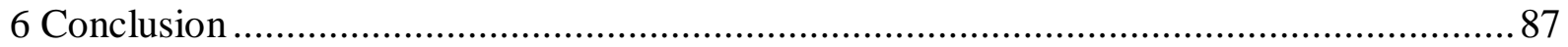

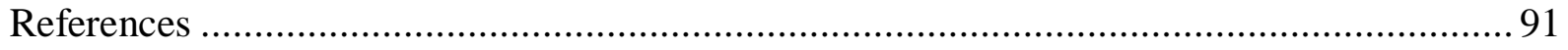

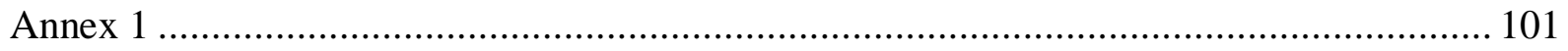

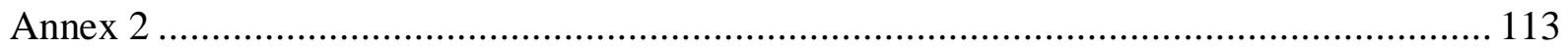




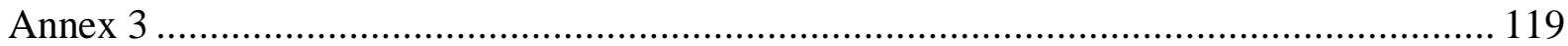




\section{Introduction}

Strategic Environmental Assessment (SEA) is widely recognised as a tool for identifying potential impacts of strategic actions and promoting sustainable development, immersed in a rapidly developing field worldwide (TETLOW; HANUSCH, 2012). Its main objective is to promote the integration of environmental concerns in higher levels of decision-making (THERIVEL, 2004; FISCHER, 2007).

SEA has developed a strong institutional basis and is internationally well established at national and local levels and in development cooperation programmes (MULDER, 2011), moreover after its introduction in the European Union (EU) in 2001. Also, a growing number of developing countries are more responsible to the environmental impacts of Policies, Plans and Programs (PPPs), and many have developed SEA legislation assisted by Multilateral Development Agencies (MDA) (DALAL-CLAYTON; SADLER, 2005; TSHIBANGU, 2018; VICTOR; AGAMUTHU, 2014).

SEA is said to be highly influenced by specific characteristics of strategic decision-making, which include the type of strategy that is being developed, its purposes and objectives, the linkages to other plans and programmes, amongst others (Fischer, 2007; João, 2007; Therivel, 2010; Bina et al., 2011). Hence, flexibility and capacity to adapt to the context of application are considered two of the main characteristics of a SEA system. However, precisely how it should be adapted is still to be clarified, particularly in relation to political willingness (HILDING-RYDEVIK; BJARNADÓTTIR, 2007; NOBLE, 2009).

In spite of SEA's flexibility and ability to adapt to different contexts there is a shared understanding regarding the principles and fundamentals that must guide its use in plan-making, differentiated by the extent to which each principle is applied (Noble and Nwanekezie, 2016). In this sense, according to the International Association for Impact Assessment (IAIA, 2002), a good-quality SEA process needs to be: (a) integrated - ensuring the assessment of all strategic decisions relevant to sustainable development, addressing relevant biophysical, social and economic aspects and tiered to relevant policies and projects; (b) sustainability-led - focused on key issues of sustainable development and customised to each decision making process; (c) accountable; (d) participative, informing and involving the stakeholders; and (e) iterative, providing the information early enough to influence decision making process. 
Outcomes are considered the ultimate measures of SEA added value, revealing how effective was the adaptation of SEA principles and fundaments to the context of application (ACHARIBASAM; NOBLE, 2014). An ample list of SEA outcomes are reported in the literature, such as: the acceptance of SEA validity and credibility (BUUREN; NOOTEBOOM, 2010; POLIDO; JOÃO; RAMOS, 2016; KØRNØV; THISSEN, 2000), incorporation of sustainability issues into the PPP development or PPP decision-making process (COLE; BRODERICK, 2007; ESTEVES; SOUZA, 2014; WALKER; SINCLAIR; SPALING, 2013), ownership of the PPP by the public (HAMBLIN, 1999; KØRNØV; THISSEN, 2000; SIMS, 2012), better management of (potential) conflicts and better acceptance of the final outcomes (ANDRADE; SANTOS, 2015; ESTEVES; SOUZA, 2014; REGA; BALDIZZONE, 2015).

An important aspect to the comprehension of how SEA outcomes are generated is related to their nature: according to Tetlow and Hanusch (2012), SEA outcomes can be direct and/or immediate, which facilitates its identification, or indirect and/or long-term and, therefore, more complicated to be understood. Also, according to Kidd et al. (2011), the role played by individuals and organizations combined to the approaches applied along the SEA process are strongly related to the outcomes and other effects delivered by this instrument.

Moreover, procedural aspects, objectives, guidance, approach, timing, amongst others, are often reported as key components of the different dimensions of SEA effectiveness (Fischer and Gazzola, 2006; Acharibasam and Noble, 2014) but their linkage to SEA outcomes is yet to be deeply investigated. Added to this, the body of professional literature is strongly influenced by empiric research focused on the systematic and mandatory use of SEA thus implying in a lack of knowledge regarding the specificities of SEA outcomes in non-mandatory contexts (MALVESTIO; MONTAÑO, 2019).

Therefore, this thesis aims to explore the extent to which the context may influence on SEA effectiveness based on the identification of perceived and empiric evidence of SEA outcomes and correspondent aspects that might intervene in their occurrence. The objective is to evaluate direct and indirect outcomes of SEA and, based on the Brazilian context, identify challenges and opportunities to fully extract the benefits from the use of this instrument.

Compared to others developing countries, Brazil emerge as a developing country with a fair experience with the application of SEA (TSHIBANGU; MONTAÑO, 2016) even though there is still no legal mandate for SEA in the country. In this case, although the outcomes are directly linked to the experience (and perception) of Brazilian SEA actors and institutions, it is believed that the findings and respective underlying factors reported in this dissertation may be helpful 
to other contexts. The term 'context' or 'contextual aspects' applied to SEA systems follows the proposition made by Hilding-Rydevik and Bjarnadóttir (2007), which includes the set of facts, conditions and/or circumstances that have an influence on the chosen approaches to SEA and on the outcomes of SEA implementation.

In Section 2 the objectives of this thesis are summarised, followed by (Section 3) the conceptual background to comprehend the purposes of SEA, its effectiveness and context specificities. The methodological procedures supporting the overall research, data gathering and analysis are introduced in Section 4, and deeply described along Section 5 together with the discussion of the research's outcomes. Finally, main conclusions are drawn in Section 6. 


\section{Objectives}

This thesis explores the extent to which the context may influence on SEA effectiveness, and particularly on perceived SEA outcomes.

Specific objectives of the thesis are:

- To elaborate a methodological approach based on SEA literature for a more systematic identification of SEA outcomes in decision-making processes;

- To characterize the agents and elements of the SEA system the correspondent network of actors and institutions potentially influenced by the SEA process;

- To identify the impact of SEA, both its direct influence on PPPs and other strategic decisions, and its indirect impact beyond the particular PPP for which the SEA was implemented;

- To identify contextual aspects that may hinder or ease the occurrence of SEA outcomes. 


\section{Literature review}

\subsection{Strategic Environmental Assessment: principles and conceptual background}

The National Environmental Policy Act (NEPA), enacted in 1970, is referred as the pioneer legislation devoted to the assessment of impacts of projects and strategic actions. Before its introduction, the consideration of environmental issues in decision making largely took place in an incremental manner, i.e. practice was to move away from problems rather than towards achieving objectives (MEYER; MILLER, 1984). Environmental Assessment (EA) tools emerged with a 'preventive effect' in that they have the potential to impact the way in which environmental interests are taken into account, focusing on influencing the formulation stages (FISCHER, 2003).

Almost five decades of global EA practice has resulted in the adoption of legal framework on EA tools within national governments, international organizations and Multilateral Development Agencies (MDAs) (DALAL-CLAYTON; SADLER, 2005). SEA is now widely accepted due to three relevant occurrences: (i) activities of Multilateral Development Agencies; (ii); adoption of EU Directive 2001/42/EC; and (iii) the adoption and negotiation of the SEA Protocol to the Espoo Convention (TETLOW; HANUSCH, 2012). Especially, the EU Directive 2001/42/EC and the SEA Protocol to the Espoo Convention have considerable traction in the context of SEA. Currently, it is assumed that both regulations constitute a reference point particularly within EU (DALAL-CLAYTON; SADLER, 2005).

The legal adoption of SEA has become a rule amongst high-income countries. In contrast, only a handful of low and mid-income countries have legal requirements for SEA. China (including Hong Kong), Indonesia, Taiwan and Vietnam are examples of developing countries with SEA regulations in place (VICTOR; AGAMUTHU, 2014).

In most of low and mid-income countries, SEA does not comply with specific regulations or directive-based requirements. In Brazil for example, SEA is commonly being used voluntarily or as part of loan schemes (PELLIN et al., 2011). In this latter context, MDAs are considered major players in the SEA practice, once it has become a standard tool used in the preparation and implementation of Bank-financed development projects to safeguard environmental interests and contribute to environmental governance (ALSHWAIKHAT, 2005; 
RICHARDSON; CASHMORE, 2011; CASHMORE; AXELSSON, 2013; CASHMORE et al., 2014).

The literature reports a number of definitions of SEA that reflect the different approaches applied worldwide. According to Lee and Walsh (1992, p. 126), SEA is "the environmental assessment process for PPPs which are approved earlier than the authorisation of individual projects". Therivel (2004, p. 3) defines SEA as "a process that aims to integrate environmental and sustainability considerations in strategic decision-making." Similarly, Fischer (2007, p. xiii) considers SEA as "a systematic decision support process, aiming to ensure that environmental and possibly other sustainability aspects are considered effectively in PPP making". Although definitions sometimes differ, there is a consensus that the overall concept of SEA reflects a proactive process to strengthen environmental concerns in the highest levels of decision-making (VERHEEM; TONK, 2000; HERRERA, 2007).

SEA is a process of evaluating environmental impacts at higher levels of decision-making including, but not limited to PPPs involving a legislation, a whole sector, more than one sector, an area or a region (local or national). The application of this instrument will depend on the types of PPPs and provisions adopted by the country (TETLOW; HANUSCH, 2012).

\subsection{Effectiveness and outcomes of the Strategic Environmental Assessment}

SEA effectiveness is related to its contribution to decision-making, i.e., the extent to which it influences PPPs toward the achievement of sustainability or environmental objectives, or its influence on PPP decisions (CHANCHITPRICHA; BOND, 2013). Moreover, similar to other impact assessment instruments, SEA effectiveness focuses on solving problems instead of finding irregularities (SADLER, 1996).

According to Acharibasam and Noble (2014), at the most basic level, the effectiveness of SEA is a function of its institutional requirements, assessment methodology, and to shorter or longerterm changes in PPPs. More than the effectiveness itself, there is a need to focus on SEA outcomes i.e. its added-value to decision-making (PARTIDÁRIO, 2000).

The application of SEA to higher tiers of decision-making is often associated to its potential outcomes (ALSHUWAIKHAT, 2005; LEE; WALSH, 1992; PARTIDÁRIO, 1996). SEA outcomes refer to elements of a SEA that can be identified in the decisions that were taken (RUNHAAR; DRIESSEN, 2007). For example, proactive assessment of alternatives to 
proposed or existing PPPs; analysis of cumulative and indirect effects; integration of environmental considerations into PPP-making and consideration of stakeholder interests (LEE; WALSH, 1992) and others. It is argued that the adaptability and flexibility inherent in SEA is crucial to successful application in different cultural and decision-making environments around the world (DALAL-CLAYTON; SADLER 2005; FISCHER, 2003; LOBOS; PARTIDÁRIO, 2014).

SEA outcomes can be direct or indirect in terms of their nature. According to Runhaar and Driessen (2007), direct outcomes can be identified in the decisions made including, for example, changes in the extent to which such environmental and sustainability issues are considered (THÉRIVEL; MINAS, 2002) or improvement of key features of the PPP (ACHARIBASAM; NOBLE, 2014; CONTICELLI; TONDELLI, 2013). Also, taking into account that one of the main objectives of SEA is to promote environmental issues into PPPs and secure an adequate level of environmental protection, direct outcomes are an important parameter to measure SEA effectiveness (ACHARIBASAM; NOBLE, 2014).

Direct outcomes depend on interactions between different assessment tiers, the willingness and possibility to co-ordinate these tiers and to use the lessons learned. An important factor is the time that elapses between tiers. If too much time passes, some inputs that could be made at the time of the first tier, may have become outdated when the second tier is initiated (NOOTEBOOM, 2000).

On the other hand, the indirect outcomes of SEA refer to elements of SEA that can be identified beyond the PPP or decision context (RUNHAAR; DRIESSEN, 2007). There are, for example, indirect interactions between assessment levels and planning tiers, and strategic action may have an influence on further decisions (NOOTEBOOM, 2000). Also, indirect outcomes may materialize as new ideas (e.g. time or cost savings on subsequent plans or project assessments) in the next rounds of decision-making (THÉRIVEL; MINAS, 2002).

Acharibasam and Noble (2014) have synthesised the characteristics of SEA outcomes (Table 1) according to the literature. 
Table 1- Characteristics of SEA outcomes

\begin{tabular}{ll}
\hline Direct outcomes & Indirect outcomes \\
\hline - Short(er) term & $\bullet$ Long(er) term \\
$\begin{array}{l}\text { - Materialized through PPP development or } \\
\text { decision-making }\end{array}$ & $\begin{array}{l}\text { Materialized through social, organizational, and } \\
\text { institutional learning }\end{array}$ \\
- Modification and improvement & - Benefits relate to longer-term environmental management \\
- Benefits related to specific objectives & $\bullet$ Unplanned and often implicit \\
- Planned and often explicit & Not easily identified \\
\hline
\end{tabular}

Source: Acharibasam and Noble (2014), based on: Fischer (1999), Partidário (2000), Thissen (2000), Thérivel and Minas (2002), Owens and Cowell (2006), Runhaar and Driessen (2007), Jha-Thakur et al. (2009), Noble (2009) and Van Buuren and Nooteboom (2009).

As stated by Nooteboom (2000), whenever a PPP precedes and influences a project-level decision, the strategic action and the project decision are supposed to be tiered. In fact, decisionmaking occurs in different levels, each of which may be linked with an EA and, therefore, formal linkage between the different levels of decision is highly recommended (NOOTEBOOM, 2000).

For a SEA system to be effective in terms of outcomes, there is a primary need for a strategic decision-making process suitable for 'hosting' the SEAs and the SEA processe. Although it is important to look beyond the effectiveness, there is also a great need of parsimony in relation to the instrument's expectations, once SEA is just one of several aspects to be considered by decision-makers (RUNHAAR; DRIESSEN, 2007).

The formal structure of strategic actions (their contents, responsibilities, competencies) should be defined in a way that outcomes can be highlighted (NOOTEBOOM, 2000). However, the more integrated SEA is to the planning process the harder to identify its correspondent outcomes (TETLOW; HANUSCH, 2012).

SEA literature reports different types of outcomes. For example, SEA can contribute to deepen policy learning around environmental issues and to broader changes in instituftions and governance conditions (SLUNGE; LOAYZA, 2012). It can also ensure a transparent PPPmaking process and improve planners' understanding of their PPP (THERIVEL; WALSH, 
2006). These outcomes are based on the assumption that SEA contributed to the development of closer working relationships and mutual understanding, setting the basis for learning (JHATHAKUR et al., 2009).

Public participation is an important step that enables the occurrence of SEA outcomes due to its role as a vehicle to acquire and communicate relevant information. According to Kørnøv and Thissen (2000), SEA increases the acceptance of the assessment's results and/or the decision process, as participation may lead to shared visions and a sense of ownership of the results. SEA also plays an important role in terms of inclusion of marginalized communities (WALKER; SINCLAIR; SPALING, 2013). In fact, SEA allows rural and urban poor people to provide a well-informed input in consultative meetings as well as empower them in influencing decisions (HIPONDOKA; DALAL-CLAYTON; GILS, 2016).

Arguably the assessment consists of an opportunity for active participation as SEA gives to the public an opportunity to comment on a proposal and its environmental impact before relevant decisions are taken (HAMBLIN, 1999; WALKER; SINCLAIR; SPALING, 2013; JOÃO; MCLAUCHLAN, 2014).

SEA helps managing conflicts when individual projects are proposed (NOBLE et al., 2013; SIMS, 2012) and allows the identification of critical aspects to be addressed before the implementation of a PPP (CONTICELLI; TONDELLI, 2013; POLIDO; JOÃO; RAMOS, 2016). SEA can also identify strategies to enhance positive impacts (PETERSON, 2004; CONTICELLI; TONDELLI, 2013; ACHARIBASAM; Noble, 2014), and is also recognized for its capacity to address a diverse set of issues such as climate change (LARSEN; KØRNØV, 2013; WENDE et al. 2012), biodiversity (SIMS, 2012; ESTEVES; SOUZA, 2014; SÖDERMAN; SAARELA, 2010); ecosystem services (PARTIDARIO; GOMES, 2013), sustainability (POLIDO; JOÃO; RAMOS, 2016; HIPONDOKA; DALAL-CLAYTON; GILS, 2016; NOBLE, 2009), health (DOUGLAS; CARVER; KATIKIREDDI, 2011; WRIGHT; PARRY; SCULLY, 2005), transboundary impacts (SIMS, 2012; MARSDEN, 2011) and cumulative effects (NOBLE, 2009).

Through the assessment of impacts, SEA contributes to improve the PPP's development and/or its implementation (ACHARIBASAM; NOBLE, 2014) mainly due to its ability to identify and improve key aspects of the PPP (TETLOW; HANUSCH, 2012), which can led to significant changes such as the revision of PPPs objectives or the adoption of new alternatives for the PPP (THERIVEL, 2006). 
SEA can also be regarded as a source of valuable information as it generates primary data (HIPONDOKA; DALAL-CLAYTON; GILS, 2016) and provides accessible information (e.g. baseline data, thresholds, etc.) for the use in subsequent PPP processes, monitoring programmes or project-based impact assessments (SHEPHERD; ORTOLANO, 1996; SIMS, 2012; ACHARIBASAM; NOBLE, 2014). Also, SEA can help to increase richness of information and creativity reflected in the alternatives to PPP strategies, considering its capacity to assimilate the different point of view and knowledge of a multiple range of actors (KØRNØV; THISSEN, 2000; SIMS, 2012).

Concerning the involvement of the different actors in the assessment process, SEA ensures better communication and co-operation between authorities, individuals, other institutions and organisations (SIMS, 2012; FISCHER et al., 2009). It has also been reported that SEA has contributed to an improved communication and a more transparent relationship between governments and civil society, which also may lead to improved accountability. Further, SEA can deepen the interaction between environmental advocates and other actors at different levels (REGA; BONIFAZI, 2014). It is concluded that SEA creates 'an arena for mediation between strategic partners, where knowledge is shaped by negotiations and tensions between positions, and by the need to secure a working consensus' (KIRCHHOFF et al., 2011).

Finally, it is reported that SEA identifies or stimulates new research directions or needs (ACHARIBASAM; NOBLE, 2014). Innovation through SEA is little discussed in the literature so far, though it is accepted that SEA can support innovative contributions to the decisionmaking processes whenever the focus is shifted from legal compliance to a reflexive, consensus-building and fact-finding SEA process (ACHARIBASAM; NOBLE, 2014; BROWN; THERIVEL 2000).

\subsection{Strategic Environmental Assessment in Brazil: contextual aspects}

There is no legal mandate for SEA in Brazil, which implies in several constraints to the implementation of this tool in policy and plan-making. There has been several institutional and legislative initiatives both within federal and state levels to introduce SEA into the environmental legislation (OPPERMANN, 2012). However, none of these initiatives resulted in any legal requirements and formal provisions for SEA. Therefore, SEA practice is usually referred as 'disperse' and 'unconsolidated' (GALLARDO; BOND, 2011; MALVESTIO; 
MONTAÑO, 2019). During the last decade, there has been a considerable debate regarding the pros and cons of an eventual mandatory SEA process and its formal adoption.

Nevertheless, SEA has been applied in Brazil for several years, mostly as part of MDAs activities to safeguard environmental interests (PELLIN et al., 2011). SEA has also been applied in voluntary initiatives of private entrepreneurs and environmental agencies in order to anticipate potentials conflicts expected at project level (MALVESTIO; MONTAÑO, 2013).

Lack of formal requirements makes difficult to provide an overview of planning leading to conflict associated the use of environmental resources and cumulative impacts (TEIXEIRA, 2008), as well as divergent conceptions and views (OPPERMANN; MONTAÑO, 2011). The result is a system of SEA that is diverse, based on a range of frameworks, and not well understood (MALVESTIO; MONTAÑO, 2013).

Brazilian SEA literature gives consideration to the country's SEA practice (Box 1). Generally, most of studies refer to the absence of SEA regulations as the principal characteristic of Brazilian SEA system. SEA cannot be considered legally accepted as its application is conducted on a voluntary basis. There is a lack of regulations on the definition of contextual factors such as where and how SEA should be applied (MONTAÑO et al., 2011).

The list of Brazilian SEA reveals that applications refer to three different situations: (i) SEA is requested by the state or federal governments, sometimes through their secretariats and environmental agencies; (ii) SEA is requested by MDAs; (iii) SEA is requested by the private initiative and society (MALVESTIO; MONTAÑO, 2013). Special regard is addressed to the important role played by MDAs which use this tool to safeguard environmental interests and contribute to environmental governance (RICHARDSON; CASHMORE, 2011; CASHMORE et al., 2014). In developing countries, SEA is largely driven by these agencies (TSHIBANGU; MONTAÑO, 2016).

In Brazil, some SEAs are applied to facilitate the approval of project EIA. In other words, initiatives emerged from the process of EIA project approval. This was the case of the SEA applied to São Paulo Metropolitan Ringroad Programme. To obtain the project approval, proponents resorted to SEA to test the hypothesis of self-standing sections project (SÁNCHEZ; SILVA-SÁNCHEZ, 2008). This case illustrates the strong influence of environmental license culture. SEAs are not always applied as a means to insert the environmental dimension into the decision-making process. It is seems that mostly the primary intent is to obtain the PPP approval. 
SEA in Brazil is also characterized by the weak link between the assessment findings and decision-making. In fact, SEA suffers from the absence of a clear decision-making context (MARGATO; SÁNCHEZ, 2014). Generally, the process starts with an already proposed strategic action. Then its impacts are assessed, resulting in raising recommendations for mitigation and compensation or improvements. In such context, there is little influence of SEA on the PPP implementation (TEIXEIRA, 2008; MALVESTIO; MONTAÑO, 2013).

In Brazil, SEAs are also applied to large projects. Mostly actions are named "projects", but contain components of high level initiatives (MALVESTIO; MONTAÑO, 2013). However, decisions related to the location and economic alternative of large projects had already been taken prior to the SEA application or even before the conduction of the project EIA (Silva et al., 2014). Often SEA aims are limited to complement project EIA or provide guidance (TEIXEIRA, 2008).

Public participation was found limited to a tick-box exercise (MALVESTIO; MONTAÑO, 2013; MARGATO; SÁNCHEZ, 2014). There is poor involvement of stakeholders as the participation is restricted to public hearings (MALVESTIO; MONTAÑO, 2013). According to the World Bank, the challenge of public involvement in low and mid income countries also lies in the interests of different stakeholders, each wanting to increase their gains instead of adopting $\mathrm{a}$ «win-win» posture. Moreover, some public do not feel sufficiently involved in the assessment process because their financial power is limited (World Bank, 2011).

The lack of data is also a characteristic of the Brazilian SEA context. According to Alshuwaikhat (2005), this deficiency observed commonly in developing countries affects the anticipation and monitoring of environmental effects. It is acknowledged that, data can have relevant repercussions on SEA because they help define what SEA is about. However, even when data are available, there is a need to clearly specify what data to use and why (JOÃO, 2007).

Box 1 summarizes the contextual factors (presented above) according to the literature. 
Box 1. Brazilian contextual factors according to the literature

- Lack of SEA guidelines and legislation.

- SEA applications refer to three different situations: (i) SEAs requested by state or federal governments; (ii) SEAs requested by MDAs; (iii) SEAs requested by private initiative and society.

- Influence of the SEA prevailing view as a tool applied to obtain the approval of funding or to facilitate the approval of projects EIA.

- Strong influence of environmental license culture.

- Influence of EIA on SEA practice.

- Weak link between SEA and decision-making.

- SEAs applied to large projects.

- Limited public participation.

- Lack of available data on social and environmental aspects.

Source: Several authors including, but not limited to, Andrade and Santos (2015), Malvestio and Montaño (2013), Sánchez and Silva-Sánchez (2008), Silva et al. (2014).

\subsection{SEA outcomes in Brazil}

Brazilian SEA literature provides an interesting overview of SEA outcomes and their correspondent contextual factors. SEA of the São Paulo Metropolitan Ringroad Programme has induced the project reformulation considering multi-sectorial integrated actions together (SÁNCHEZ; SILVA-SÁNCHEZ, 2008). Considering the lack of formal requirements for SEA in São Paulo State and the difficulties in obtaining the permissions to the São Paulo Metropolitan Ringroad project, SEA emerged as a path to ease the approval. The assessment tested the hypothesis of independent, self-standing, sections of the project. This hypothesis was implemented shifting the former project to a programme involving a set of "integrated multisectorial actions". It is to be noted that despite the decision to build the highway had already been taken some years before the SEA conduction, it still found some room to influence on decision-making. 
Another outcome verified includes the use of SEA findings beyond the PPP or decision context. Recommendations of the SEA applied to the São Paulo Metropolitan Ringroad Programme were considered in subsequent EIAs (SÁNCHEZ; SILVA-SÁNCHEZ, 2008). SEA applied to Corumbá Mining and Industrial District contributed in an important way to guide planning and complex management, and sustainable development of the region (SILVA et al., 2014). Similarly, SEA of the Multimodal Transportation and Industrial Development in the Cocoa Region has also influenced the process of environmental licensing (mandatory procedure in Brazil) of ventures with high polluting potential. Looking at the three SEAs, it can be said that they are comparable in the sense that they were applied to anticipate future conflicts and ease EIA approval (SÁNCHEZ; SILVA-SÁNCHEZ, 2008; SILVA et al., 2014).

Regarding the SEA of the Program for Tourism Development in the North Coast, restricted public participation and lack of coordination and synergy between the federal and state actions were the major constraints. However, the SEA could provide information for formulating a methodological procedure for SEA adopted in other regions in accordance with the commitments with the Inter-American Development Bank (IADB) (SILVA et al., 2014). Additionally, this SEA was an opportunity to improve communication between stakeholders and enhance institutional learning through the Ministry of Tourism's commitment and involvement in the participation process (SILVA et al., 2014). Table 2 summarizes above SEA outcomes identified in the literature.

Table 2 - Outcomes of SEA on strategic decisions and related contextual factors (follows)

\begin{tabular}{|c|c|c|}
\hline SEA & Outcomes identified & Contextual factors \\
\hline $\begin{array}{l}\text { São Paulo } \\
\text { Metropolitan } \\
\text { Ringroad Programme }\end{array}$ & $\begin{array}{l}\text { - Project reformulation considering multi- } \\
\text { sectorial integrated actions together } \\
\text { - Consideration of each major section of the } \\
\text { Ring Road as an independent project } \\
\text { - Prioritization of South section construction, in } \\
\text { order to link the end of the west section to the } \\
\text { major highways leading to the Santos seaport } \\
\text { - Consideration of SEA recommendations in } \\
\text { subsequent EIAs, including definition of spatial } \\
\text { boundaries of the project subject to EIA; issues } \\
\text { to be addressed in the EIAs; selection of } \\
\text { alternative corridors. }\end{array}$ & $\begin{array}{l}\text { - SEA requested to facilitate project } \\
\text { approval } \\
\text { - The decision to build the highway } \\
\text { had already been taken some years } \\
\text { before the SEA conduction } \\
\text { - SEA focused on justification of } \\
\text { certain decisions taken to facilitate } \\
\text { EIA approval. }\end{array}$ \\
\hline
\end{tabular}


Corumbá Mining and - Involvement of mining companies operating in Industrial District the region

- Notification of alternatives to consider to decision makers

- Use of SEA as a guiding reference document for planning and complex management

- Use of SEA as reference for the sustainable development of the region.
- SEA requested to comply with the safeguard policies of Multilateral Development Agencies

- Applications requested to anticipate EIA conflicts, facilitating its approval.
Program for Tourism - Use of SEA to guide the formulation of a Development in the methodological procedure adopted in other North Coast regions in accordance with the commitments with the IADB
Restricted public participation and lack of coordination and synergy between the federal and state actions.

- Enhancement of institutional learning.

\begin{tabular}{|c|c|}
\hline $\begin{array}{l}\text { Multimodal } \\
\text { Transportation and } \\
\text { Industrial } \\
\text { Development in the } \\
\text { Cocoa Region }\end{array}$ & $\begin{array}{l}\text { Consideration of SEA guidelines and - Conflicts between biodiversity } \\
\text { recommendations during the process of conservation and tourism activities. } \\
\text { environmental licensing (mandatory procedure } \\
\text { in Brazil) of ventures with high polluting } \\
\text { potential. }\end{array}$ \\
\hline
\end{tabular}

\begin{tabular}{|c|c|c|}
\hline $\begin{array}{l}\text { Hydropower } \\
\text { Generation in Minas } \\
\text { Gerais }\end{array}$ & Positive learning through SEA practice. & $\begin{array}{l}\text { - SEA required to support decision- } \\
\text { making on hydroelectric expansion } \\
\text { in the state of Minas Gerais. }\end{array}$ \\
\hline
\end{tabular}

\begin{tabular}{ll}
\hline Expansion of Positive learning through SEA practice. & SEA required to promote \\
Eucalyptus and & sustainable decision on the \\
Sugarcane Plantations & $\begin{array}{l}\text { expansion of eucalyptus forests and } \\
\text { biofuels. }\end{array}$
\end{tabular}

Chopim river basin. Positive learning through SEA practice. - SEA required to serve as a reference for the assessment of power plants to be implemented in the watershed.

Sub-basin of the Rio Positive learning through SEA practice.

- SEA required to assess potential Verde conflicts and impacts related to the implementation of hydroelectric activities in the river basin.

Turvo river basin Positive learning through SEA practice. - SEA required to support hydroelectric activities.

Sources : Silva et al. (2014); Sánchez and Silva-Sánchez (2008); Malvestio and Montaño (2013); Montaño et al. (2013).

Literature on SEA in Brazil also reports positive learning through SEA practice. Montaño et al. (2013) noted a slow, but constant increase in the procedural performance of Brazilian SEAs. 
This is consistent with information reported in SEA applied to the Multimodal Transportation and Industrial Development in the Cocoa Region. The assessment report refers to several SEAs including those applied to Corumbá Mining and Industrial District, and Açú Industrial and Harbor Complex as reference practices to evaluate investment strategies related to the mining and industrial sector as well as the transport logistics sector (LIMA, 2008). According to Unalan and Cowell (2009), by the second application actors involved in the SEA process had deeper knowledge of the tool from previous experience. There is a need for improved follow-through and follow-up on SEA to ensure learning through its practice (ACHARIBASAM; NOBLE, 2014). 


\section{Methods}

It is important to clarify the meaning of terms used herein. 'Actor', 'participant' (or their variations 'key-actor' or 'key-participant') make reference to individuals who formally represent an institution with an official affiliation and known location/contact. In the same way, the term 'institution' refers to the organisation to which the actor is affiliated.

'Outcome' is referred herein as the perceived influence of SEA on the content of a strategic action, on decision-making, on the participants and/or organisations taking part in the planning process, both in the short and long term (Runhaar and Driessen, 2007).

Also, in this thesis, the term 'context' or 'contextual aspects' applied to SEA systems follows the proposition made by Hilding-Rydevik and Bjarnadóttir (2007), which includes the set of facts, conditions and/or circumstances that have an influence on the chosen approaches to SEA and on the outcomes of SEA implementation.

Figure 1 illustrates the methodological design of thesis. It is important to note that methods of this tesis have a degree of subjectivity even tough procedures are based on literature. 
Figure 1 - Methodological flow

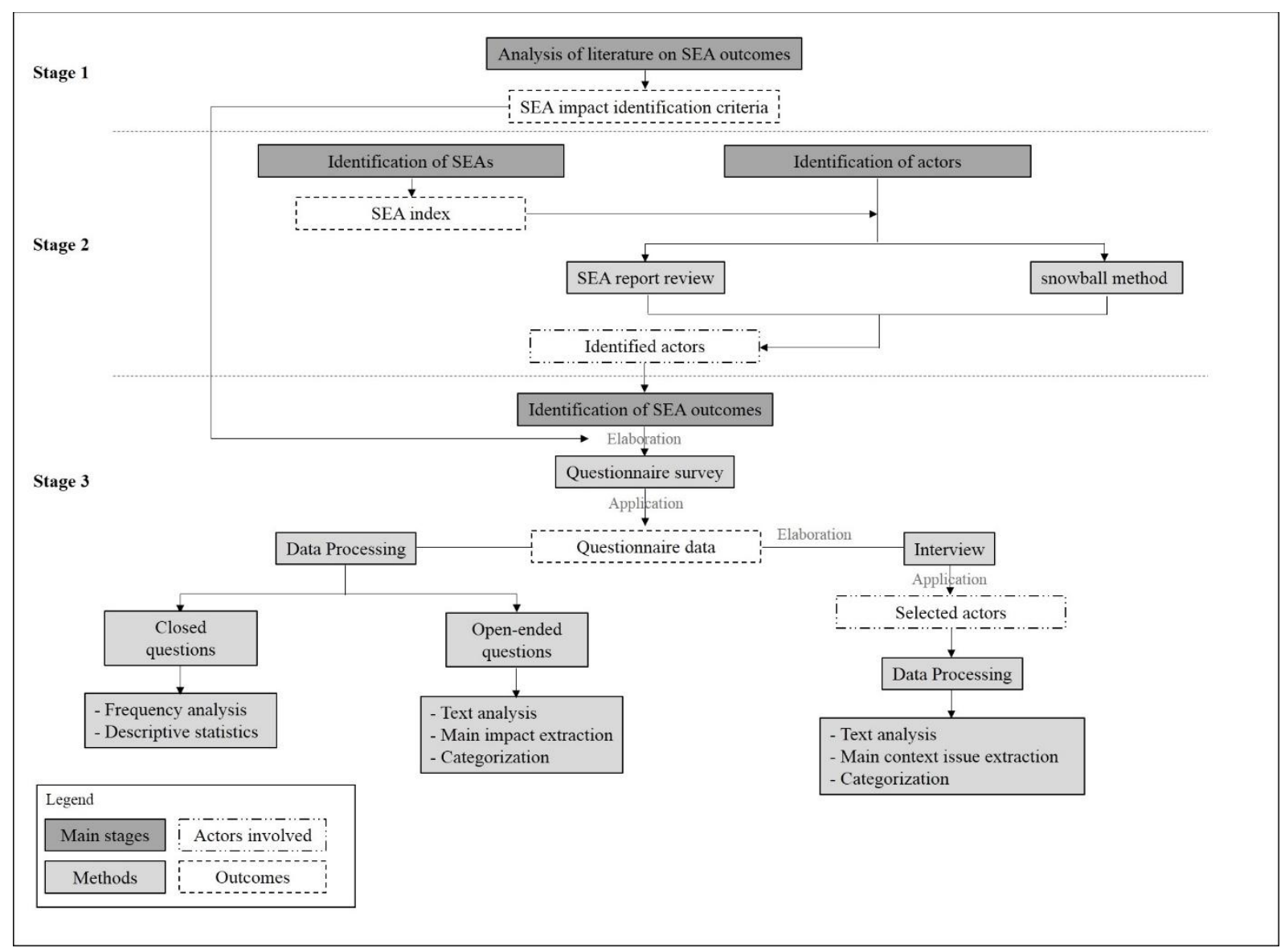

Source: self-elaboration

The methodological approach underlying in this thesis is based on SEA literature and consists of the following steps:

4.1 Methodological approach based on SEA literature for a more systematic identification of SEA outcomes in decision-making processes

One of the goals of a literature review is to identify the current state of knowledge of a specific topic (MATTHEWS; ROSS, 2010). In this thesis, a systematic review was conducted according to the methodological approach presented by Torgeson (2003), which allows the identification of all the available evidence regarding a given subject. 
The literature review was based on a systematic analysis focusing on SEA outcomes. A first set of 284 papers was identified, after searching in Web of Science and Scopus international databases, combined with a national database (Scielo). Searching expressions included combinations of the following keywords: 'Strategic Environmental Assessment', 'outcome', 'impact', 'effect', 'efficacy', 'influence' and 'benefit'. Screening procedures included reading the title, abstract, introduction and conclusions, thus leading to 63 papers published until September 2018, from which a number of 269 SEA outcomes were then identified and grouped according to a 'coding-up' process (BERG, 2001). Throughout a series of iterations the similar outcomes were grouped and regrouped (see, for example, CORBIN; STRAUSS, 2008) according to their perceived characteristics or attributes. Finally, a total of 98 SEA outcomes have emerged from this procedure.

The high number of outcomes makes it very difficult to conduct the following stages of this thesis. Especially in the upcoming questionnaire phase, the respondent has to identify the occurrence of each outcome. As a result, it seemed more coherent to replace the long list of outcomes with the IAIA performance criteria (See IAIA, 2002) which endorse an international independent institution and are widely used to examine SEA effectiveness in different contexts (NOBLE, 2003; RETIEF, 2007).

A workshop involving 10 SEA specialists (practitioners and scholars with a minimum of 180 hours of formal training in SEA) has allowed to confront the SEA outcomes reported in the literature with the IAIA's SEA principles/performance criteria. Each outcome was then linked to their corresponding IAIA performance criteria, thus allowing to verify the extent to which they are convergent to each other. Outcomes that could not be linked to none of the criteria were included as a new criterion in a new category of principles. The final list of 23 criteria is presented in the Results section.

\subsection{Characterization of actors and institutions potentially influenced by the SEA process}

Throughout this thesis, SEA envelops different types of strategic assessment including Strategic Environmental Reassessment, Regional Environmental Assessment (EA), Programmatic Environmental (and social) Assessment, Integrated Environmental Assessment and Strategic Study of Public Policy, Strategic Environmental Planning (ANNANDALE et al., 2001; LOAYZA, 2012). Although these EA adopt different approaches such as impact-centered and 
policy-centered (LOAYZA, 2012), their scope includes more than environmental effects caused by a particular project or activity.

Due to the absence of an organized SEA database and given the lack of SEA legislation in Brazil with explicitly identified actors and their roles, a first step was to index the existent SEAs already applied in the country. SEAs were searched using web engine searches via Google, MDAs online databases, contact with SEA practitioners and institutions (planning agencies, environmental authorities, MDAs) representatives by e-mail or telephone, which allowed for the identification of 68 SEAs conducted from 1997 to 2018 (Annex 1). The second step was to identify the actors and institutions involved in the assessment or potentially impacted by the instrument in order to adjust the process of characterizing SEA outcomes (ACHARIBASAM; NOBLE, 2014; PETERSON, 2004).

Data gathering was accomplished through qualitative content analysis following the methodological guidelines of Krippendorff (2003). Neuendorf (2002, p1) defined a content analysis as "the systematic, objective (...) analysis of message characteristics". This methodology can be used to collect data from documents (NEUENDORF, 2002), and make replicable and valid inferences from specified characteristics within text (KRIPPENDORFF, 2003). Although content analysis has some disadvantages such as the need of sufficient human resources to be committed to it when dealing with large volumes of textual data, this methodology has explicit procedures and quality control checks (GAO, 1996).

Actors and institutions involved in the SEAs were identified through a content analysis of SEA reports. Whenever available, lists of participants of public meetings were used as they provide names, affiliated institutions and professional contacts of stakeholders. Subsequently, each person was contacted by e-mail with an invitation to respond to a questionnaire and to inform about other actors (individuals and/or institutions) who would be of interest to contact, considering the research's objectives. These steps constitute the snowball technique as described by Alameddine et al. (2011) and Scolozzi et al. (2012). This technique was ended when the names started repeating themselves. The process took place from April to November 2016.

It is important to highlight the uncertainty arising from the use of SEA in a non-mandatory context where actors could be affiliated to institutions that might not be directly related to evaluation process (BASTOS, 2015). 


\subsection{Identification of SEA (direct and indirect) outcomes}

The identification of outcomes was based on the application of questionnaires and targeted interviews, as described.

(i) Questionnaire survey

In order to identify outcomes perceived by participants and due to the exploratory nature of this research a questionnaire survey was directed to the actors involved in the SEA processes including the public, consultants, representatives of environmental agencies and delegates of the proponent institutions. The questionnaire survey is likely the most common way of collecting data from research participants (MATTHEWS; ROSS, 2010) and is also frequently reported in SEA research (see BRAGAGNOLO et al., 2012; JOÃO; MCLAUCHLAN, 2014; REGA; BALDIZZONE, 2015; THÉRIVEL; MINAS, 2002).

The questionnaire's application was conducted by e-mail between 17 May 2017 and 31 July 2017 and included all of the 746 actors identified (326 consultants, 73 proponents, 327 public representatives, 11 environmental agencies representatives, 5 MDAs representatives, and 4 representatives whose institutions could not be identified). A total of 257 actors could not be reached as their e-mail accounts were no longer active or incorrectly spelled, which may be attributed to the fact that most e-mails addresses are institutional and respective actors are no longer working at the same institution.

Three follow-up emails were sent to the identified SEA actors to overcome a possible low response rate limitation. Finally, 88 questionnaires were filled out, which seemed more promising than reported to similar researches: Bragagnolo et al. (2012) have interviewed 12 experts; Polido et al. (2016) worked with 16 questionnaires; and Peterson (2004) reported 26 responses to the questionnaires.

To allow comparable answers, the questionnaire was developed using a majority of closedended questions (MATTHEWS; ROSS, 2010; REA; PARKER, 2014). Questions were numbered and grouped by topic into 7 sections, as advised by Lietz (2010). At least, one optional open-ended final question was added to each section in order to avoid a manipulative and repetitious questionnaire, allowing the respondents to answer the question in their own way by adding information to what was previously stated (SOUZA, 2014). For the closed-ended 
questions, only nominal responses scales were used with five response options according to a Likert scale, including: (i) strongly disagree; (ii) partially disagree; (iii) neither agree or disagree; (iv) partially agree; and (v) strongly agree (GILES, 2013). The questionnaire was developed to be easily and quickly understood, but at the same time, detailed and relevant for gathering the needed data. Further, a pre-test was conducted to estimate the time for its completion (REA; PARKER, 2014), and to identify issues of validity as well as other possible problems with the questionnaire, as recommended by Matthews and Ross (2010).

All participants have freely consented to fill the questionnaire (RITCHIE; LEWIS, 2003). Moreover, the questionnaire clearly mentioned that the answers should be based on the respondents' experience, expertise and knowledge.

The data retrieved from the questionnaires was analyzed (i) based on frequencies of each answer; and (ii) for the open-ended questions a qualitative content analysis was performed, when possible, as applied in similar studies (e.g., ACHARIBASAM; NOBLE, 2014; THÉRIVEL; MINAS, 2002). Qualitative content analysis aimed to systematize information reported in open-ended questions, trying to eliminate evaluator subjectivity and interpretation (NEUENDORF, 2002; ROUDGARMI, 2011).

When possible, a coding system was used (ELO; KYNGÄS, 2007) through an iterative procedure, based on a case-by-case approach. The method enables valid and replicable inferences from response texts (KRIPPENDORFF, 2003). Content analysis limitations are commonly related to the credibility, authenticity, representativeness and availability of the documents analyzed (BRYMAN, 2012). However, these limitations are minimized as these are views, experiences and perspectives of the SEA actors. A code was given to each respondent/questionnaire with no specific order. In order to ensure respondents anonymity, codes were used throughout the thesis when necessary. The full questionnaire is presented in Annex 3.

(ii) Interview

An interview is a data collection method which facilitates direct communication and enables the interviewer to elicit information using questions and interactive dialogue (BAUER; GASKELL, 2002; BERG, 2001; MATTHEWS; ROSS, 2010). The interview key feature consists of direct contact between the interviewer and the participant (YIN, 2011). As a mean 
of gathering social data it has been recognized as a means of collecting interviewee's opinions, experiences and characteristics for much of the last century (MATTHEWS; ROSS, 2010).

Participants are those who previously responded to the questionnaire and accepted to be interviewees. In the interview, they were asked to provide context factors associated to each question of the questionnaire. Context refers to the circumstances or facts that have an impact on SEA, and also the conditions that have an impact on the outcomes of SEA implementation. This includes the chosen objectives or goals of SEA, the regulatory or institutional environment, process expectations, participants in the assessment, and the organizations involved (HILDING-RYDEVIK; BJARNADÓTTIR, 2007).

Information was gathered by telephone or online interviews being the only viable method owing to geographic locations (BERG, 2001). This thesis builds on the experience gained by interviewees in taking part of SEA processes. Therefore, open semi-structured interviews were preferred to allow the participant to answer the questions or discuss the topic in their own way using their own words (BERG, 2001; MATTHEWS; ROSS, 2010).

A pilot-test has been conducted before the main research data gathering takes place in order to try out and amended, if necessary, question wording, interviewee understanding and data collection procedures (MATTHEWS; ROSS, 2010). Main research interviews were conducted between 28 January 2018 and 25 February 2018 with nine interviewees including 6 consultants, 2 proponents and 1 representative of an environmental agency covering a range of 35 (out of 68) SEAs prepared in the country by the time of research.

Box 2. Actors' roles and related SEA (follows)

\begin{tabular}{lllc}
\hline Actor & Role & SEA & 02 \\
\hline Actor 1 & $\begin{array}{l}\text { Government } \\
\text { (environmental agency) }\end{array}$ & 23 and 25 & $\begin{array}{c}\text { Expertise in the country } \\
\text { (number of SEAs) }\end{array}$ \\
Actor 2 & Consultant & $15,30,31,45$ and 63 & 05 \\
Actor 3 & Consultant & $11,15,54,57,58$ and 59 & 06 \\
Actor 4 & Consultant & 39,45 and 65 & 03 \\
Actor 5 & Consultant & $38,39,45$ and 65 & 04 \\
Actor 6 & Consultant & $1,12,22,23,34,35,39,52$ and 53 & 09
\end{tabular}




\begin{tabular}{lllc}
\hline Actor & Role & SEA & $\begin{array}{c}\text { Expertise in the country } \\
\text { (number of SEAs) }\end{array}$ \\
\hline Actor 7 & Consultant & 55 and 57 & 02 \\
Actor 8 & Proponent & 22 & 14 \\
Actor 9 & Proponent & $28,29,30,31,32,41,42,47,48$, \\
& & $54,55,56,57$ and 66 \\
\hline
\end{tabular}

The interviews were carried out in an evolving and opportunistic way in order to maximize researcher understanding and depth of knowledge, in contrast to an identical suite of questions posed to a range of interviewees, as usually observed in qualitative social science research (SEIDMAN, 2006). When designing the semi-structured interview, caution was taken to ensure that the approach enables interviewees to reply in their own way using their own words and is flexible and adaptable to different respondents, but ensures that the same issues of the research topic are covered with each participant (MATTHEWS; ROSS, 2010).

Interviews provided an opportunity to clarify the questionnaire's responses and also to deepen some aspects related to SEA outcomes. Interviewee's responses were referred to by a code depicting the organizational affiliation of the respondent, in order to secure anonymity (MATTHEWS; ROSS, 2010). Regarding ethical issues, care has been taken to ensure that (i) all information data given would be considered confidential and could not be accessed by others; (ii) thesis and research papers would not include data that could lead to the identification of interviewees; and (iii) participants would not suffer ongoing distress due to the interview (MATTHEWS; ROSS, 2010; RITCHIE; LEWIS, 2003). All respondents agreed to be interviewed by filling a written consent form.

Interviews were recorded and transcribed (BAUER; GASKELL, 2002; SEIDMAN, 2006). The data gathered was then analyzed through a qualitative content approach based on the research questions. We adopted the method approach used to analyze open-ended question of the questionnaire. 


\section{Results and Discussion}

\subsection{Methodological approach based on SEA literature for a systematic identification of} SEA outcomes in decision-making processes

The literature suggests that the SEA process has the potential to contribute to improve the decision-making in various ways (PARTIDÁRIO, 2007). The IAIA provides a set of performance criteria to guide on "how to build effective new SEA processes and evaluate the effectiveness of existing SEA processes" (IAIA, 2002). Here, IAIA performance criteria were linked to 92 out of 98 SEA outcomes identified in the literature (Annex 2, Figure 2 and Table $3)$.

Figure 2 - Linkage of outcomes and IAIA performance criteria

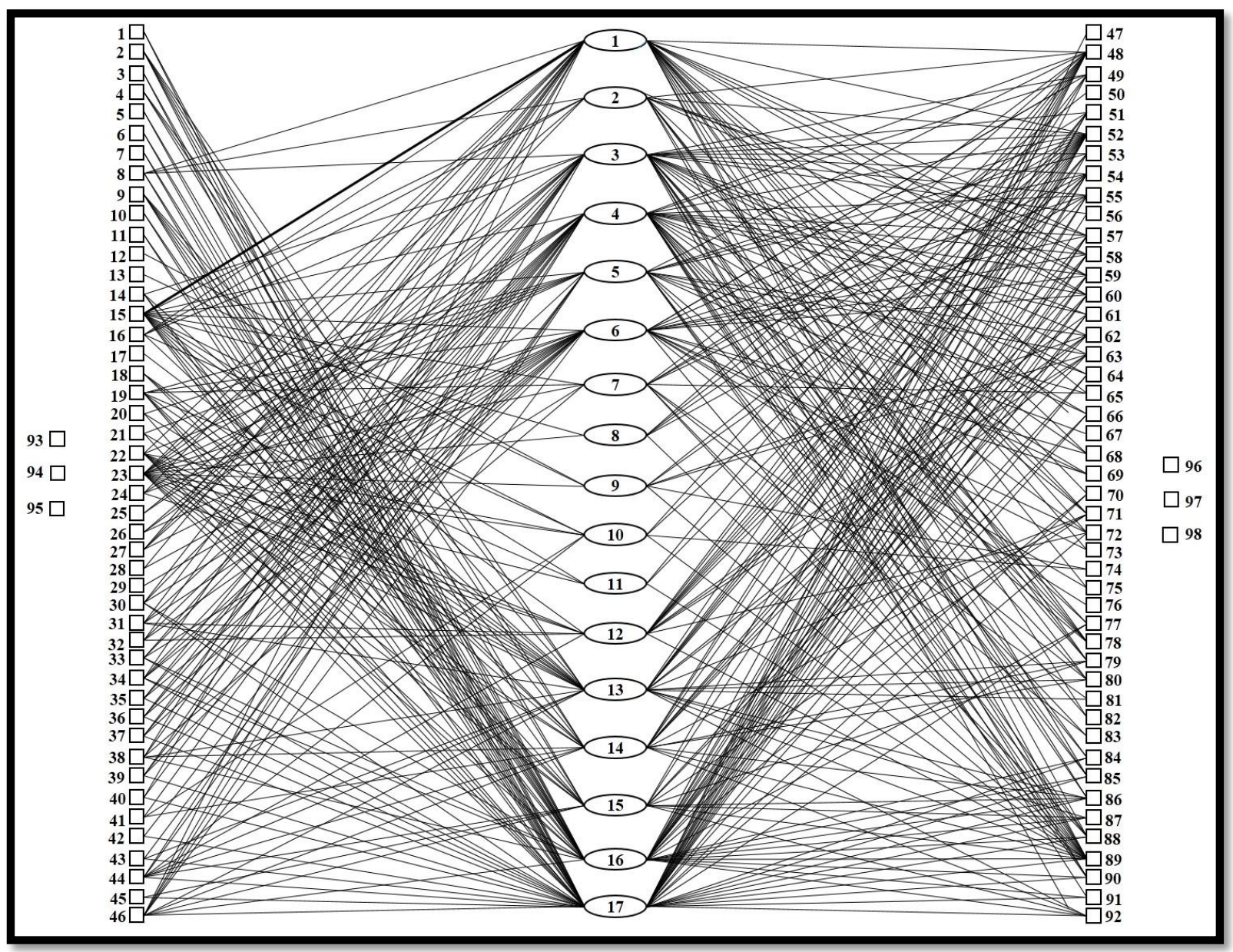


Table 3 - Linking of IAIA performance criteria and SEA outcomes

\begin{tabular}{|c|c|c|c|c|}
\hline IAIA criteria & & $\begin{array}{c}\text { SEA outcomes identified in } \\
\text { the literature }\end{array}$ & $\begin{array}{l}\text { Number of } \\
\text { outcomes }\end{array}$ & $\begin{array}{c}\text { Percentage } \\
(\%)\end{array}$ \\
\hline \multirow[t]{3}{*}{ 1. Is integrated } & $1 \mathrm{a}$ & $\begin{array}{c}(8)(15)(16)(22)(23)(24) \\
(27)(28)(30)(31)(32)(34) \\
(38)(40)(46)(48)(52)(57) \\
(58)(59)(60)(35)(66)(68) \\
(70)(71)(72)(73)(75)(78) \\
(79)(82)(85)(88)(89)\end{array}$ & 35 & 38 \\
\hline & $1 \mathrm{~b}$ & $\begin{array}{c}(8)(15)(16)(23)(27)(28) \\
(48)(52)(57)(59)(60)(71) \\
(78)(79)(80)(86)(89)\end{array}$ & 17 & 18,5 \\
\hline & $1 \mathrm{c}$ & $\begin{array}{c}(8)(14)(16)(23)(25)(26) \\
(27)(30)(33)(35)(36)(37) \\
(38)(39)(46)(49)(51)(52) \\
(53)(54)(55)(56)(61)(62) \\
(63)(68)(64)(68)(71)(77) \\
(78)(79)(84)(85)(86)(89) \\
(90)(92)\end{array}$ & 38 & 36,8 \\
\hline 2. Is sustainability-led & $2 \mathrm{a}$ & $\begin{array}{c}(15)(23)(24)(25)(26)(31) \\
(32)(33)(34)(35)(36)(37) \\
(39)(40)(41)(44)(46)(48) \\
(49)(52)(55)(57)(58)(59) \\
(60)(61)(64)(66)(69)(72) \\
(77)(78)(80)(82)(84)(85) \\
(88)(89)(90)(91)\end{array}$ & 40 & 41,3 \\
\hline \multirow[t]{4}{*}{ 3. Is focused } & $3 \mathrm{a}$ & $\begin{array}{c}(15)(19)(20)(21)(22)(23) \\
(34)(42)(43)(44)(46)(48) \\
(52)(53)(54)(62)(63)(65) \\
(67)(69)(78)(83)(88)(89) \\
(90)\end{array}$ & 25 & 26,8 \\
\hline & $3 b$ & $\begin{array}{c}(15)(19)(23)(24)(26)(27) \\
(28)(29)(30)(31)(32)(34) \\
(35)(36)(37)(39)(46)(48) \\
(49)(52)(55)(57)(58)(59) \\
(60)(68)(69)(72)(73)(75) \\
(76)(80)(89)\end{array}$ & 33 & 27,2 \\
\hline & $3 c$ & $\begin{array}{c}(15)(19)(23)(33)(38)(48) \\
(51)(52)(54)(65)(81)(83) \\
(88)(89)\end{array}$ & 14 & 15,2 \\
\hline & $3 \mathrm{~d}$ & $\begin{array}{c}(15)(23)(48)(50)(52)(55) \\
(89)\end{array}$ & 8 & 8,7 \\
\hline \multirow[t]{2}{*}{ 4. Is accountable } & $4 a$ & $\begin{array}{c}(12)(13)(23)(52)(54)(62) \\
(63)(74)(89)\end{array}$ & 9 & 9,8 \\
\hline & $4 \mathrm{~b}$ & $\begin{array}{c}(15)(16)(22)(23)(41)(44) \\
(48)(52) 74)(89)\end{array}$ & 10 & 10,9 \\
\hline
\end{tabular}




\begin{tabular}{|c|c|c|c|c|}
\hline IAIA criteria & & $\begin{array}{l}\text { SEA outcomes identified in } \\
\text { the literature }\end{array}$ & $\begin{array}{c}\text { Number of } \\
\text { outcomes }\end{array}$ & $\begin{array}{c}\text { Percentage } \\
(\%)\end{array}$ \\
\hline & $4 \mathrm{c}$ & $(15)(19)(23)(48)(52)(89)$ & 6 & 6,5 \\
\hline & $4 d$ & $\begin{array}{c}(15)(22)(23)(24)(31)(32) \\
(44)(48)(49)(51)(52)(53) \\
(54)(55)(61)(62)(63)(72) \\
(89)\end{array}$ & 19 & 20,7 \\
\hline \multirow[t]{3}{*}{ 5. Is participative } & $5 \mathrm{a}$ & $\begin{array}{c}(2)(4)(9)(14)(15)(17)(18) \\
(19)(20)(21)(22)(23)(31) \\
(38)(43)(44)(46)(48)(51) \\
(52)(53)(54)(62)(63)(71) \\
(79)(80)(81)(86)(87)(89) \\
(92)\end{array}$ & 32 & 34,8 \\
\hline & $5 b$ & $\begin{array}{l}(2)(4)(9)(15)(16)(18)(22) \\
(23)(38)(41)(44)(46)(48) \\
(49)(52)(57)(58)(59)(60) \\
(71)(79)(80)(86)(89)(92)\end{array}$ & 25 & 27,2 \\
\hline & $5 \mathrm{c}$ & $\begin{array}{c}(2)(4)(9)(15)(18)(19)(22) \\
(23)(44)(45)(46)(48)(52) \\
(62)(63)(71)(79)(86)(87) \\
(89)(92)\end{array}$ & 21 & 22,8 \\
\hline \multirow[t]{2}{*}{ 6. Is iterative } & $6 a$ & $\begin{array}{c}(1)(2)(3)(5)(6)(7)(8)(9) \\
(10)(11)(14)(15)(19)(22) \\
(23)(30)(33)(34)(38)(46) \\
(48)(51)(52)(54)(55)(57) \\
(58)(59)(64)(66)(70)(77) \\
(84)(85)(86)(87)(88)(89) \\
(90)(91)(92)\end{array}$ & 43 & 46,7 \\
\hline & $6 b$ & $\begin{array}{c}(1)(2)(3)(5)(6)(7)(8)(9) \\
(11)(10)(14)(15)(19)(20) \\
(21)(22)(23)(30)(33)(34) \\
(35)(36)(37)(39)(40)(42) \\
(43)(44)(45)(46)(47)(48) \\
(49)(51)(52)(53)(54)(55) \\
(56)(57)(58)(59)(60)(61) \\
(64)(66)(70)(72)(77)(84) \\
(85)(86)(87)(88)(89)(90) \\
(91)(92)\end{array}$ & 58 & 63 \\
\hline
\end{tabular}

According to IAIA's performance criteria a good-quality SEA process must be integrated, sustainability-led, focused, accountable, participative and iterative. Findings show that most of the outcomes are clearly related to this set of criteria, though interestingly the results presented in this thesis have suggested to consider: (i) the inclusion of a different performance criterion in four categories of principles; (ii) the recognition of another category of principle named 
herein as 'is innovative', which is one aspect of SEA that has been largely mentioned in recent literature. The reviewed list of performance criteria is presented in Table 4.

Table 4 - Inclusion of new performance criterion
1 Is integrated
- 1 Ensures an appropriate environmental assessment of all strategic decisions relevant for the achievement of sustainable development.
- 2 Addresses the interrelationships of biophysical, social and economic aspects.
- 3 Is tiered to policies in relevant sectors and (transboundary) regions and, where appropriate, to project EIA and decision making.
-4 SEA helps to manage risk and minimize conflict when individual projects are proposed.

2 Is sustainability- - 5 Facilitates identification of development options and alternative proposals that are led more sustainable.

3 Is focused

- 6 Provides sufficient, reliable and usable information for development planning and decision making.

- 7 Concentrates on key issues of sustainable development.

- 8 Is customized to the characteristics of the decision making process.

- 9 Is cost- and time-effective.

-10 SEA includes both the positive and negative impacts on human health.

4 Is accountable $\quad 11$ Is the responsibility of the leading agencies for the strategic decision to be taken.

- 12 Is carried out with professionalism, rigor, fairness, impartiality and balance.

- 13 Is subject to independent checks and verification.

- 14 Documents and justifies how sustainability issues were taken into account in decision making.

5 Is participative $\quad 15$ Informs and involves interested and affected public and government bodies throughout the decision making process.

- 16 Explicitly addresses their inputs and concerns in documentation and decision making.

- 17 Has clear, easily-understood information requirements and ensures sufficient access to all relevant information.

- 18 SEA ensures the inclusion of marginalized populations.

6 Is iterative

- 19 Ensures availability of the assessment results early enough to influence the decision making process and inspire future planning.

- 20 Provides sufficient information on the actual impacts of implementing a strategic decision, to judge whether this decision should be amended and to provide a basis for future decisions

-21 SEA enables system improvements and contributes to capacity building due to (mutual) learning between consultants, public authorities and the general public 
7 Drives innovation - 22 SEA identifies or stimulates new research directions or needs (e.g. policy or program gaps).

- 23 SEA stimulates the adoption of sustainability innovative strategies and approaches throughout the planning and decision-making process

(1) Category "Is integrated".- New performance criterion: SEA helps manage risk and minimize conflict when individual projects are proposed.

Several outcomes are related to this group of criteria. Of particular concern was the lack of explicit consideration of the SEA role in helping to manage risk and to minimize conflict of upcoming projects (NOBLE et al., 2013; SIMS, 2012). It is to be noted that SEA plays an important role in providing a better understanding of the acceptability of the project would be deemed acceptable, therefore giving greater certainty to decision-makers (NOBLE et al., 2013). This outcome is related to tiers of decision-making. Literature reports the role of SEA in improving decisions occurring in others tiers (COLE; BRODERICK, 2007; NOOTEBOOM, 2000). Regarding project level, for example, SEA allows identification of environmental issues which should be given special consideration by the EIAs at the project level (COLE; BRODERICK, 2007). Under a SEA umbrella, there is a focus on issues of concern which allows project EIAs to play a meaningful role. Therefore, it is postulated that the SEA role in helping to manage risk and to minimize conflict of upcoming projects represents a relevant criterion for SEA performance and effectiveness.

(2) Category "Is sustainability-led"

- No new performance criterion.

(3) Category "Is focused"

- New performance criterion: SEA includes both the positive and negative impacts on human health. 
There is an outcome which could improve this category. Health-related environmental issues deserve more attention as they are not directly related to the physical environment. In several countries SEAs are a legally requirement whereas Health Impact Assessments (HIA) are not. Health issues included in SEAs may reduce the need for distinct HIAs (DOUGLAS; CARVER; KATIKIREDDI, 2011). Integrating health issues into SEA represents a multisectoral approach which contributes to the protection and improvement of people's health (FISCHER; MATUZZI; NOWACKI, 2010), and increase the transparency of decision-making (BREEZE; LOCK, 2001). Further, SEAs can influence upstream determinants of health (DOUGLAS; CARVER; KATIKIREDDI, 2011; WRIGHT; PARRY; SCULLY, 2005). It is to be noted that SEA is based upon the precautionary principle, therefore can provide more comprehensive and healthier planning solutions (KØRNØV, 2009)

International guidance advocates consideration of health within SEAs. For example, the United Nations Economic Commission for Europe protocol on SEA considers human health as an integral part of SEA (UNECE, 2003). The European Union Directive (2001/42/EC) refers to environmental issues to be taken into account in SEAs, one of which is human health (CEC, 2001). However, health issues still need support in order to ensure the quality and consistency of SEA. It is, therefore, suggested the inclusion of a specific criterion related to health issue.

(4) Category "Is accountable"

- No new performance criterion.

(5) Category "Is participative"

- New performance criterion: SEA ensures the inclusion of marginalized populations.

IAIA criteria refer to the affected public. However, there is a need of explicit attention to the inclusion of marginalized populations. Engaging this segment of the public is challenging, particularly at highest levels of decision-making. This may explain why public participation is often weak in SEAs and fails to meaningfully engage key marginalized populations (HIPONDOKA; DALAL-CLAYTON; GILS, 2016), particularly in developing countries. 
Therefore, a key recommendation for performance criteria is to include a criterion which specifically refers to the inclusion of marginalized populations.

It is worth noting that public involvement should be proactive and stated explicitly as a planning goal. The inclusion of marginalized populations should start early and continue through the planning and assessment (NOBLE, 2004). Therefore, SEA allows this population to provide a well-informed input in meetings and empower them in influencing decision-making (HIPONDOKA; DALAL-CLAYTON; GILS，2016; WALKER; SINCLAIR; SPALING, 2013). Furthermore, involving marginalized segments of the public can increase communal awareness of environmental and sustainability issues (JOÃO; MCLAUCHLAN, 2014, SIMS, 2012) and eases the integration of affected values and interests (NOBLE, 2004).

Promoting the decision-making democratization is a cornerstone of sustainable development and a key aspect of the SEA process. The public is given an opportunity to comment on a proposal and its environmental impact before a decision is taken on how to proceed (HAMBLIN, 1999). This feedback mechanism ensures that marginalized populations are not left in the dark and with false hopes or unwarranted anxieties (WALKER; SINCLAIR; SPALING, 2013).

(6) Category "Is iterative"

- New performance criterion: SEA enables system improvements and contributes to capacity building due to (mutual) learning between consultants, public authorities and the general public

Outcomes of this group involve several issues such as acceptance of SEA validity and credibility (BUUREN; NOOTEBOOM, 2010; POLIDO; JOÃO; RAMOS, 2016; KØRNØV; THISSEN, 2000) and incorporation of sustainability issues into the PPP development or PPP approval/decision-making process (COLE; BRODERICK, 2007; ESTEVES; SOUZA, 2014; WALKER; SINCLAIR; SPALING, 2013).

However much consideration must be given to learning outcomes due to lack of their explicit link with IAIA integrated criteria. Learning refers to the experience in the workplace (or related training environments). It affects how someone (or an institution) handle with new knowledge generated through the assessment process, and it enables an appropriate EA of strategic 
decisions. Learning is a key goal of IA and therefore a relevant measure of effectiveness (JHATHAKUR et al., 2009). This reasoning is based on the fact that a good EA process has benefits outside the assessment process (in the future), as learning should change the values and actions of stakeholders in relation to their opinion about the environment. Outcomes related to individual and system learning contribute to PPP changes and capacity building (JHATHAKUR et al., 2009).

According to SEA literature on outcomes, SEA enables behavioural and attitudinal changes towards environmental issues of institutions and persons (including the public) and involved in the planning process (FISCHER et al., 2009; JHA-THAKUR et al., 2009; SLUNGE; LOAYZA, 2012; TETLOW; HANUSCH, 2012). Learning play a valuable longer-term role in changing individual and institutional norms and practices in support of sustainable development (KØRNØV; THISSEN, 2000). For example, spatial plan SEA in the Brunswick region (Germany) shows a scope for learning through SEA due to the participation, integration and monitoring functions of the tool (FISCHER et al., 2009). In this region, SEA had led to singleloop learning which enables modification of the plan. Amongst others, the assessment caused the rejection of some project proposals such as road bypasses (FISCHER et al., 2009). In UK, single-loop learning also occurred and led to better collection and care of baseline environmental data (JHA-THAKUR et al., 2009). SEA also sets the basis for double-loop learning as the tool provides spaces and moments for interaction, thus contributing to the development of closer working relationships and mutual understanding (JHA-THAKUR et al., 2009).

Based on the importance of learning in SEA, the main suggestion is to include explicitly this issue in the IAIA performance criteria. Our understanding of what makes SEA performant has advanced since IAIA performance criteria came about. Our main attention should now be on producing more evidence for what makes SEA performant. In this context, learning is crucial as SEA can act as a tool for learning. Developing the necessary learning environment contributes to ensure that SEA does result in value added.

(7) New category "Drives innovative"

This is a new category which encompasses SEA outcomes reported by the literature that could not be explicitly related to other IAIA's principles. This group includes outcomes that highlight 
the role of SEA in encouraging the adoption of innovative strategies and approaches to sustainability throughout the planning and decision-making process.

(i) New performance criterion: SEA identifies or stimulates new research directions or needs (e.g. policy or program gaps).

Literature reports that "SEA identifies or stimulates new research directions or needs (e.g. policy or program gaps)" (ACHARIBASAM; NOBLE, 2014). One may consider this outcome outside the mandate of the agency responsible for the SEA (ACHARIBASAM; NOBLE, 2014). However, according to Therivel (2004), SEA play an important role in identifying environmental problems raising issues that should be investigated. Acharibasam and Noble (2014) have reported that "SEA identified data gaps in baseline knowledge and resulted in new information gathering". This outcome depends on interactions between assessment tiers and/or people involved, and the willingness to use lessons learned in the previous tier. Therefore, it depends on decision-makers disposition to be materialized.

(ii) New performance criterion: SEA stimulates the adoption of innovative strategies and approaches to sustainability throughout the planning and decision-making process.

There is significant potential for SEA to be an important source of innovation. This situation may happen when inputs from the stakeholders are considered and included in the design and implementation of SEA into the planning activities and decision-making process (STOEGLEHNER; BROWN; KØRNØV, 2009). It is important to note that innovation occurs when decision makers do not assume that SEA is essentially the same as the existing planning process, and when there is not significant gaps between needs and available resources. For SEA to be performant, there must be 'ownership' by the decision makers of these 'additional' strategies and approaches to sustainability. Ownership means that decision makers have to want, use, and then incorporate SEA inputs within their decisions. There needs to be consideration of where in the planning and decision-making process SEA inputs would fit. It is also important to understand where inputs overlap with existing planning components, and where they are difficulties and opportunities for their uptake (STOEGLEHNER; BROWN; KØRNØV, 2009). 
Synthesis of the results

This step aimed to elaborate a methodological approach based on SEA literature for a systematic identification of SEA outcomes on decision-making. Based on literature review, a total of 98 SEA outcomes have been identified. Due to the high number of outcomes, it seemed coherent to use the IAIA performance criteria instead of the long list of outcomes. Each outcome was then related to their corresponding IAIA performance criteria. Outcomes without corresponding performance criteria were included as a new criterion in a new category of principles. The final list of criteria includes a total of 6 new criteria, within which health-related environmental issues deserve special attention as they are not directly associated to physical environment. Integrating health issues into SEA represents a multisectoral approach which could provide more comprehensive and healthier planning solutions based upon the precautionary principle.

A new category was added due to the necessity to highlight the adoption of innovative strategies and approaches to sustainability. This is important as it reflects the ownership by the decision makers of additional strategies and approaches to sustainability.

The approach outlined is primarily an additional contribution and is not meant as a substitute for approach taken thus far. It puts SEA in a wider perspective by bringing forward a number of criteria which are relevant nowadays.

\subsection{Identification of individual and institutional actors involved in the SEA processes}

We identified a total of 68 SEAs applied in Brazil from 1997 to 2016 (Annex 1). Tables 5, 6, 7 and 8 present data concerning the main institutions in terms of the MDAs, proponents, sectors and consultancies during the selected period.

The energy sector represents $48 \%$ of the total number of SEAs prepared during this period, which reflects its relevance to the country's SEA system. Regarding funding agencies, interestingly, SEAs has been applied twice under private initiatives funding. These applications in a non-mandatory context should be encouraged as they may suggest the understanding and awareness of environmental/sustainability issues including the necessity of SEA.

Inter-American Development Bank and World Bank shares almost 37\% of the 68 SEAs prepared during the period, which illustrates their relevance to the country. MDAs are 
responsible for a considerable number of SEA in low and middle income countries (TSHIBANGU; MONTAÑO, 2015). Historically they have played a key role in the use of SEA (SÁNCHEZ, 2006), as this instrument aims to safeguard environmental concerns and contribute to environmental governance (RICHARDSON; CASHMORE, 2011; CASHMORE; AXELSSON, 2013; CASHMORE et al., 2014). It is important to highlight that MDAs have often been dedicated to reshape the institutional framework and governance through approaches that goes beyond the evaluation of impacts (RICHARDSON; CASHMORE, 2011)

Table 5 - Sectors and number of SEA cases in Brazil between 1997 and 2018

\begin{tabular}{|c|c|c|c|}
\hline \multirow{2}{*}{ Sector } & \multicolumn{2}{|c|}{ Scale } & \multirow{2}{*}{ Percentage $(\%)$} \\
\hline & Regional scale $^{\mathrm{a}}$ & National scale $^{b}$ & \\
\hline Energy & 28 & 3 & 46 \\
\hline Multisector & 12 & 1 & 19 \\
\hline Transport & 8 & 2 & 15 \\
\hline Tourism & 6 & 2 & 12 \\
\hline Land use & 3 & 1 & 6 \\
\hline Natural resources & 1 & - & 1 \\
\hline Sanitation & 1 & - & 1 \\
\hline Sub-total & 59 & 9 & \\
\hline Total & & & \\
\hline \multicolumn{4}{|c|}{${ }^{\mathrm{a}}$ Refers to an area covering one or more city or states, but not all } \\
\hline \multicolumn{4}{|c|}{${ }^{\mathrm{b}}$ Refers to an area covering the whole country } \\
\hline
\end{tabular}


Table 6 - SEA funding agencies for the period 1997-2018

\begin{tabular}{lcc}
\hline MDA & Number of SEAs & Percentage (\%) \\
\hline Private initiatives & 2 & 2,9 \\
World Bank* & 6 & 8,8 \\
$\begin{array}{l}\text { Inter-American } \\
\text { Development Bank* }\end{array}$ & 20 & 29,4 \\
$\begin{array}{l}\text { Federal or state } \\
\text { environmental agencies }\end{array}$ & 41 & 60,3 \\
\hline
\end{tabular}

* One SEA has been applied under both WB and IDB fundings.

Source: self-elaboration

Findings show that most of SEA proponents are public institutions including the Brazilian Energy Company, states government, Ministry of Planning and Ministry of tourism (Table 7). The effective involvement of proponents is crucial as it may ensure the incorporation of SEA suggestions into the final PPP (LEMOS; SOUZA, 2010). Although there is little integration of environmental concerns in the PPP as a result of the SEA (MARGATO; SÁNCHEZ, 2014), this tool may provide good experiences on participation in the assessment and PPP development process (TAO; TAN; HE, 2007). Based on our findings, it is noteworthy that SEA in Brazil involved several institutional actors, which resulted in an increased number of stakeholders involved in the development of strategic actions. This opportunity may allow proponents to offer public a real say. For public PPPs, for example, such interaction may generates mutual learning processes between proponents (public authorities) and the general public (REGA; BALDIZZONE, 2015; TETLOW; HANUSCH, 2012). 
Table 7 - Top 10 SEA proponents for the period 1997-2018

\begin{tabular}{lcc}
\hline Proponent & Number of SEAs & Percentage (\%) \\
\hline Brazilian Energy Company & 11 & 16,2 \\
Group of Companies & 4 & 7,4 \\
Government of the state of Minas Gerais & 4 & 5,9 \\
Eletrobras and Cepel & 4 & 5,9 \\
Government of the state of Sao Paulo & 4 & 5,9 \\
Government of the state of Ceará & 3 & 5,9 \\
Ministry of Tourism & 2 & 4,4 \\
Ministry of Planning & 2 & 2,9 \\
Ministry of Tourism and Government of the state of Rio de Janeiro & 2 & 2,9 \\
Government of the state of Bahia & 2,9 \\
\hline
\end{tabular}

Source: self-elaboration

Regarding SEA consultancies for the period 1997-2018 (Table 8), LIMA and Arcardis Logos consultancies responded by $22 \%$ of SEAs conducted during the period. Consultancies play a key role in the practice of SEA as they coordinate the assessment process. Particularly in countries where SEA is non-mandatory with limitations in procedures and legislation, consultancies with experience may took advantage of SEA capability of functioning as a process facilitator, contributing to promote impartiality and a better management of conflicts (LEMOS; SOUZA, 2010). However, developing countries such as Brazil face important challenges such as resource constraints and economic and political pressures. In such situation, consultants are challenged to enable changes in attitudes towards environmental issues (THÉRIVEL; MINAS, 2002; SLUNGE; LOAYZA, 2012). 
Table 8 - Top 10 SEA consultancies for the period 1997-2018

\begin{tabular}{lcc}
\hline Consultancy & Number of SEAs & Percentage (\%) \\
\hline LIMA & 9 & 13,2 \\
Arcadis Logos & 6 & 8,8 \\
Soluções em Meio Ambiente & 3 & 4,4 \\
Deméter Engenharia & 3 & 4,4 \\
Prime Engenharia & 2 & 2,9 \\
Núcleo de Coordenação e Gerência & 2 & 2,9 \\
Hydros Engenharia & 2 & 2,9 \\
Independent consultants & 1 & 1,5 \\
Independent consultants and Instituto Cearense de Ciências Naturais & 1 & 1,5 \\
Scholars/academics & 1 & 1,5 \\
\hline
\end{tabular}

Source: self-elaboration

Table 9 indicates the number of individuals involved in SEA processes for the period 19972018. Interestingly, SEAs applied to the DER/IDB Road Recovery Program (Programa de Recuperação de Rodovias) and the Program for Improvement of the Urban Environmental Quality of the state of Amapá (Programa de Melhoria da Qualidade Ambiental Urbana do Amapá) were conducted by internal teams of the institutional proponent. Therefore, in this case, consultants were considered as proponents as well.

Findings summarised in Table 9 provide an overview of the number of stakeholders involved in SEAs within a non-mandatory context. Consultants and public were found to be the most numerous groups, while MDA representatives were the lowest. 
Public participation is considered of great value to SEA as it constitutes an effective way to increase the validity and legitimacy of environmental assessment process (BUUREN; NOOTEBOOM, 2010). In our case, public group numbered 413 individuals (45,58\%), thus reinforcing the (numeric) relevance of public participation in SEA processes in Brazil.

Table 9 - Number of SEA individual actors for the period 1997-2018

\begin{tabular}{|c|c|c|c|c|}
\hline & $\begin{array}{l}\text { Actors whose } \\
\text { contacts could be }\end{array}$ & $\begin{array}{l}\text { Actors whose } \\
\text { contacts could }\end{array}$ & \multicolumn{2}{|c|}{ Total } \\
\hline Proponents & 72 & 21 & 93 & $10,3 \%$ \\
\hline Consultants & 325 & 50 & 375 & $41,4 \%$ \\
\hline Consultants and proponents ${ }^{\mathrm{a}}$ & 2 & 2 & 4 & $0,4 \%$ \\
\hline Environmental agencies representatives & 11 & 1 & 12 & $1,3 \%$ \\
\hline MDA representatives ${ }^{b}$ & 5 & 0 & 5 & $0,6 \%$ \\
\hline Public & 327 & 86 & 413 & $45,6 \%$ \\
\hline Unkown ${ }^{\mathrm{c}}$ & 4 & 0 & 4 & $0,4 \%$ \\
\hline Total & 746 & 160 & 906 & $100 \%$ \\
\hline
\end{tabular}

Source: self-elaboration

Arguably, the qualitative aspects of public participation and, most of all, the contribution of the public to SEA effectiveness, cannot be measured merely in terms of the number of people involved in SEA processes. In fact, Lemos and Souza (2010) underline the lack of interest of the local population to participate in strategic decisions regarding touristic activities (in the municipality of Bueno Brandão, Minas Gerais State - Brazil), possibly due to the fact that local population did not feel part of tourism as they were not professionally involved in tourism related activities or did not feel affected by touristic activities in their daily lives.

In Kenya (a 'regulated context'), Walker, Sinclair and Spaling (2013) highlight the inadequate notice to participants, as individuals were informed few days prior to the meetings. In Burundi 
('non-regulated'), limited financial power was referred as a constraint to a sufficient involvement in the assessment process (WORLD BANK, 2011). These are challenges to overcome in order to ensure a greater ownership of the final PPP (HAMBLIN, 1999; NOBLE, 2009; SIMS, 2012).

In Brazil, the network of actors is characterized by a predominance of proponents and consultants who represent about $52 \%$ of the agents involved in the SEA process. It is to be noted that some actors have been involved in more than one SEA. Actors involved in SEAs are part of networks which are "common denominators in cases where different stakeholders have come together in order to effectively deal with problems and dilemmas related to natural resource" (SCHOLZ; WANG, 2006). It is, therefore, important to understand how actors can use their position to influence the decision-making process.

It is noteworthy that some actors have central positions in a network, and thus are able to exert influences over others, and have more access to valuable information which can put them at an advantage (BURT, 2004). Who occupies key positions, and how they employ their influential situation will therefore have an impact on governance outcomes. According to Bodin and Crona (2009) "if individuals in favourable positions in the network are unaware of the necessity to, or unwilling to engage in, collective action they may end up, deliberately or not, blocking initiatives by others."

In some situations, occupying a favourable position in a network may not necessarily lead to higher influence. For example, if an individual has formal authority, he/she can be influential without necessarily possessing an advantageous position. However, individuals that did not hold neither a key network position nor formal of authority ranked lower in terms of influence (BODIN; CRONA, 2008). Regarding SEA, it is important to guarantee that all stakeholders (including those with less influence) concerns are taken into account (THÉRIVEL; MINAS, 2002; BUUREN; NOOTEBOOM, 2010). SEA can play an important role in ensuring the inclusion of marginalized populations, those without key network position nor formal level of authority (WALKER; SINCLAIR, SPALING, 2013; HIPONDOKA; DALAL-CLAYTON; GILS, 2016). It important to make sure that the representatives of different, even marginalized, subgroups are being invited and engaged in participatory processes (NOBLE, 2009). Participant network analysis can thus be used in guiding decision-makers communication and engagement efforts in order to increase efficiency, and/or to focus on specific subgroups (see also MERTENS et al., 2005). 


\section{Synthesis}

This chapter aims to characterize Brazil's SEA practice through a mapping of actors and institutions in the assessment process. Based on the 68 SEA cases which are estimated to be the total number of SEA in Brazil, actors and institutions involved in the assessments were identified through report review and the application of applied a snowball method by asking actors to refer other acknowledged actors and institutions to be included.

Findings indicate a predominance of MDAs as agents that had requested an SEA, thus confirming their key role to the use of SEA in Brazil. Also, most of proponents of strategic actions are public institutions. SEA constitutes an opportunity for mutual learning and an occasion for public authorities to offer public a real say. Consultancies appear as key actors in the practice of SEA in the country due to their coordination role. However, they have to deal with limitations in procedures and legislation, as well as resource constraints and economic and political pressures.

Consultants and public were found to be the most numerous groups of actors, while representatives of MDAs were the lowest. Little is known about the adequate number of actors to be involved in SEA, however, it is important to involve all stakeholders (including public) and to promote their integration and active participation.

\subsection{Identification of SEA outcomes}

(i) Questionnaire background

Of 489 questionnaires sent, a total of 88 questionnaires were filled out, corresponding to a response rate of $18 \%$, which is a bit higher than the usual response rate for a self-administered mail survey (15 to 20\%, according to BHATTACHEJEE, 2012). Of the 88 questionnaires, 53 were totally filled out, 35 were partially filled out (of them, 3 respondents omitted questions of the questionnaire characterization section, 21 just filled out the first questionnaire section corresponding to the identification of SEA in which they were involved, and 11 participants filled out some questions of the first and second sections). This explains why the number of respondents varies from question to another. Apart from that, I have received 16 e-mails from participants explaining why they could not fill out the questionnaire. Eight judged their 
participation in the assessment limited. Two participants apologized as they were not able to fill out the questionnaire due to others activities. And six participants are no longer working with SEA.

Respondents that identified themselves include 38 consultants, 3 environmental agencies representatives, 2 proponents, 3 public representatives and 42 representatives which did not identify themselves. Results represent the collective experience of 88 individuals across 63 SEA initiatives. There were no significant differences between consultants, proponents and other participants involved as respondents were neutral on many questions.

A total of 13 SEAs (Approximately 19\%) were not identified by questionnaire survey participants as assessments in which they have been directly or indirectly involved (Table 10). Participants added 9 SEAs as assessments not included in the list provided (Table 11). Findings show that the first SEA in Brazil might be the "Planejamento estratégico do turismo ecológico / sustentável em âmbito federal. EMBRATUR" instead of the "Avaliação Ambiental Estratégica do Gasoduto Brasil Bolivia". Although the term "strategic planning" may not be appropriate to refer to SEA, it should be noted that the concept of SEA was not in mainstream environmental field at that time. This should not detract from the fact that some form of assessment were required for a strategic action. Such initiative can be attributed to an implicit recognition of the necessity of EA for a certain type of action. 
Table 10 - SEAs without participants involved in the questionnaire survey

2002 - Avaliação Ambiental Estratégica do Rio da Areia - Paraná

2002 - Avaliação Ambiental Estratégica do Plano Federal Plurianual - Esfera Federal

2002 - Avaliação Ambiental Estratégica do Plano Indicativo 2003-2012 - Esfera Federal

2003 - Avaliação Ambiental Estratégica do Portfólio dos Eixos Nacionais - Ministério do Planejamento - Esfera Federal

2004 - Consolidação urbana de Paulínia - Municipal

2005 - Avaliação Ambiental Estratégica do Programa de Acessibilidade a Municípios de Pequeno Porte com Baixo Índice de Desenvolvimento Humano - PROACESSO - Minas Gerais

2005 - Avaliação Ambiental Estratégica do Programa de Eletrificação Rural do Noroeste de Minas Gerais - Minas Gerais

2007 - Avaliação Ambiental Estratégica do Programa Brasília integrada GDF/BIDTransporte Distrito Federal

2009 - Avaliação Ambiental Estratégica da Bacia do Rio Turvo - Bacia do Rio Turvo

2009 - Avaliação Ambiental Integrada da Bacia do Rio Iratim - Paraná

2010 - Avaliação Ambiental Estratégica do Programa de Desenvolvimento Urbano Regional do Ceará - Vale do Acaraú - Ceará

2011 - Avaliação Ambiental Estratégica do Corredor Bioceânico Ferroviário - Eixo de Capricórnio- Esfera Federal

2014 - Avaliação Ambiental Estratégica do PRODETUR Nacional no Estado do Mato Grosso do Sul - Polo Campo Grande e Região 
Table 11 - SEAs identified by participants (in portuguese)

11990 - Strategic planning of federal eco-sustainable tourism. EMBRATUR [Planejamento estratégico do turismo ecológico / sustentável em âmbito federal. EMBRATUR]

22007 - Integrated Environmental Assessment of the Parnaíba Basin - Parnaíba Basin - Northeast (Piauí and Maranhão) [Avaliação Ambiental Integrada da Bacia do Parnaíba - Bacia do Parnaíba - Nordeste (Piauí e Maranhão)]

Available at:

http://www.epe.gov.br/MeioAmbiente/Paginas/AAI/MeioAmbiente 3.aspx?CategoriaID=101

3 2006-2008 - Evaluation of the aquatic ecoregion of the Iguaçu River, PR [Avaliação da ecorregião aquática do rio Iguaçu, $P R]$

42008 - Strategic Environmental Assessment for the Tocantins-Araguaia Basin Strategic Water Resources Plan [Avaliação Ambiental Estratégica para o plano estratégico de recursos hídricos da bacia do Tocantins-Araguaia]

52017 - Strategic Environmental Assessment of Ceará's Environmental Sanitation Policy [Avaliação Ambiental Estratégica da Política de Saneamento Ambiental do Ceará]

Available at:

http://www.institutoagropolos.org.br/img/uploads/arquivos/jhjkjk_201120171768515778.pdf

6 Strategic Environmental Assessment of the naval pole in the Bay of todos os santos [Avaliação Ambiental Estratégica do polo naval na Baia de todos os santos]

7 Santo Antonio River Environmental Assessment, MG [Avaliação Ambiental do Rio Santo Antônio. $M G]$

8 Strategic Environmental Assessment of the Agriculture of the state of Minas Gerais [Avaliação Ambiental Estratégica da Agricultura do estado de Minas Gerais]

9 Porto Central - Municipality of Presidente Kennedy - ES [Porto Central - Município de Presidente Kennedy-ES]

Table 12 - Number of questionnaire respondents per SEA (follows)

\begin{tabular}{lll}
\hline SEA & $\begin{array}{l}\text { Number of } \\
\text { respondents }\end{array}$ & Percentage \\
\hline
\end{tabular}

\begin{tabular}{lll}
\hline $\begin{array}{l}2,5,15,12,14,16,19,21, \\
41,58,59 \text { and } 66\end{array}$ & 1 & $1,1 \%$ \\
$3,24,27,36,43,52,53$ & 2 & $2,3 \%$ \\
$8,11,15,20,22,60,62,63$, & 3 & $3,4 \%$ \\
$\begin{array}{l}\text { and } 64 \\
23,28,33,35,37,45,46,\end{array}$ & & \\
67, and 50 & 4 & $4,6 \%$
\end{tabular}




\begin{tabular}{lcc}
\hline SEA & $\begin{array}{c}\text { Number of } \\
\text { respondents }\end{array}$ & Percentage \\
\hline 1,29 and56 & 5 & $5,7 \%$ \\
$25,31,38,47,48$ and 54 & 6 & $6,8 \%$ \\
$10,30,34,42,55$ and 65 & 7 & $7,9 \%$ \\
39 and 44 & 8 & $9,1 \%$ \\
32 and 57 & 9 & $10,2 \%$ \\
\hline
\end{tabular}

(ii) Interview

The first question asked to interviewees was related to how they were involved in the SEA process. This question is meant to understand how people are involved in such assessment in a non-mandatory context. Some interviewees reported that they were already working with environmental studies and they were invited to join the SEA consultancy team. Some participants were already working in the consultancy in the charge of the SEA. Therefore they have familiarity with the underlying science basis for environmental studies. One interviewee was working in the public sector responsible for the plan. In this way, (s)he get involved in the SEA. Another interviewee was invited to join the SEA consultancy team because of his Master Degree Thesis which focus on the area covered by SEA. One interviewee was invited by the MDA in the first SEA conducted in the country because (s)he was among the scarce specialists with professional expertise to conduct EAs at that time.

The second question was related to elements that motivated the application of SEA in a nonmandatory context. Three interviewees attributed the use of SEA to key actors who knew the instrument and its important contribution to strategic decisions. Of particular concern was SEA \#23 which was requested by the Secretary of Environment of Minas Gerais State. He knew benefits attached to this tool and played an important role in the application of this instrument. He highlighted that SEA does not aim at facilitating the EIA environmental license process. However, the tool can indeed facilitate a process of collaborative decision-making, if users implement it in accordance with the best practice principles. 
Another interviewee mentions that governments and NGOs expressed concern that EIA was not effective. Therefore, there was a need of a more adapted tool with the benefits of an additional layer of assessment to the planning structure. One participant highlights that many of the countries that have experimented with SEA at the national level have begun to extend its use due to bilateral development cooperation. The case of Brazil is not different as the World Bank financed its first SEA (Annex 1). However, recently, some institutions required SEA. For instance, SEA \#27 were required by the Federal Audit Court (Tribunal de Contas da União) through its technical opinion of 2012. According to the interviewee, some years ago, this institution was thinking about constituting a group of environmental and social impact specialists as several strategic actions were cancelled due to their associated environmental and social risks. The Brazilian Government Agency for Law Enforcement and Prosecution of Crimes (Ministério Público) have also played an instrumental role in introducing SEA in the country.

According to a participant (a former proponent and consultant), there are contextual factors influencing the application of SEA. For example, the energetic sector is among the rare sector that implemented a strategic planning system, in such situation the use of SEA (Integrated Environmental Assessment) improves decision-making by introducing environmental concern in planning processes. Further, there are territorial conflicts in some regions. For instance, in the Madeira river region, there are production of gold and hydro energy. Moreover, the river serves as water street to evacuate soya locally produced. In this particular situation, SEA plays an important role in organizing priorities, by showing strategic reasons for change.

From the third question onward, interviewees were invited to describe context factors that promote the occurrence of SEA outcomes in the country. Sometimes questions were specific based on the questionnaire previously applied.

(iii) Questionnaire and interviews results and discussion

Figures 2 to 8 summarise the results from our verification of the occurrence of SEA outcomes in Brazil. Each figure provides for a more detailed picture, showing what questions obtained higher and what sections obtained lower scores. Regarding questions of group A, most participants strongly or partially agreed that SEA addressed the interrelationships of biophysical, social and economic aspects (A2) (77\%), and was tiered to policies in relevant 
sectors and (transboundary) regions and, where appropriate, to project EIA and decision making (A3) $(57 \%)$.

Several participants commented that SEA allowed and improved the implementation of projects. For example, in the questionnaire, a consultant highlights the role of SEA in the implementation of several projects in 68 cities of Ceara state. SEA improved biodiversity conservation and sustainability of the Caatinga biome (SEA \#43). Regarding SEAs \#52 and \#53, interviewee \#6 (consultant) commented that SEA findings were incorporated in lower level of decision making as other alternatives were considered in order to minimize strategic impacts.

Some hydroelectric projects in the southern Paraiba basin were reformulated to reduce negative impacts thanks to the SEA (SEA \#31). Some comments raised, however, concern disagreed responses. Participants mostly, refer to political willingness to commit to SEA and to its recommendations. Actor 4 (consultant) mentions that several SEAs were conducted at a late stage in the strategic action design cycle, when many projects have been implemented (SEA $\# 39, \# 45$ and \#65). This may be viewed as a lack of knowledge and understanding of what SEA is and may beqq attributed to the lack of legislation on SEA in Brazil. Interviewee \#1 (environmental agency) mention that PPPs stakeholders had little knowledge of the SEA (SEA \#25). Interviewee \#3 (consultant) attributes the application of SEA to the requirements of InterAmerican Development Bank which requires the SEA to be performed during the Credit Line preparation process. Actually, SEA findings were not taken into account in the decision making (SEA\#11).

Figure 3 - Questions of group A "is integrated"

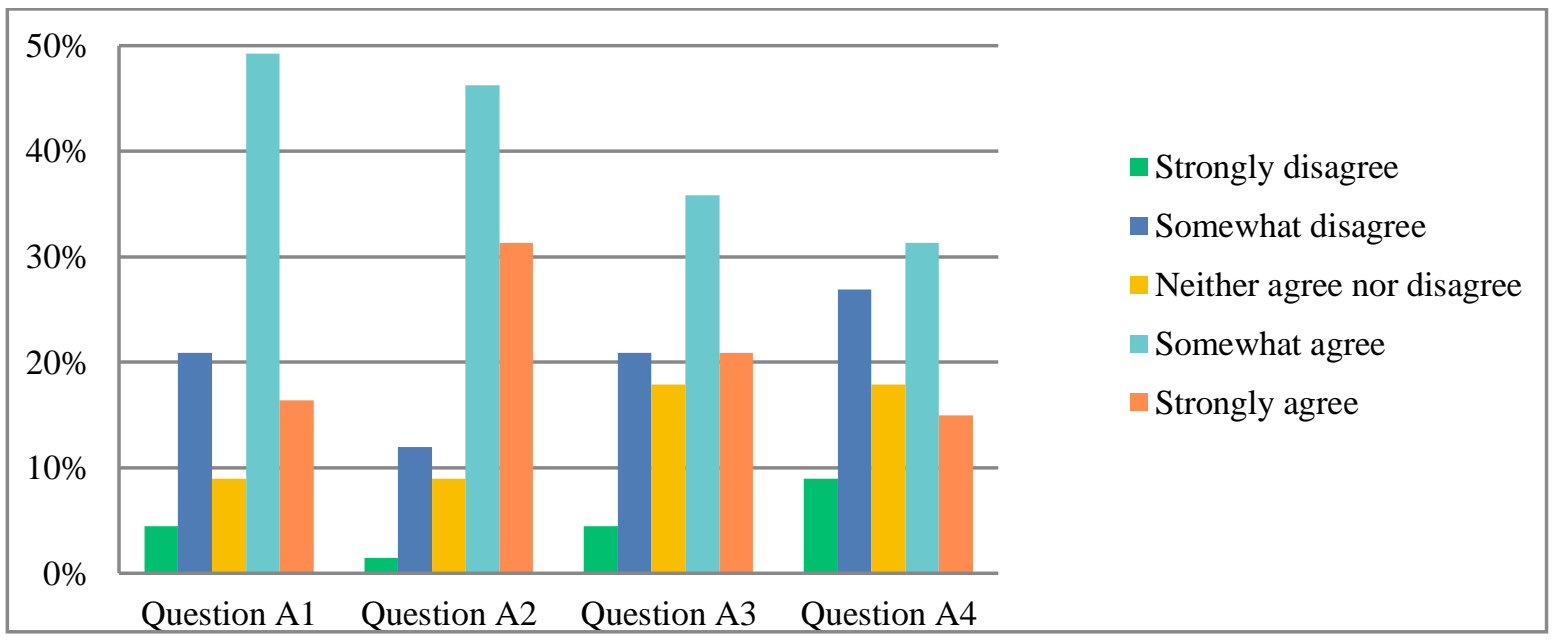

Source: self-elaboration 
SEA process has the potential to improve the efficiency of tiered decisions. It may act as a reconciliatory tool of different administrative levels, systematic tiers and sectors (FISCHER, 2007). A tiered approach to SEA can enable transparency, integration and effective streamlining of strategic planning. Furthermore, connections with other strategic actions may contribute to avoid duplication (FISCHER, 2007). However, the capacity and political will for explicit planning and policy-making is weak in several countries (BINA, 2007), including Brazil. Therefore, SEA has to address this challenge.

Figure 4 - Question of group B "is sustainability-led"

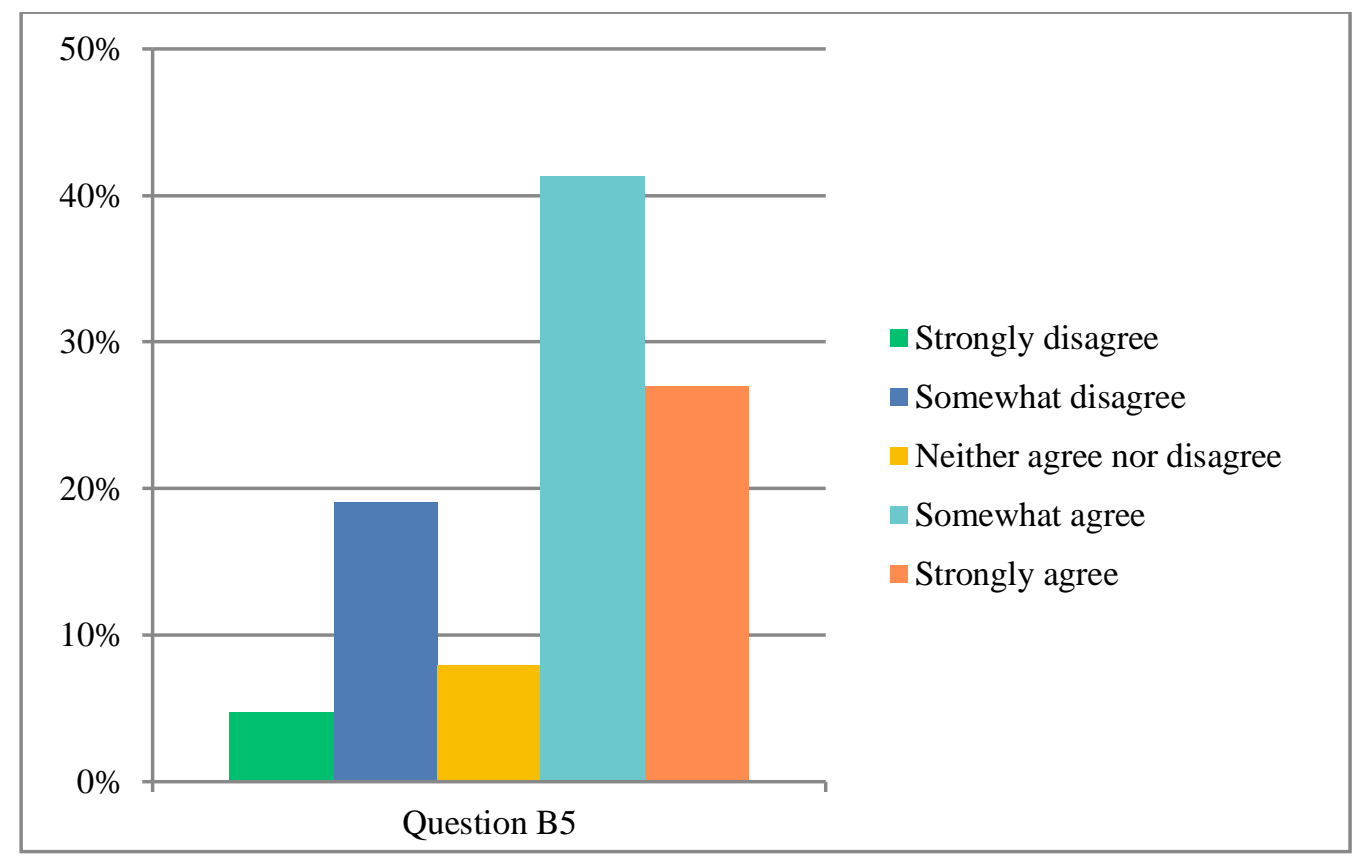

Source: self-elaboration

Regarding question B5, approximately $27 \%$ of participants strongly agreed, $41 \%$ partially agreed, $8 \%$ neither agreed nor disagreed, $19 \%$ partially disagreed and 5\% strongly disagreed. Despite the high percentage of agreement, there are some subtle differences between supporting comments. For example, a respondent of questionnaire place more emphasis on sustainable alternatives identified based on scenarios of medium and long term in the energetic sector. Another participant referred to sustainable successful projects identified based on participatory workshops (SEA \#43). On the other hand, interviewees \#1 (environmental agency) and 2 
(consultant) reported omissions and deficiencies observed in the development of alternatives. Regarding SEA \#11 (interviewee \#2 - consultant), alternatives involved three options of channel rectification resulting in segmentation of the project in order to facilitate the environmental license approval. SEA \#25 (interviewee \#1 - environmental agency) alternatives were not adequately considered as the environmental license process of electrical energy is strongly influenced by economic aspects such as implementation costs and firm energy generated.

SEA literature refers to appropriate development of alternatives as a challenge in both highincome and low and mid-income countries such as Denmark (BIDSTRUP; HANSEN, 2014), Finland (SÖDERMAN; KALLIO, 2009), Vietnam (SLUNGE; TRAN, 2014) and Brazil (MALVESTIO; MONTAÑO, 2013). Efforts have been made to overcome weaknesses related to alternatives. For example, recommendations and guidance to improve the practice are available across the EU (GONZÁLEZ et al. 2015). SEA poor compliance with alternatives might partly or indirectly be attributed to inadequate legal arrangements. As a first step, it seems that SEA should be built on a solid and context-adapted legal arrangement as this may contribute to avoid inadequacies (TSHIBANGU, 2018).

To make environmental studies more useful, a participant suggests to separate companies that are in charge of the engineering works from those that are in charge of the environmental studies. Since the same company is responsible for the strategic action and SEA, the strength of the engineering departments is prevalent, and alternatives are not considered especially when there is a very important issue (SEA\#47 and SEA\#48). It is important to note that Brazil does not have a technical institution in charge of SEA. In such situation, there is an urgent need to overcome institutional and technical constraints in order to take profit of SEA outcomes. 
Figure 5 - Questions of group C "is focused"

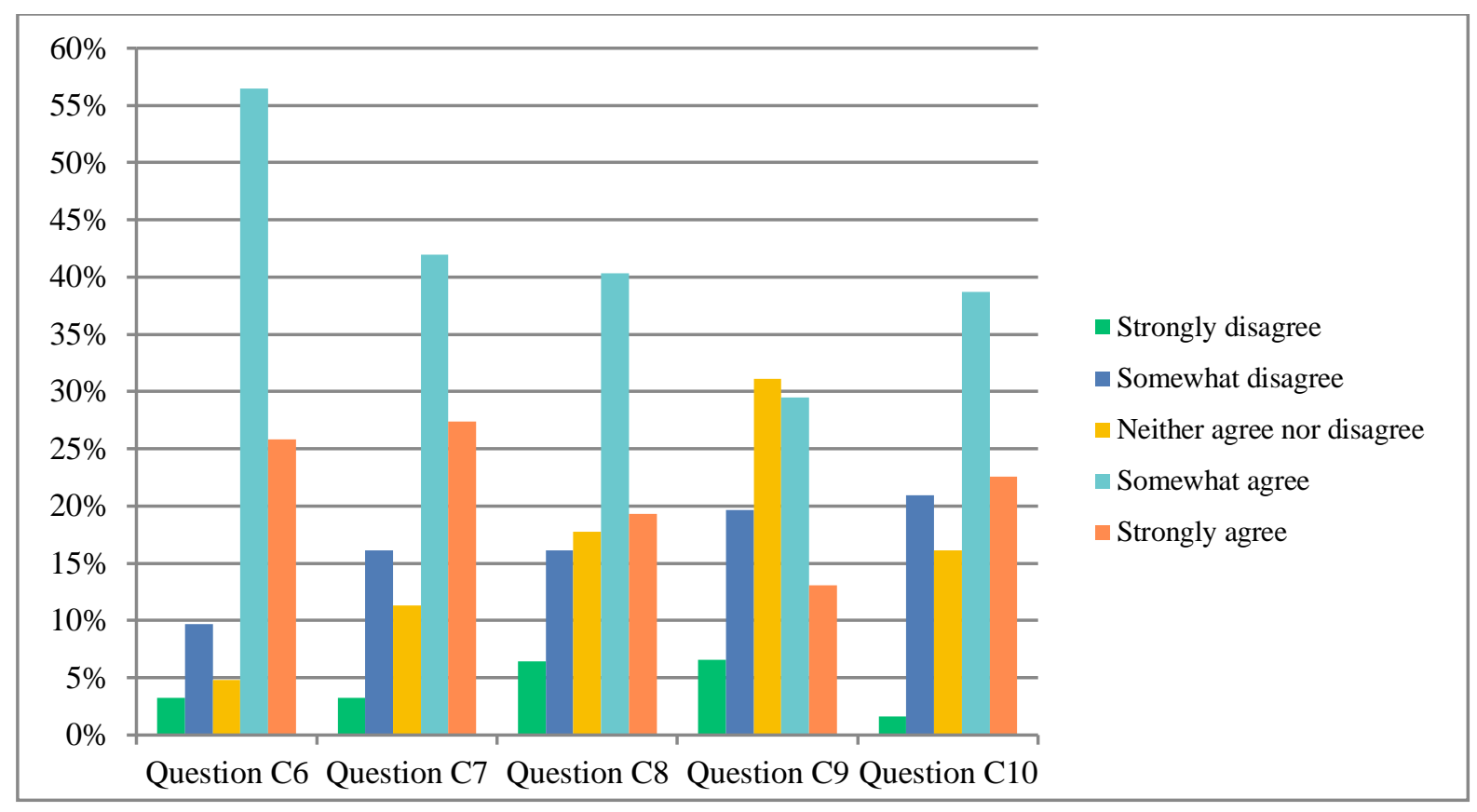

Source: self-elaboration

As shown in Figure 5, there were more than 50\% of agreed answers for most of the group C questions. However, question 9 deserves special attention as most of respondents considered that SEAs were not cost- and time-effective. According to interviewee \#1 (environmental agency), time for information gathering (mainly primary data) and, vulnerabilities and impact assessment (which involved hundreds of hydroelectric plants localized throughout the large hydrographic basins of Minas Gerais State) was very short, only 5 months. Actor 9 which was neutral in its response to question 9 argues that SEA processes (SEA\#42, SEA\#56) took too much time. According to an interviewee, the cost of each SEA \#23 was 1 million Real at that time. These assessments were completed in approximately one year. One consultant participant reported that there is a need to focus more attention on this issue as studies are lacking to corroborate cost and time effectiveness of SEA.

There is little, if any, published information on cost and time effectiveness of SEA. But international experience suggests that there is a need for SEA to be brief and efficient. According to Therivel (2004), for a reasonable SEA, 50 to 100 person-days are enough. The duration can increase the cost of the whole process (KONTIĆ; DERMOL, 2015) and appears as a reason for development restriction (SONG; GLASSON, 2010). This leads to the suggestion that SEA should be cost-effective, appropriate, reasonable and commensurate with the scope of 
the strategic action. As Therivel (2004) states: "Resources needed depend on the type of PPP and how efficiently the SEA is carried out. (...) if SEA is done badly, all of the costs can be incurred with no benefits at all in terms of an improved strategic action.”

Figure 6 - Questions of group D "is accountable"

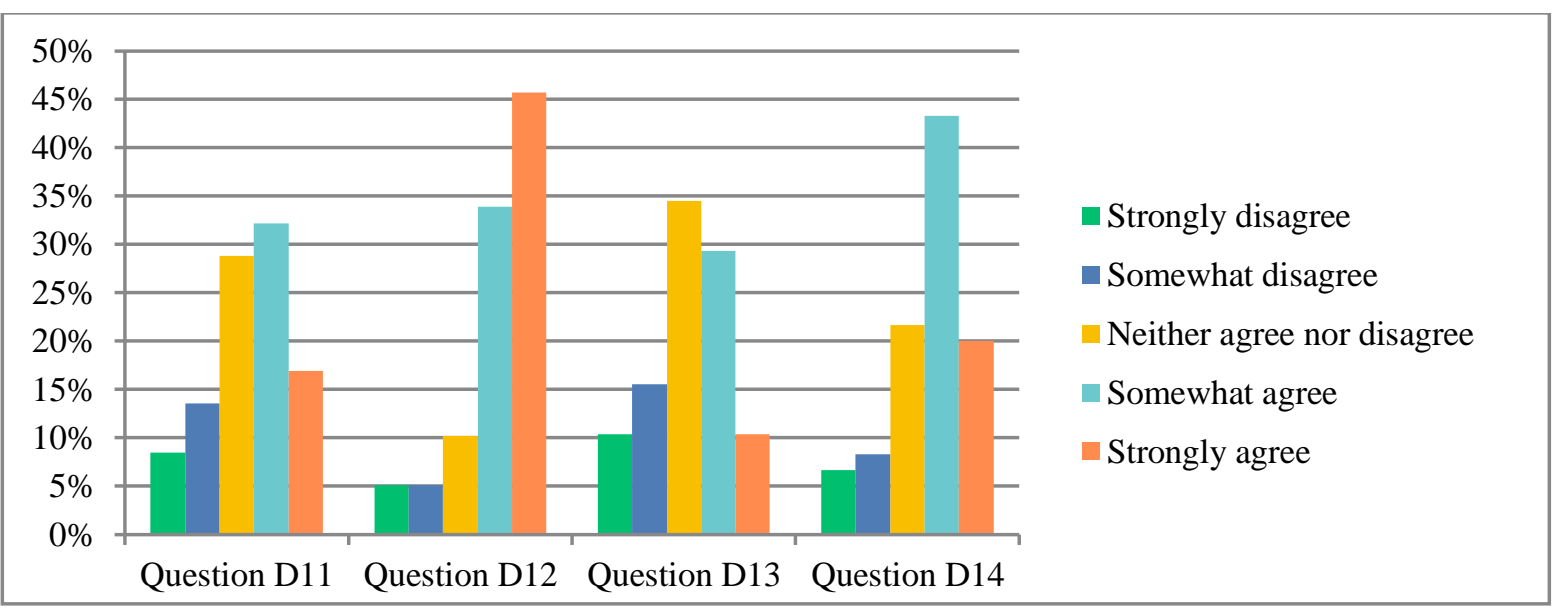

Source: self-elaboration

Regarding group D, participants agreed to most of questions. An important insight arising out of the comments pertained the way SEA was carry out (Question D12). Interviewee \#3 (consultant) reports that SEA \#11 was carried out with professionalism and rigor, which led to pressures and clashes with government representatives on what could be placed in the assessment report. Interviewee \#6 (consultant) states that difficulties in Brazil are often more acute by virtue of political pressures facing the country. It is important to note that the way SEA is carried out in Brazil depends partly on the consultancy. Malvestio (2013) suggests that distinct approaches to SEA are beginning to emerge in the country, based on the capacity building course undertook by the practitioners. There is no strong central model of the SEA process to provide the fixed reference point for practitioners, so the nature of professional training at tertiary institutions and subsequent professional updating programmes may be leading to divergence in perception of what constitutes adequate SEA.

There is little published information on morality values in conducting SEA. But international experience suggests that it is important for impact assessment practitioners to be aware of ethical principles (HIPONDOKA et al., 2016; VANCLAY et al., 2013). 
Question D13 also deserves special attention as a significant number of participants agreed with this statement. Further, comments provide interesting rational motive for theirs answers. Amongst those that agreed with question D13, interviewee \#7 (consultant) refers to the dissemination seminars and the availability of studies online as a way to allow independent verification and control (SEA\#55, SEA\#57). Interviewee \#6 (consultant) states that the civil society participated of the whole process acting as controller.

Recurrently workshops were organized to keep public updated. According to the interviewee, these constitute a form of "accountability" of what was being done and served to be aware of public needs (SEA\#43). Interviewee \#1 (environmental agency) highlights that SEA \#23 and \#25 were conducted by a consultancy and critically reviewed by the COPPE - The Alberto Luiz Coimbra Institute for Graduate Studies and Research in Engineering. This process guaranteed impartiality, balance, independent checks and verification of the assessment. The interviewee could observe that some parts of the SEAs \#23 and \#25 were done twice as the COPPE did not agree with the first version of the text, particularly due to the fact that the consultancy were considering SEA as a big EIA. Further, COPPE also made sure that requirements of the term of reference was considered.

On the other hand, several respondents disagreed with question D13. Regarding SEA \#32, interviewee \#9 (proponent) comments that checks and verification were ideological, which turned the process extremely exhausting. interviewee \#4 (consultant) and 8 (proponent) refer to the role of the Brazilian Government Agency for Law Enforcement and Prosecution of Crimes (Ministério Público), and suggest that this should be better defined in the process. Therefore, there is a need of a legal framework to state the role of each stakeholder. According to interviewee \#5 (consultant), the lack of regulation does not allow systematic checks and verification of SEA. It should be remembered that SEA accountability is not a matter of one or two governmental entities, but rather requires the creation of validation mechanisms involving SEA actors.

Regarding question D14, interviewee \#4 (consultant) and 5 (consultant) attributed the lack of documentation and justification of how sustainability issues were taken into account in decision making to the absence of a well-defined planning system, especially regarding long term activities. Participants could observe that the lack of data induce a superficial analysis of sustainability issues and the lack of development and implementation of sustainability goals. This is an important weakness to overcome. 
Figure 7 - Questions of group E "is participative"

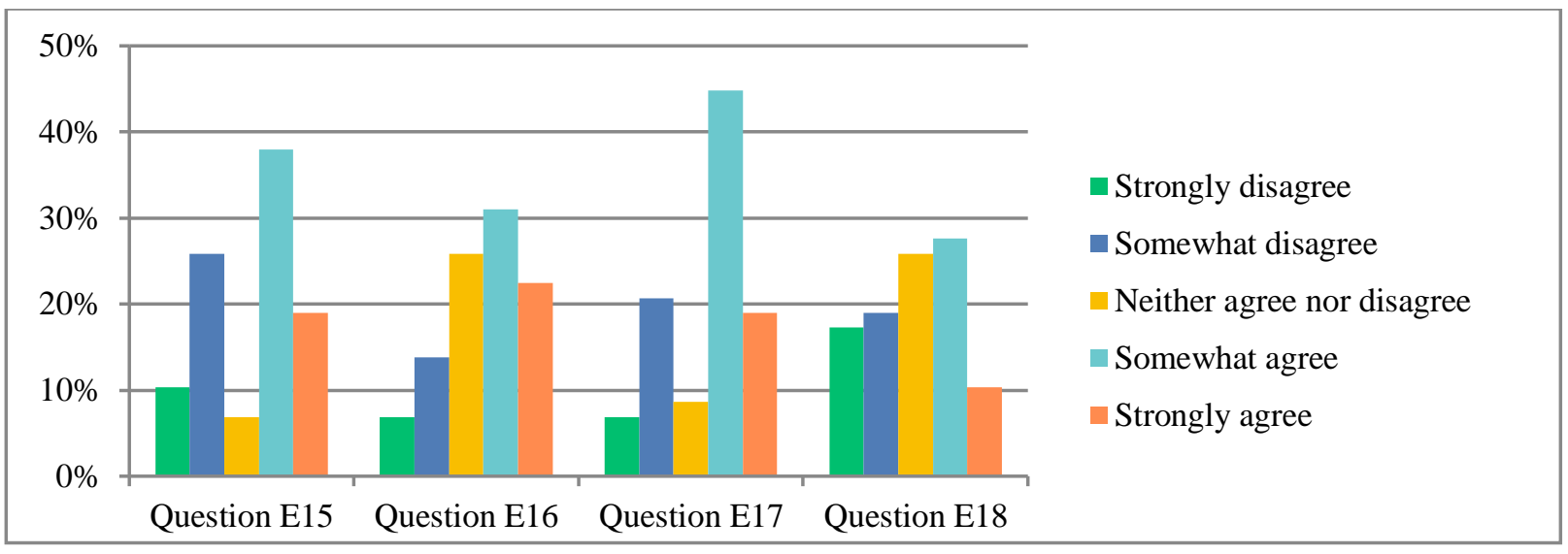

Source: self-elaboration

Questions E15, E16 and E17 obtained a high return of agreed or strongly agreed replies (Figure 7). Meanwhile, 37,93\% respondents agree with question E18, 36,21\% disagree and 25,86\% were neutral in their response. Comments provide interesting complementary information. Regarding question E15, interviewee \#6 (consultant) of SEA\#43 who took part of the whole process commented that there was an intense participation of civil society. Decisions makers were concern about increasing the number of social actors. Another participant of the same SEA reported that workshops were organized and involved, among others, representatives of municipal governments, NGOs, universities teachers and rural producers.

Other comments show different views. According to interviewee \#9 (proponent - SEA\#42 and \#56), public hearings are very insipid due to the lack of transparency and accountability. There is a need to discuss how to adequately involve communities, especially those directly impacted. Another respondent $\left(\mathrm{NI}^{1}\right)$ referred to the challenge of public participation which lies in the interests of different stakeholders. SEAs \#23 and \#25 were participative according to interviewee \#1 (environmental agency) as they involved a comprehensive public participation and consultation process. For these SEAs, considerable effort was undertaken to involve the public even though during the course of the consultation period, few responses were received. In the SEA \#11 (interviewee \#3 - consultant), the government played a questionable role as its representatives did not allow the SEA team to engage with communities or take part in the public hearing. Rather, another team was hired to conduct this task. It seems that public hearing aimed to present the strategic action. Interviewee \#9 (proponent) with the same point of view

\footnotetext{
${ }^{1}$ The participant responded to the questionnaire without providing $\mathrm{SEA}(\mathrm{s})$ in which he was involved
} 
commented on question E16 that public participation is not taken seriously (SEA\#47 and SEA \#48). It is rare for some change to occur because of public inputs. Another participant could notice that the access and readability of reports were limited. Many people struggle with illiteracy and language barriers. Further in one SEA, the report was disseminated via a website and subsequently removed as the proponent did not agree of the assessment results.

Concerning the inclusion of marginalized populations (Question E18), most of comments report that the involvement of most vulnerable is usually neglected. On SEA \#19, a respondent of questionnaire comments that certainly the report referred to marginalized populations. However, this does not mean that their views were taken into account by decision makers.

Stakeholders' consultation within the SEA provides a transparent assessment throughout the planning process and improves the PPP with comments collected (BUUREN; NOOTEBOOM, 2010; SANCHEZ; SILVA-SÁNCHEZ, 2008). Further, SEA alerts about the effects and consequences of a strategic action (NOBLE et al., 2013; REGA; BALDIZZONE, 2015). Ideally, SEA has to consider public concerns. However, such ideal is challenging to implement in developing countries particularly those which score below international average in terms of accountability and transparency of governmental decisions (DUSIK; XIE, 2009). Further, there is a need to ensure tangible input from public review and public hearing (WALKER et al., 2014; HIPONDOKA et al., 2016). For example, in Namibia, participants in public meetings sought if the strategic action would generate job opportunities (HIPONDOKA et al., 2016).

On question E18, interviewee \#5 (consultant) comments that there were traffickers in public hearings. They worried about how their "business" would be affected. Rega and Baldizzone (2015) attributed this limited input to insufficient knowledge of the SEA. Therefore, while it is necessary to explicitly consider public inputs, it is also important to educate communities about proposed strategic action before a major decision affecting them is taken (HIPONDOKA et al., 2016). According to interviewees \#4 (consultant) and \#8 (proponent), the need of educating stakeholders is crucial as he could observe that most of them are not familiar with SEA. Further, some decision-makers are not highly educated and most of them have a political vision. Most highly educated people consist of academics and have little influence on political decision.

Knowledge and decision are not in the same side. There is a need of redressing such imbalance, and particularly in Brazil most of participants suggest that the first need is to explain the difference between SEA and EIA in order to improve the quality of participation. 
Figure 8 - Questions of group F "is iterative"

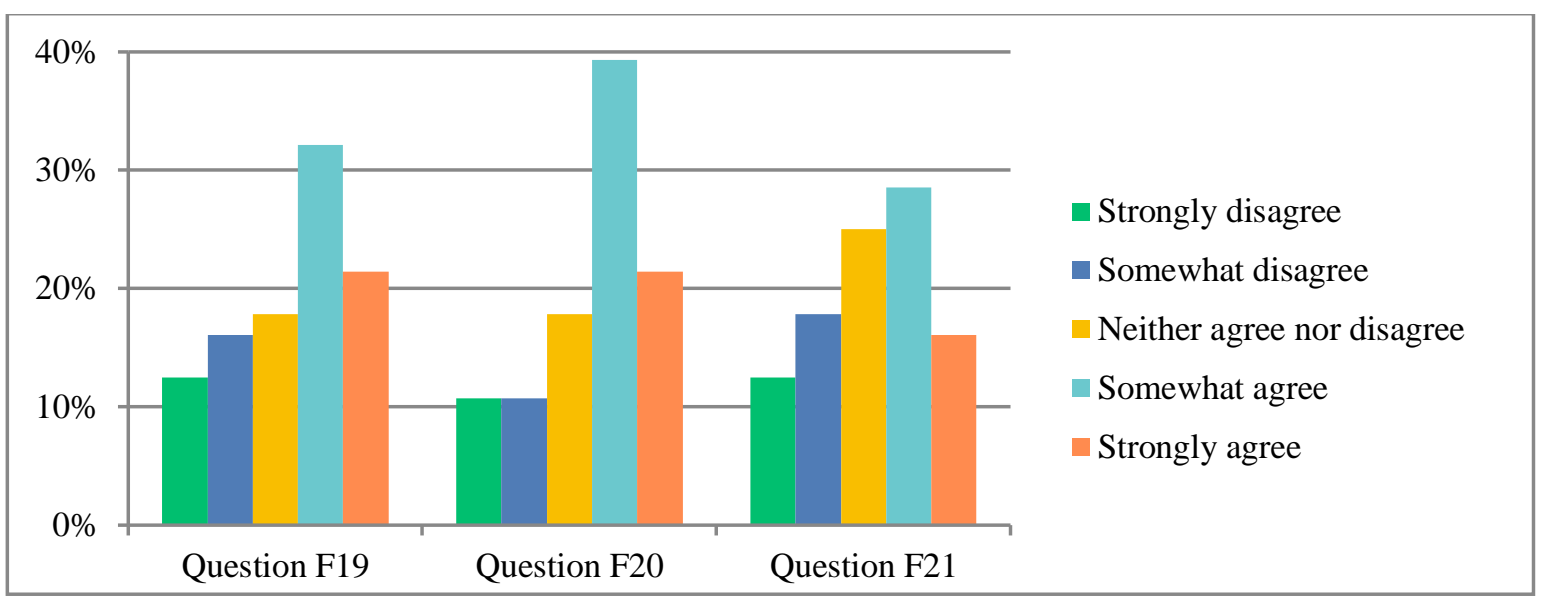

Source: self-elaboration

Results show that most of respondent agree on questions of group F. On question F19, comments of participants refer to the lack of transparency of the process. In the case of SEA\#25, it is reported that information produced was not available for the stakeholders (interviewee \#1 - environmental agency). Actor 4 (consultant) mentions that it is difficult to access necessary information (SEA\#39, SEA\#45, SEA\#65). On question F20, interviewee \#6 (consultant) refers to the lack of political will which pushes the strategic action to the next level of the planning and decision-making process despite the SEA late initiation and little influence (SEA\#1, SEA\#12, SEA\#22, SEA\#23, SEA\#34, SEA\#35, SEA\#39, SEA\#52, SEA\#53). However, SEA\#43, receive positive comments regarding question F20.

The implementation of the Mata Branca Project was based on the SEA, which also served as a guideline to improve the efficiency and effectiveness of on-going projects in the State. Question F21 on capacity building receive divergent comments. A respondent of questionnaire (SEA\#43) mentions that, perhaps, for the first time in the Ceara State, there was a SEA training, which was quite significant, in the sense of awakening to the need to carry out SEA. Interviewee \#3 (consultant) comments that there is no feedback system. Once the funding and environmental license is approved, the SEA is forgotten.

According to interviewee \#1 (environmental agency - SEAs \#23 and \#25), the main outcome of SEA was that SEA induced (mutual) learning processes between consultants, public authorities and the public. Each SEA has its particularity and therefore, provides good experiences on participation in the process. Further, SEA also improves overall awareness of 
involved organization's actions. Particularly SEA \#23 enabled the recognition of the usefulness of SEA as in the last few months, the Minas Gerais state government has shown a growing interest in applying SEA in the forest sector.

Providing information and ensuring early availability of the SEA results are considered important, and the SEA literature has traditionally identified several benefits attached to it, from providing stakeholders with a better understanding of the PPP to greater acceptance of the strategic action (FIDLER; NOBLE, 2012, RUNHAAR; DRIESSEN, 2007; SIMS, 2012). However, providing information and ensuring availability of the assessment results do not guarantee SEA outcomes (MARGATO; SÁNCHEZ, 2014). Although SEA helps to provide information to decision makers, context factors associated to the decision-making process and decision implementation may interfere the achievement of SEA influence on PPP decisionmaking (RUNHAAR; DRIESSEN, 2007). Although little is known about context influence in developing countries (FISCHER; ONYANGO, 2012), there is a need to adapt SEA to the decision-making characteristics where its input can be beneficial.

Figure 9 - Questions of group G "is innovative"

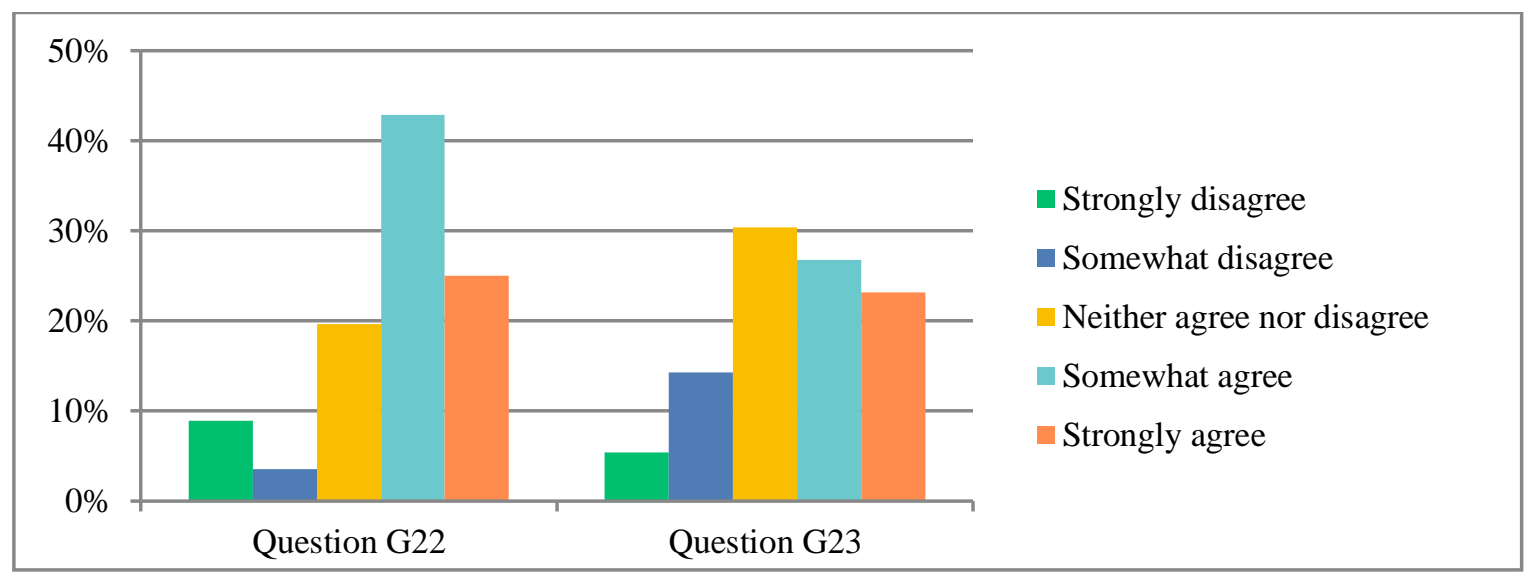

Source: self-elaboration

Most of respondents agree with questions of group G. Comments provide interesting opinions. Interviewee \#9 (proponent) believes that Brazil was innovative in considering Integrated Environmental Assessment comprehensively. The use of these evaluations could bring innovative results for the planning of the various economic sectors (SEA\#28, SEA\#29, SEA\#30, SEA\#31, SEA\#32, SEA\#41, SEA\#42, SEA\#47, SEA\#48, SEA\#54, SEA\#55, 
SEA\#56, SEA\#57 and SEA\#66). On SEA \#43, actor 6 (consultant) mentions that SEA identifies restrictions and potential associated to the strategic action. By doing so, the assessment stimulated more sustainable projects adapted to local realities. On the other hand, interviewee \#3 (consultant) thinks that SEA\#11 could play an important role considering actors involved in the assessment. However it did not fulfill its objectives as it was only conducted to address the MDA's requirements. The government has demonstrated no concern about the issue of sustainability or the choice of the best development option in terms of costs and benefits. SEA could take advantage of such situation in order to identify or stimulate different perspectives.

According to interviewees \#2, \#3, \#5, \#6 (consultants) and 9 (proponent) (SEAs \#1, \#15, \#30, \#31, \#45 and \#63), most of SEAs dedicated the last chapter to recommendations which refer to new research directions or needs, especially public development programs. Considering political pressure, such recommendations are neglected instead of stimulating new research directions or needs. Most of the time, crucial decisions were already made by the time participants were involved and the leeway given to the SEA was limited. However, even in cases where none of the recommendations resulting from the assessment is considered, there is still an opportunity for SEA to have a longer-term, indirect influence. A lengthy time period is needed to realize the influence of an assessment process; thus, participants may not see the value of SEA practices in the short term (TETLOW; HANUSCH, 2012).

Innovation through SEA is little explored so far. However, it is to be noted that SEA functioned as a process facilitator, contributing to the decision making process in which knowledge is produced not only for the sake of legal obligations but also to facilitate a process of frame reflection, consensus-building and joint fact-finding (ACHARIBASAM; NOBLE, 2014; (BROWN; THERIVEL 2000). Literature indicates that SEA is more effective when integrated with the PPP development and decision-making process (BROWN; THERIVEL 2000). In such situation, SEA can make its innovative contribution to the decision-making processes.

\section{Synthesis}

In this section, the aim was to identify SEA outcomes in Brazil and the contextual aspects related to them. Based on questionnaires and interviews, the study method drew from international outcomes for SEA. Results reveal the occurrence of all SEA outcomes even though the context is characterized by resource constraints and economic and political 
pressures, as well as inherent limitations in procedures and legislation. Participants provided important aspects associated with outcomes such as the lack of regulation, political pressures and limited knowledge of SEA.

Positive aspects were also reported. The intense participation of civil society in SEA \#43 resulted in the consideration of public inputs in PPP decisions. The same SEA served as a guideline to improve the efficiency and effectiveness of on-going projects in the State. We conclude that there is room for hope. Certainly more SEA outcomes are occurring in Brazil. As stated by Noble (2013), it is often the case that some outcomes are not identified or realized because of the ad hoc or one-time application of many assessments. Furthermore, SEA outcomes or the value added are often subtle, indirect and unfold over the long-term. The challenge is to ensure that the SEA outcome is perceived, thus the tool can play its role.

\subsection{Intervening aspects on the effectiveness of SEA in Brazil}

In this section, the contextual aspects identified are grouped, presented and discussed according to similarities and taking into account that the understanding of the outcome adopted in this thesis is related to the influence of SEA on decision-making and on the participants/organizations that took part in the SEA and planning process. Please note that the factors are presented randomly and do not reflect any hierarchy or preference.

(i) Lack of SEA regulations and guidance

This study reveals the absence of SEA regulations and legislation as the principal characteristic of SEA in Brazil. Interviewees \#6 (consultant) and 7 (consultant) highlight the institutional setting for the implementation of SEA in Brazil. They mention that the country's legal framework lacks the definition of contextual factors such as where and how the application of SEA is necessary. Therefore, SEA cannot be considered legally accepted as its application is conducted on a voluntary basis. This reflection lends support to the findings of Montaño et al. (2011) that the lack of a legal framework is one of the main characteristics of the SEA in Brazil.

According to interviewee \#6 (consultant), without a legal framework, SEA is systematically required only by MDAs, and randomly required by private companies, state or federal 
governments. SEA is part of the funding policy of a MDA and is meant to safeguard environmental interests and contribute to environmental governance (RICHARDSON; CASHMORE, 2011; CASHMORE; AXELSSON, 2013; CASHMORE et al., 2014). Regarding private initiatives, society and governments, SEA is applied when there is not any other option, mostly when EIA could not support PPPs decision-making.

Montaño et al. (2014), reporting on the institutional framework for the implementation of SEA in Brazil, stressed that the existing legislation is insufficient to clarify contextual factors such as where and how the use of SEA is necessary.

According to Montaño and Fischer (2019, pg. 104), it is expected that SEA guidance would be able to:

(a) establish a minimum standard for the SEA process and its integration into PPP making, and (b) stimulate a better standard than minimum requirements, in particular to the quality of the SEA process and its various associated elements (e.g. consideration of alternatives, use of state-of-the-art methods).

Lack of SEA guidelines and legislation was also found to be the main and common characteristic of most developing countries (ALSHUWAIKHAT, 2005; WALMSLEY; PATEL, 2011; RACHID; FADEL, 2012; MONTAÑO et al., 2014). Several authors discuss the necessity to adopt a legal requirement for SEA. On the one hand, SEA adoption is found to be important to facilitate the SEA application in an institutional system of restricted collaborative planning and powerful interests (HILDÉN et al., 2004). On the other hand, some authors advocate that there is a need for high level commitment and capacity for conducting SEA prior to the tool's introduction in a given country. Without this initial requirement, there is no point in making this tool mandatory (SLUNGE; LOAYZA, 2012; MOTA et al., 2014).

(ii) The influence of key actors on the use of SEA

Interviewees were firstly asked to point out the elements that - according to their perception - motivated the use of SEA in a non-mandatory context. Interviewees \#1 (environmental agency) and \#6 (consultant) emphasized the importance of the role played by key actors who were previously aware of the potential contributions of this instrument to strategic decisionmaking. For example, the SEA prepared for the Minas Gerais Road Programme was requested by the Secretary of Environment of Minas Gerais State ("who was aware of the benefits 
attached to this instrument and played a decisive role in the decision of its application" Interviewee \#2).

Another relevant contextual aspect relates to the diversity of groups of interest that demonstrated some influence on the use of SEA in the country. Interviewee \#6 (consultant) stated: "some years ago, the Federal Audit Court announced the constitution of a group of environmental and social impact specialists as several strategic actions were cancelled due to their associated environmental and social risks". Interviewee \#6 also mentioned the fact that "governments and NGOs have expressed their concern that EIA was not effective. Therefore, there was a need for a more adapted tool to pursue the benefits of an additional layer of assessment in the planning structure". Also, "some institutions have required SEA due to its relevance. For instance, the SEA of the Tourism Development Programme in the North-east (PRODETUR NE) was requested after the Federal Audit Court issued a technical report in 2012 with an explicit recommendation to consider the use of SEA".

Interviewee \#3 (consultant) suggested that "many of the countries that have experimented with SEA at the national level have begun to extend its use due to bilateral development cooperation, which is also the case in Brazil once MDAs financed 26 SEAs in the country".

According to interviewee \#2, "the SEA applied to the Hydroelectric Generation Programme in Minas Gerais enabled the recognition of the usefulness of SEA thereafter. The necessity of SEA was highlighted, and its application was required to support decision-making on hydroelectric expansion in the state of Minas Gerais in terms of development opportunities and conflict management".

(iii) Legacy of project-EIA and environmental licensing

It is recognised that SEA can enable tiering, i.e. the streamlining of project-EIA, providing a means to reduce time and ease the project's approval (UNALAN; COWELL, 2009). Accordingly, interviewees \#1 (environmental agency), \#4, \#5 and \#6 (consultants) attributed the application of SEA to the perspective of a facilitated project-EIA approval. Proponents from the private sector (interviewees \#8 and \#9) said that entrepreneurs resorted to SEA to reduce environmental risks and uncertainties, thus corroborating what was previously observed by Marshall and Fischer (2006) with regards to the use of SEA in the private sector. 
The findings reveal the strong influence of the environmental license culture, in which SEA is applied to promote the environmental dimension into the decision-making process in order to ease the approval of related projects. Indeed, interviewees \#1, \#7 and \#8 (respectively an environmental agency's representative, consultant and proponent) affirmed that a facilitated project-EIA process was the main objective of SEA applied to large projects, as already reported in the literature (MALVESTIO; MONTAÑO, 2013; SÁNCHEZ; SILVA-SÁNCHEZ, 2008).

In this respect, empirical evidence suggests that there is little influence on the strategic levels of decision-making (MALVESTIO; MONTAÑO, 2013; MALVESTIO; MONTAÑO, 2019), possibly due to the linkage between SEA recommendations and the final decision being virtually non-existent in the absence of a clear decision-making framework (MARGATO; SÁNCHEZ, 2014). This reinforces the idea that there is a growing appreciation of the role of SEA, if not to explicitly support more environmentally sound policies, plans and programmes (PPP), then at least to implicitly provide information to other levels of decision-making.

One of the few exemptions was related to the development of the Metropolitan Ringroad, a large highway project built in the outskirts of Sao Paulo city region. Considering the lack of formal requirements for SEA in São Paulo State, SEA emerged as an alternative to ease the approval of the project, which was immersed in controversy due to the environmental and social impact it would have on the areas that were going be affected. It has challenged the hypothesis of independent, self-standing sections of the road project and suggested the integration to other actions, thus inducing the project's reformulation to consider multi-sectorial integrated actions (SÁNCHEZ; SILVA-SÁNCHEZ, 2008).

(iv) Learning

Despite the fact that SEA may provide opportunities for broader institutional, individual and social learning (KIDD et al., 2011), thus contributing to the improvement of SEA systems, the uncertainty with regards to further developments of the SEA system in Brazil was considered by interviewee \#9 (proponent) as a burden linked to the rapid changes in political willingness at each electoral cycle. In this respect, it was emphasized that "government strategies and political actions change according to the arrival of a new government and this normally implies in different public policies to stimulate development". In a similar way, Malvestio and Montaño 
(2019) considered the transience of public administrators as one of the constraints to the development of the SEA system related to the planning context in Brazil.

Regarding the SEA of the Programme for Tourism Development in the North Coast, in spite of restricted public participation and the lack of coordination and synergy between the federal and state governments as reported by Silva et al. (2014), there was an opportunity to improve communication between stakeholders and enhance institutional learning through the Ministry of Tourism's commitment and involvement in the whole process.

According to Unalan and Cowell (2009), actors involved in the SEA process may acquire deeper knowledge of the tool. Therefore, there is a need for improved follow-up on SEA to ensure learning through practice (ACHARIBASAM; NOBLE, 2014). MONTAÑO et al. (2013) noted the slow but constant improvement in the procedural performance of Brazilian SEAs.

(v) Public participation

Regarding public participation, the literature reports that the involvement of the public is usually very limited in Brazil (MALVESTIO; MONTAÑO, 2013; MARGATO; SÁNCHEZ, 2014) with a poor involvement of stakeholders (MALVESTIO; MONTAÑO, 2013). Concerning this topic, interviewee \#5 (consultant) argued that "whilst it is necessary to explicitly address public concerns, there is also a need for educating the public as I was able to observe that most of the participants were not familiar with SEA". Along similar lines, interviewees \#5 and \#7 (both consultants) and \#9 (proponent) argued that despite a considerable effort to involve the public during the course of the consultation period, few responses were received. There is clearly a need for setting the purposes and meaning of public participation in SEA processes, as largely found in the international literature (ACHARIBASAM; NOBLE, 2014; REGA; BALDIZZONE, 2015; THERIVEL; MINAS, 2002; WALKER et al., 2013).

Broadly speaking, SEAs were rarely introduced early enough in planning processes. However, they still found room to influence decisions regarding social and political issues. In this regard, interviewee \#6 stated that "[thanks to the SEA process] civil society participated in the whole process acting as controller. Workshops were recurrently organized to keep the public updated, and this resulted in better communication and cooperation of authorities, individuals, other institutions and organisations. Furthermore, the stakeholders' interests were represented in the final programme". In a similar way, according to Acharibasam and Noble (2014), SEA in 
Canada provided information to better align the PPPs with the stakeholders' concerns and interests.

(vi) Influence on other plans and projects

Other outcomes include the use of SEA findings beyond their specific decision-making context. For example, recommendations to the São Paulo Metropolitan Ringroad Programme were considered in subsequent project-EIAs (SÁNCHEZ; SILVA-SÁNCHEZ, 2008). In a similar way, the SEA applied to Corumbá Mining and Industrial District informed other plans and the environmental management strategies for the industrial complex (SILVA et al., 2014). Also, concerning the SEA of the Mata Branca Project (Caatinga Biome) in 2010, interviewee \#3 observed that even after the end of the project, strategies recommended in the study were adopted and new approaches developed for the continuity of sustainable interventions in the Caatinga biome.

(vii) Data availability

Findings show that the lack of relevant data is also a characteristic of the Brazilian SEA system. Interviewees \#1 (environmental agency) and \#2 (consultant) observed that the lack of data induces a superficial analysis of environmental issues and consequently hinders the development and implementation of sustainability objectives. However, even when data are available, there is a need to clearly specify what data to use and why (JOÃO, 2007), which was also recognised by interviewee \#2 ("from a pragmatic point of view, data are crucial to conduct a SEA; from a quality perspective, it is important to choose adequate data as they influence the findings and outcomes of the SEA process").

Several authors report the lack of data as a factor negatively influencing the use of SEAs. Data issues are fundamental in terms of what the SEA process is about. According to actors, SEA data are usually based on information gathered from secondary sources. It is important to note that there is no formal mandate for SEA in Brazil and the country lacks a SEA database which exacerbates the difficulty of accessing data used in previous studies. 
This is an issue that lies at the heart of the SEA process. From a pragmatic point of view, data are fundamental as they are needed in order to carry out a SEA. From a quality perspective, the choice of data is also crucial as different data might result in different outcomes of the SEA process (PARTIDÁRIO, 2007).

Table 13 summarizes the findings presented above. The table particularly highlights if the factors have any influence on the occurrence of outcomes.

Table 13 - Influencing relation between outcomes and criteria (follows)

\begin{tabular}{|c|c|c|c|c|c|c|c|}
\hline & Factor 1 & Factor 2 & Factor 3 & Factor 4 & Factor 5 & Factor 6 & Factor 7 \\
\hline Outcome 1 & $\sqrt{ }$ & $\sqrt{ }$ & $\neq$ & $\sqrt{ }$ & $x$ & $\sqrt{ }$ & $\neq$ \\
\hline Outcome 2 & $\sqrt{ }$ & $\sqrt{ }$ & $\sqrt{ }$ & $\neq$ & $x$ & $\neq$ & $\neq$ \\
\hline Outcome 3 & $\sqrt{ }$ & $\sqrt{ }$ & $\sqrt{ }$ & $\sqrt{ }$ & $x$ & $\sqrt{ }$ & $\sqrt{ }$ \\
\hline Outcome 4 & $\sqrt{ }$ & $\sqrt{ }$ & $\neq$ & $\sqrt{ }$ & $x$ & $\sqrt{ }$ & $\neq$ \\
\hline Outcome 5 & $\sqrt{ }$ & $\sqrt{ }$ & $\sqrt{ }$ & $\sqrt{ }$ & $x$ & $\sqrt{ }$ & $\neq$ \\
\hline Outcome 6 & $\sqrt{ }$ & $\sqrt{ }$ & $\neq$ & $\sqrt{ }$ & $x$ & $\sqrt{ }$ & $\neq$ \\
\hline Outcome 7 & $\sqrt{ }$ & $\sqrt{ }$ & $\sqrt{ }$ & $\sqrt{ }$ & $x$ & $\sqrt{ }$ & $\neq$ \\
\hline Outcome 8 & $\sqrt{ }$ & $\sqrt{ }$ & $\sqrt{ }$ & $\sqrt{ }$ & $x$ & $\sqrt{ }$ & $\neq$ \\
\hline Outcome 9 & $\sqrt{ }$ & $\sqrt{ }$ & $\sqrt{ }$ & $\sqrt{ }$ & $x$ & $\sqrt{ }$ & $\sqrt{ }$ \\
\hline Outcome 10 & $\sqrt{ }$ & $\sqrt{ }$ & $\sqrt{ }$ & $\sqrt{ }$ & $x$ & $\sqrt{ }$ & $\neq$ \\
\hline Outcome 11 & $\sqrt{ }$ & $\neq$ & $\sqrt{ }$ & $\neq$ & $x$ & $\sqrt{ }$ & $\neq$ \\
\hline Outcome 12 & $\sqrt{ }$ & $\sqrt{ }$ & $\sqrt{ }$ & $\neq$ & $x$ & $\sqrt{ }$ & $\neq$ \\
\hline Outcome 13 & $\sqrt{ }$ & $\sqrt{ }$ & $\sqrt{ }$ & $\neq$ & $x$ & $\neq$ & $\neq$ \\
\hline
\end{tabular}


$\begin{array}{lllllll}\text { Factor } 1 & \text { Factor } 2 & \text { Factor } 3 & \text { Factor } 4 & \text { Factor } 5 & \text { Factor } 6 & \text { Factor } 7\end{array}$

\begin{tabular}{|c|c|c|c|c|c|c|c|}
\hline Outcome 14 & $\sqrt{ }$ & $\sqrt{ }$ & $\sqrt{ }$ & $\neq$ & $x$ & $\sqrt{ }$ & $\neq$ \\
\hline Outcome 15 & $\sqrt{ }$ & $\sqrt{ }$ & $\sqrt{ }$ & $\sqrt{ }$ & $x$ & $\sqrt{ }$ & $\sqrt{ }$ \\
\hline Outcome 16 & $\sqrt{ }$ & $\neq$ & $\sqrt{ }$ & $\sqrt{ }$ & $x$ & $\sqrt{ }$ & $\neq$ \\
\hline Outcome 17 & $\sqrt{ }$ & $\sqrt{ }$ & $\sqrt{ }$ & $\sqrt{ }$ & $x$ & $\sqrt{ }$ & $\sqrt{ }$ \\
\hline Outcome 18 & $\sqrt{ }$ & $\sqrt{ }$ & $\sqrt{ }$ & $\sqrt{ }$ & $x$ & $\sqrt{ }$ & $\sqrt{ }$ \\
\hline Outcome 19 & $\sqrt{ }$ & $\sqrt{ }$ & $\sqrt{ }$ & $\sqrt{ }$ & $x$ & $\sqrt{ }$ & $\neq$ \\
\hline Outcome 20 & $\sqrt{ }$ & $\sqrt{ }$ & $\sqrt{ }$ & $\sqrt{ }$ & $x$ & $\sqrt{ }$ & $\neq$ \\
\hline Outcome 21 & $\sqrt{ }$ & $\sqrt{ }$ & $\sqrt{ }$ & $\sqrt{ }$ & $x$ & $\sqrt{ }$ & $\neq$ \\
\hline Outcome 22 & $\sqrt{ }$ & $\sqrt{ }$ & $\sqrt{ }$ & $\sqrt{ }$ & $x$ & $\sqrt{ }$ & $\neq$ \\
\hline Outcome 23 & $\sqrt{ }$ & $\sqrt{ }$ & $\sqrt{ }$ & $\sqrt{ }$ & $x$ & $\sqrt{ }$ & $\neq$ \\
\hline
\end{tabular}

$\sqrt{ }$ : Outcome has positive influence on the criteria occurrence $\mathcal{X}$ : Outcome has negative influence on the criteria occurrence $\neq$ : Outcome does not have influence on the criteria occurrence 
5.5 Considerations about the methodological approach for a systematic identification of SEA outcomes: Strengths and weaknesses

Regarding the first stage, criteria for identification of SEA outcomes resulted in a high number, for a total of 269 outcomes. Of them, some merged due to duplication and grouping, however it remained a total of 98 outcomes. Such number was considered high as the respondents would identify the occurrence of each outcome given the need to develop a questionnaire. It is to be noted that a good questionnaire should be as short as possible (MATTHEWS; ROSS, 2010). Therefore, the list of SEA outcomes was replaced with the IAIA performance criteria (See IAIA, 2002) as each outcome could be linked to the IAIA performance criteria. Outcomes without explicit link with IAIA criteria constitute new criteria.

In the second stage, a first step was to list SEAs already applied. It is important to highlight that, there is no formal mandate for SEA in Brazil and the country lacks a SEA database which exacerbates the difficulty of accessing all SEA documents. However, we gathered 58 number of reports out of the 68 SEAs identified.

Furthermore, still in the second stage, we conducted a snapshot approach which consisted of a one-time survey based on a literature review, report analysis, questionnaire application and informal conversation. The main advantage of this methodological approach is its easy and quick application over a short period of time, which normally fits well with the time available by the participants, thus reducing their withdrawal. Further, it is also affordable in economic terms; therefore, it can be applied to a larger sample (MATTHEWS; ROSS, 2010).

However, the approach presents some limitations associated with the identification of actors involved in the processes of SEA, as the search for actors contact was made by internet, telephone and by asking actors to refer other acknowledged contacts. Considering criteria used to find actors, it was expected that all actors contacted have a computer with internet connection available or a telephone. It is to be noted that SEA processed such as Regional environmental assessment of the Ceará state water resources integrated management program and SEA of Gasbol pipeline occurred in late 90s when the idea of electronic mail was quite foreign and mobile devices were scarce. Therefore, it was difficult to reach actors involved early SEA processes, as their contact are not available on SEA reports. It was also difficult to reach several actors as some SEA reports only provide names of institutions. Once contacted, those institutions informed that some actors are retired or are not working there anymore. 
Moreover, the approach presents some difficulties to overcome. We found difficult to handle the identification of the different types of actors involved in the processes of SEA. Results show that actors and institutions vary from case to case. This may be attributed to the lack of SEA legislation in Brazil with actors explicitly mentioned. Under formal SEA requirements, actors identification would be easier and quicker (ACHARIBASAM; NOBLE, 2014; ROZASVÁSQUEZ et al., 2017).

Regarding the third stage, the identification resulted in 906 actors. The questionnaire was sent to 746 respondents whose e-mail and telephone could be identified. The main challenge was associated to the need to deal with large volumes of textual data due to the high number of actors involved in SEA processes. 


\section{Conclusion}

This thesis aimed to explore the extent to which the context may influence the effectiveness of an SEA based on perceived SEA outcomes. Based on outcomes reported in SEA literature and IAIA performance criteria, questionnaires were applied and subsequently interviews were conducted with SEA participants. Findings in phase one of the research show that issues such as health, innovative strategies and approaches to sustainability deserve special attention within IAIA performance criteria. In the second phase, results reveal that participants include public authorities, consultancies acting as coordinator, MDAs and the public. Consultants and the public were found to be the most numerous groups of actors, while representatives of MDA were the lowest. The results of the questionnaires and interviews results reveal the occurrence of the entire list of SEA outcomes, despite limitations in procedures and legislation, resource constraints, and economic and political pressures. Participants report interesting context characteristics such as learning and lack of SEA regulations and guidance.

In general, among participants there appears to be a certain level of confidence about the nature of SEA, how SEA fits within the planning, and SEA added value to both strategic and projectbased impact assessment practices and decisions. However, there are two contextual factors which they find to be relevant to the realization of useful knowledge. These have to do with influence of key actors and lack of regulations. It can therefore be concluded that SEA practice is in need of improvement in term of setting clearly the role of actors. The research suggests a need for SEA to be applied as part of the planning process as SEA can facilitate the accomplishment of a legitimate selection of policy ambitions, a process of mutual learning between stakeholders with different perceptions and the realization of a jointly agreed-upon body of knowledge.

From a research perspective, the results of this thesis suggest that contextual factors truly influence the occurrence of outcomes. An analysis of findings indicates that the role of SEA in consent and design decisions is limited, due primarily to passive integration with the decision processes it is intended to inform. Outcomes are not always clear and the influence of SEA on decision making is said to be limited in many cases. It is concluded that efficient SEA outcomes can be obtained by providing an adequate set of agreed rules for interaction and decisionmaking. 
There are a number of additional conditions which are also relevant to the realization of outcomes. These have to do with: the time that is likely to elapse before outcomes clearly manifest; the necessity of engaging with diverse stakeholders; and the practical difficulties associated with Governments, proponents and other stakeholders working collaboratively in a model of shared responsibility to manage the delivery of outcomes.

Evaluating SEA, beyond basic input or procedural characteristics, is thus a complex task. An SEA implemented in full compliance with a legislation or directive, and adopting the best methodological process, can have little to no outcome. At the same time, it is possible that an SEA that does not adhere to 'best practice' can have a significant outcome. Further, the expectations of what SEA should deliver vary considerably. Nevertheless, it is recommended to focus more attention on SEA outcomes, more importantly, on the longer term, often indirect, impacts and influences of SEA. Given the contextual factors of SEA in Brazil, it is postulated that focusing on promoting positive outcomes represents a more productive strategy for advancing SEA in the immediate future.

This thesis provides a deep analysis of the occurrence of outcomes in Brazil and may thus provide a basis for SEA practitioners, competent authorities and stakeholders to decide upon the specific goal(s) and to consider contextual factors prior to the assessment process, thereby hopefully delivering desired outcomes. 


\section{Note}

Parts of this thesis has already been published in a peer review journal.

See TSHIBANGU, G. M.; MONTANO, M. Outcomes and contextual aspects of strategic environmental assessment in a non-mandatory context: the case of Brazil. Impact Assessment and Project Appraisal, v. 3, 2019. 


\section{References}

ACHARIBASAM, J. B.; NOBLE, B. F. Assessing the impact of strategic environmental assessment. Impact Assessment and Project Appraisal, v. 32, n. 3, p. 177-187, 2014.

ALAMEDDINE, M.; NAJA, F.; ABDEL-SALAM, S.; MAALOUF, S.; MATTA, C.

Stakeholders' perspectives on the regulation and integration of complementary and alternative medicine products in Lebanon: a qualitative study. BMC Complementary and Alternative Medicine, v. 11, n. 71, p. 1-10, 2011.

ALSHUWAIKHAT, H. M. Strategic environmental assessment can help solve environmental impact assessment failures in developing countries. Environmental Impact Assessment Review, p. 307-317, 2005.

ANDRADE, A. L.; SANTOS, M. A. Hydroelectric plants environmental viability: Strategic environmental assessment application in Brazil. Renewable and Sustainable Energy Reviews, v. 52, p. 1413-1423. 2015.

ANNANDALE, D.; BAILEY, J.; OUANO, E.; EVANS, W.; KING, P. The potential role of Strategic Environmental Assessment in the activities of Multi-lateral Development Banks, Environmental Impact Assessment Review, v. 21, p. 407-429, 2001.

BARKER, A. Strategic Environmental Assessment (SEA) as a Tool for Integration within Coastal Planning. Journal of Coastal Research, v. 22, n. 4, p. 946-950, 2006.

BASTOS, M. M. Avaliação Ambiental Estratégica no contexto brasileiro: efetividade e desafios jurídico-institucionais. Dissertação (Mestrado) - Escola de Direito de São Paulo da Fundação Getulio Vargas, 2015.

BAUER, M. W.; GASKELL, G. Pesquisa Qualitativa com Texto, Imagem e Som - Um manual prático, $2^{\mathrm{a}}$ ed. Editora Vozes, Petrópolis, 2002.

BERG, B. L. Qualitative research methods for the social sciences. 4th ed. 2001.

BHATTACHERJEE, A. Social science research: principles, methods, and practices. Florida: USF Open Access Textbooks Collection. Book 3, 2012.

BINA, O. A critical review of the dominant lines of argumentation on the need for strategic environmental assessment. Environmental Impact Assessment Review, v. 27, p. 585-606, 2007.

BODIN, Ö; CRONA, B. Community-based management of natural resources-exploring the role of social capital and leadership in a rural fishing community. World Development, v 36, p. 2763-2779, 2008.

BODIN, Ö; CRONA, B. I. The role of social networks in natural resource governance: What relational patterns make a difference? Global Environmental Change, v. 19, p. 366-374, 2009.

BRAGAGNOLO, C.; GENELETTI, D.; FISCHER, T. B. Cumulative effects in SEA of spatial plans - evidence from Italy and England. Impact Assessment and Project Appraisal, v. 30, n. 2, p. 100-110, 2012.

BREEZE, C; LOCK, K, editors. Health impact assessment as part of strategic environmental assessment. Copenhagen: WHO Regional Office for Europe. Available at: http://www.apho.org.uk/resource/item.aspx?RID=92308, 2001 [accessed 16.04.17]. 
BROWN, A.L.; THÉRIVEL, R. Principles to guide the development of strategic environmental assessment methodology. Impact Assessment and Project Appraisal, v.18, n.3, p.183-189, 2000.

BRYMAN, A. Social Research Methods, Second ed. Oxford University Press, New York, 2012.

BURT, R. S. Structural holes and good ideas. American Journal of Sociology, v. 110, n. 2, p. 349-399, 2004.

BUUREN, A. V.; NOOTEBOOM, S. The success of SEA in the Dutch planning practice How formal assessments can contribute to collaborative governance, Environmental Impact Assessment Review, v. 30, p. 127-135, 2010.

CASHMORE, M.; AXELSSON, A. The mediation of environmental assessment's influence: What role for power?, Environmental Impact Assessment Review, v. 39, p. 5-12, 2013.

CASHMORE, M.; GWILliAM, R.; MORGAN, R. K.; COBB, D.; BOND, A. J. The interminable issue of effectiveness: Substantive purposes, outcomes and research challenges in the advancement of environmental impact assessment theory. Impact Assessment and Project Appraisal, v. 22, n. 4, p. 295-310, 2004.

CASHMORE, M.; RICHARDSON, T.; AXELSSON, A. Seeing power in international development cooperation: environmental policy integration and the World Bank. Transactions of the Institute of British Geographers, v. 39, n. 1, 2014.

CHANCHITPRICHA, C; BOND A. Conceptualizing the effectiveness of impact assessment processes. Environmental Impact Assessment Review, v; 43, p. 65-72, 2013.

COMMISSION OF THE EUROPEAN COMMUNITIES (CEC). Directive 2001/42/EC on the assessment of the effects of certain plans and programmes on the environment, 2001

CONTICELLI, E.; TONDELLI, S. Application of Strategic Environmental Assessment to EcoIndustrial Parks: Raibano Case in Italy, Journal of Urban Planning and Development, v. 139, n. 3, 2013.

CORBIN, J.; STRAUSS, A. Basics of qualitative research: techniques and procedures for developing grounded theory (3rd edition) Sage, Thousand Oaks, CA (2008).

CUN-KUAN, B.; YONG-SEN, A.; JIN-CHENG, S. Framework and operational procedure for implementing Strategic Environmental Assessment in China. Environmental Impact Assessment Review. v. 24, p. 27-46, 2004.

DALAL-CLAYTON, B.; SADLER, B. Strategic environmental assessment: a sourcebook and reference guide to international experience. London. Earthscan. 2005. 470 p.

DOUGLAS, M. J.; CARVER, H.; KATIKIREDDI, S. V. How well do strategic environmental assessments in Scotland consider human health? Public Health, v. 125, p. 585 $-591,2011$.

DUSIK, J.; XIE, J. Strategic environmental assessment in East and Southeast Asia: A Progress Review and Comparison of Country Systems and Cases. Sustainable Development Department, East Asia and Pacific Region, The World Bank, Washington, D.C. 2009

ELO, S.; KYNGÄS, H. The qualitative content analysis process. Journal of Advanced Nursing, v. 62, p. 107-115, 2007. 
ESTEVES, A. O.; SOUZA, M. P. Avaliação Ambiental Estratégica e as Áreas de Proteção Ambiental. Engenharia Sanitária e Ambiental, Edição Especial, p. 77-86, 2014.

FISCHER, T. B. Benefits arising from SEA application: a comparative review of North West England, Noord-Holland, and Brandenburg-Berlin. Environmental Impact Assessment Review. v. 19, p. 143-173, 1999.

FISCHER, T. B. Strategic Environmental Assessment in post-modern times, Environmental Impact Assessment Review. v. 23, p. 155-170, 2003.

FISCHER, T. B. The Theory and Practice of Strategic Environmental Assessment: Towards a More Systematic Approach. London: Earthscan, 2007. 186p.

FISCHER, T. B.; MATUZZI, M.; NOWACKI, J. The consideration of health in strategic environmental assessment (SEA). Environmental Impact Assessment Review, v. 30, p. 200-210, 2010.

GALLARDO, A. L. C. F.; BOND, A. Capturing the implications of land use change in Brazil, Environmental Impact Assessment Review, v. 31, Issue 3, p. 261-270, 2011.

GAO (United States General Accounting Office). Content analysis: a methodology for structuring and analyzing written material. Washington, DC: 1996.

GILES, D. C. Advanced Research Methods in Psychology. Taylor and Francis, Florence, 2013.

GONZÁLEZ, A.; THERIVEL, R.; FRY, J.; FOLEY, W. Advancing practice relating to SEA alternatives. Environmental Impact Assessment Review, v. 53, p. 52-63, 2015.

HAMBLIN, P. Environmental integraion through strategic environmental assessment: prospects in Europe, European Environment, v. 9, p. 1-9, 1999.

HEGAZY, I. R. Integrating strategic environmental assessment into spatial planning in Egypt. Environmental Development, v. 15, p. 131-144, 2015.

HERRERA, R. J. Strategic Environmental Assessment: the need to transform the environmental assessment paradigms, Journal of Environmental Assessment Policy and Management. v. 9, n. 2, p. 211-234, 2007.

HILDING-RYDEVIK, T.; BJARNADÓTTIR, H. Context awareness and sensitivity in SEA implementation. Environmental Impact Assessment Review, v. 27, p. 666-684, 2007.

HIPONDOKA, M. H. T.; DALAL-CLAYTON, D. B., GILS, H. V. Lessons learnt from voluntary strategic environmental assessments (SEAs) in Namibia. Impact Assessment and Project Appraisal, n. 34, p. 199-213, 2016.

INTERNATIONAL ASSOCIATION FOR IMPACT ASSESSMENT (IAIA), Strategic Environmental Assessment Performance Criteria, Special Publication Series No. 1, 2002.

JACKSON,T.; ILLSLEY, B. Strategic Environmental Assessment as a Tool of Environmental Governance: Scotland's Extension of the European Union SEA Directive. Journal of Environmental Planning and Management, v. 49, n. 3, p. 361 - 383, 2006.

JHA-THAKUR, U.; GAZZOLA, P.; PEEL, D.; FISCHER, T.; KIDD.; S. Effectiveness of strategic environmental assessment - the significance of learning. Impact Assessment and Project Appraisal. v. 27, n. 2, p. 133-44, 2009.

JOÃO, E. A research agenda for data and scale issues in Strategic Environmental Assessment (SEA). Environmental Impact Assessment Review, v. 27, p. 479-491, 2007. 
JOÃO, E; MCLAUCHLAN, A. Would you do SEA if you didn't have to? - Reflections on acceptance or rejection of the SEA process. Impact Assessment and Project Appraisal, n. 32, v. 2, p. 87-97, 2014.

KIRCHHOFF, D.; McCARTHY, D.; CRANDALL, D.; WHITELAW, G. Strategic environmental assessment and regional infrastructure planning: the case of York Region, Ontario, Canada. Impact Assessment and Project Appraisal, v. 29, n. 1, p. 11-26, 2011. KONTIĆ, B.; DERMOL, U. Confronting reality in strategic environmental assessment in Slovenia - Costs and benefits. Environmental Impact Assessment Review, v. 50, p. 4252, 2015.

KØRNØV, L. Strategic Environmental Assessment as catalyst of healthier spatial planning: The Danish guidance and practice. Environmental Impact Assessment Review, v. 29, p. 60-65, 2009.

KØRNØV, L.; THISSEN, W. A. H. Rationality in decision- and policy-making: implications for strategic environmental assessment. Impact Assessment and Project Appraisal, v. 18, n. 3, p. 191-200, 2000.

KRIPPENDORFF, K., Content Analysis: An Introduction to Its Methodology. 2nd ed. Sage Publications Inc, Thousand Oaks, California, 2003.

LARSEN, S. V.; Kørnøv, L.; Driscoll, P. Avoiding climate change uncertainties in Strategic Environmental Assessment. Environmental Impact Assessment Review, v. 43, p. 144-150, 2013.

LEE, N.; WALSH, F. Strategic environmental assessment: an overview. Project Appraisal, v. 7, n. 3, p. 126-136, 1992.

LEMOS, C. C.; SOUZA, M. P. Avaliação Ambiental Estratégica para Gestão Municipal do Turismo: um estudo no município de Bueno Brandão, MG (Strategic Environmental Assessment for Municipal Tourism Planning: a case study in Bueno Brandão - MG), Turismo em análise, v. 21, n. 3, 2010.

LIETZ, P. Research into questionnaire design: a summary of the literature. International Journal of Market Research, v. 52, n. 2, p. 249-272, 2010.

LIOU, M.; Yu, Y. Development and implementation of Strategic Environmental Assessment in Taiwan. Environmental Impact Assessment Review, v. 24, p. 337-350, 2004.

LOAYZA, F. Strategic Environmental Assessment in the World Bank, Washington DC, 116 p. 2012.

LOBOS, V.; PARTIDARIO, M. Theory versus practice in Strategic Environmental Assessment (SEA). Environmental Impact Assessment Review, v. 48, p. 34-46, 2014.

MALVESTIO, A. C. Análise da efetividade da Avaliação Ambiental Estratégica como instrumento de política ambiental no Brasil. Dissertação apresentada à Escola de Engenharia de São Carlos, Universidade de São Paulo, como pré-requisito à obtenção do título de Mestre em Ciências da Engenharia Ambiental. 2013.

MALVESTIO, A. C.; MONTAÑO, M. Effectiveness of Strategic Environmental Assessment applied to renewable energy in Brazil. Journal of Environmental Assessment Policy and Management, v. 15, n. 2, 2013.

MALVESTIO, A. C.; MONTAÑO, M. From medicine to poison: how flexible strategic environmental assessment may be? Lessons from a non-regulated SEA system. Impact Assessment and Project Appraisal, v. 37, n. 5, 2019. 
MARGATO, V.; SÁNCHEZ, L. E. Quality and outcomes: a critical review of Strategic Environmental Assessment in Brazil. Journal of Environmental Assessment Policy and Management, v. 16, n. 2, 2014.

MARSHALL, R.; FISCHER, T. B. Regional electricity transmission planning and tiered SEA in the UK - The case of ScottishPower. Journal of Environmental Planning and Management, v. 49, p. 279-299, 2006.

MASCARENHAS, A.; RAMOS, T. B.; HAASE, D.; SANTOS, R. Ecosystem services in spatial planning and strategic environmental assessment - A European and Portuguese profile. Land Use Policy, v. 48, p. 158-169, 2015.

MATTHEWS, B; ROSS, L. Research Methods: A practical guide for the social sciences. Harlow: Pearson, 1st ed. 2010.

MEYER, M. D; MILLER, E. J. Urban Transportation Planning: A Decision-oriented Approach, McGraw-Hill, New York, 1984.

MONTAÑO, M.; OPPERMANN, P. A.; MALVESTIO, A. C. Institutional Learning by SEA Practice in Brazil. UVP report, v. 27, p. 201-206, 2013.

MONTAÑO, M.; OPPERMANN, P.; MALVESTIO, A. C. An overview of the current practice of SEA in Brazil. Working paper, 31st Annual Meeting of the International Association for Impact Assessment. Puebla, 2011.

MULDER, J. D. The Protocol on Strategic Environmental Assessment: A Matter of Good Governance. Review of European Community \& International Environmental Law, v. 20, n. 3, 2011.

NEUENDORF, K. The content analysis guidebook. Thausand Oaks, CA: Sage, 2002.

NG, K. L.; OBBARD, J. P. Strategic environmental assessment in Hong Kong. Environment International, v. 31, p. 483-492, 2005.

NOBLE, B. F. Auditing strategic environmental assessment practice in Canada. Journal of Environmental Assessment Policy and Management, v. 5, n. 2, p. 127-47, 2003.

NOBLE, B. F. Integrating Strategic Environmental Assessment with Industry Planning: A Case Study of the Pasquai-Porcupine Forest Management Plan, Saskatchewan, Canada.

Environmental Management, v. 33, n. 3, p. 401-411, 2004.

NOBLE, B. F. Promise and dismay: the state of strategic environmental assessment systems and practices in Canada. Environmental Impact Assessment Review, v. 29, n. 1, p. 66-75, 2009.

NOBLE, B.; KETILSON, S.; AITKEN, A.; POELZER, G. Strategic environmental assessment opportunities and risks for Arctic offshore energy planning and development, Marine Policy, n. 39, p. 296-302, 2013.

NOOTEBOOM, S. Environmental assessments of strategic decisions and project decisions: interactions and benefits. Impact Assessment and Project Appraisal, v. 18, n. 2, p. 151-160, 2000 .

OBERLING, D. F.; LA ROVERE, E. L.; SILVA, H. V. O. SEA making inroads in land-use planning in Brazil: The case of the Extreme South of Bahia with forestry and biofuels. Land Use Policy, v. 35, p. 341-358, 2013.

OLIVEIRA, I. S. D., MONTAÑO, M., SOUZA, M. P. Avaliação Ambiental Estratégica.

São Carlos: Suprema. 2009. 
OPPERMANN, P. de A. Estudo da Avaliação Ambiental Estratégica no Brasil em perspective comparada. Dissertação (Mestrado) - Universidade de São Paulo, EESC, São Carlos, 2012. 108 p.

OPPERMANN, P.; MONTAÑO, M. Strengths and weaknesses of SEA in Brazil. In: 31nd Annual Conference of the International Association for Impact Assessment: Impact Assessment and Responsible Development for Infrastructure, Business and Industry, 2011, Puebla. Draft papers.

OWENS, S.; COWELL, R. Governing space: planning reform and the politics of sustainability. Environ Plann C Gov Policy. v. 24, p. 403-21, 2006.

PARTIDÁRIO, M. R. Elements of an SEA framework - improving the added-value of SEA. Environmental Impact Assessment Review, v. 20, p. 647-663, 2000.

PARTIDÁRIO, M. R. Scales and associated data - What is enough for SEA needs ?

Environmental Impact Assessment Review, v. 27, p. 460-478, 2007.

PARTIDÁRIO, M. R. Strategic Environmental Assessment: key issues emerging from recent practice. Environmental Impact Assessment Review, v. 16, p. 31-55, 1996.

PARTIDÁRIO, M. R.; COUTINHO, M. The Lisbon new international airport: The story of a decision-making process and the role of Strategic Environmental Assessment.

Environmental Impact Assessment Review, v. 31, p. 360-367, 2011.

PARTIDARIO, M. R.; GOMES, R. C. Ecosystem Services inclusive Strategic Environmental Assessment. Environmental Impact Assessment Review, v. 40, p. 36-46, 2013.

PELLIN, A.; LEMOS, C. C.; TACHARD, A.; OLIVEIRA, I. S. D.; SOUZA, M. P. Avaliação Ambiental Estratégica no Brasil: considerações a respeito do papel das agências multilaterais de desenvolvimento. Engenharia Sanitária e Ambiental, v. 16, n.1, p. 27-36, 2011.

PETERSON, K. The role and value of SEA in Estonia: stakeholders' perspectives. Impact Assessment and Project Appraisal, v. 22, n. 2, p. 159-165, 2004.

PIZELLA, D. G.; Souza, M. P. Avaliação Ambiental Estratégica de Planos de Bacias Hidrográficas. Engenharia Sanitária e Ambiental, v.18, n.3, p. 243-252, 2013.

POLIDO A.; JOÃO, E.; RAMOS, T. B. Exploring experts' views and perspectives on the enhancement of strategic environmental assessment in European small islands.

Environmental Impact Assessment Review, v. 58, p. 25-33, 2016.

REA, L. M.; PARKER, R. A. Designing and Conducting Survey Research: A Comprehensive Guide. fourth ed. Jossey-Bass, San Francisco, 2014.

REGA, C.; BALDIZZONE, G. Public participation in Strategic Environmental Assessment: A practitioners' perspective. Environmental Impact Assessment Review, v. 50, p. 105-115, 2015.

REGA, C.; BONIFAZI, A. Strategic Environmental Assessment and spatial planning in Italy: sustainability, integration and democracy, Journal of Environmental Planning and Management, v. 57, n. 9, p. 1333-1358, 2014.

RETIEF, F. A performance evaluation of Strategic Environmental Assessment processes within the South African context. Environmental Impact Assessment Review, v. 27, n. 1, p. 84-100, 2007. 
RICHARDSON, T.; CASHMORE, M. Power, knowledge and environmental assessment: the World Bank's pursuit of 'good governance'. Journal of Political Power, v. 4, n. 1, p 105-125, 2011.

RITCHIE, J.; LEWIS, J. Qualitative Research Practice: a Guide for Social Science Students and Researchers, Sage Publications, London, Thousand Oaks, New Delhi, 2003.

ROUDGARMI, P. Qualitative research for environmental sciences: A review. Journal of Food, Agriculture \& Environment, v. 9 (3\&4), p. 871-879, 2011.

ROZAS-VÁSQUEZ, D.; FÜRST, C.; GENELETTI, D.; MUÑOZ, F. Multi-actor involvement for integrating ecosystem services in strategic environmental assessment of spatial plans. Environmental Impact Assessment Review, v. 62, 2017.

RUNHAAR, H.; DRIESSEN, P. P. J. What makes strategic environmental assessment successful environmental assessment? The role of context in the contribution of SEA to decision-making. Impact Assessment and Project Appraisal, v. 25, n. 1, 2007.

SADLER, B. Environmental Assessment in a changing world: Evaluating practice to improve performance. Internacional Study of the Effectiveness of Environmental Assessment. IAIA e Canadian Environmental Assessment Agency, 1996.

SANCHEZ, L. E.; SILVA-SÁNCHEZ, S. S. Tiering strategic environmental assessment and project environmental impact assessment in highway planning in São Paulo, Brazil.

Environmental Impact Assessment Review, v. 28, n. 7, p. 515-522, 2008.

SÁNCHEZ-TRIANA, E.; ENRIQUEZ, S. Using policy-based strategic environmental assessments in water supply and sanitation sector reforms: the cases of Argentina and Colombia. Impact Assessment and Project Appraisal, v. 25, n. 3, p. 175-187, 2007.

SCHOLZ, J. T.; WANG, C. L. Cooptation or transformation? Local policy networks and federal regulatory enforcement. American Journal of Political Science, v. 50, p. 81-97, 2006.

SCOLOZZI, R.; MORRI, E., SANTOLINI, R. Delphi-based change assessment in ecosystem service values to support strategic spatial planning in Italian landscapes. Ecological Indicators, v. 21, p. 134-144, 2012.

SEIDMAN, I. Interviewing as Qualitative Research: A Guide for Researchers in Education and the Social Sciences, 3rd ed., Teachers College Press, New York, 2006.

SHEPHERD, A.; ORTOLANO, L. Strategic Environmental Assessment for Sustainable Urban Development. Environmental Impact Assessment Review, v. 16, p. 321-335, 1996.

SILVA, H. V. O.; PIRES, S. H. M.; OBERLING, D. F.; ROVERE, E. L. L. Key recent experiences in the application of SEA in Brazil. Journal of Environmental Assessment Policy and Management, v. 16, n. 2, 2014.

SIMS, L. Taking a learning approach to community-based strategic environmental assessment: results from a Costa Rican case study, Impact Assessment and Project Appraisal, v. 30, n. 4, p. 242-252, 2012.

SINCLAIR, A. J.; SIMS, L.; SPALING, H. Community-based approaches to strategic environmental assessment: Lessons from Costa Rica. Environmental Impact Assessment Review, v. 29, p. 147-156, 2009.

SLUNGE, D.; LOAYZA, F. Greening growth through strategic environmental assessment of sector reforms. Public Administration and Development, v. 32, p. 245-261, 2012. 
SÖDERMAN, T.; SAARELA, S. Biodiversity in strategic environmental assessment (SEA) of municipal spatial plans in Finland, Impact Assessment and Project Appraisal, v. 28, p. 117-133, 2010.

SOUZA, E. M. Metodologias e analíticas qualitativas em pesquisa organizacional: uma abordagem teórico-conceitual. Vitória: EDUFES, 2014.

STOEGLEHNER, G.; BROWN, A. L.; KØRNØV, L. B. SEA and planning: 'ownership' of strategic environmental assessment by the planners is the key to its effectiveness, Impact Assessment and Project Appraisal, v. 27, n. 2, p. 111-120, 2009.

TAO, T.; TAN, Z.; HE, X. Integrating environment into land-use planning through strategic environmental assessment in China: Towards legal frameworks and operational procedures, Environmental Impact Assessment Review, v. 27, p. 243-265, 2007.

TEIXEIRA, I. M. V. O uso da Avaliação Ambiental Estratégica no planejamento da oferta de blocos para exploração e produção de petróleo e gás natural no Brasil: uma proposta. Tese (Doutorado) - Universidade Federal de Rio de Janeiro, COPPE, Rio de Janeiro, 2008. 308 p.

TETLOW, M. F.; HANUSCH, M. Strategic environmental assessment: the state of the art. Impact Assessment and Project Appraisal, v. 30, n.1, p. 15-24, 2012.

THERIVEL, R. Strategic Environmental Assessment in action. London: Earthscan, 2004.

THERIVEL, R.; MINAS, P. Measuring SEA effectiveness: ensuring effective sustainability appraisal. Impact Assessment Project Appraisal, v. 20, n. 2, p. 81-91, 2002.

THERIVEL, R.; WALSH, F. The strategic environmental assessment directive in the UK: 1 year onwards. Environmental Impact Assessment Review, v. 26, p. 663-675, 2006.

THISSEN R. Perspectives on strategic environmental assessment. New York, NY: Lewis. Chapter 8, Criteria for evaluation of SEA; p. 113-29. 2000.

TORGESON, C. Systematic Reviews. Continuum, 2003.

TSHIBANGU, G., M.; MONTAÑO, M. Energy related Strategic Environmental Assessment applied by Multilateral Development Agencies - An analysis based on good practice criteria. Environmental Impact Assessment Review, v. 61, p. 27-37, 2016.

UNALAN, D., COWELL, R. J., Europeanization, Strategic Environmental Assessment and the Impacts on Environmental Governance. Environmental Policy and Governance, v. 19, p. 3243, 2009.

United Nations Economic Commission for Europe (UNECE). Protocol on strategic environmental assessment to the convention on environmental impact assessment in a transboundary context. Geneva: UNECE, 2003.

VAN BUUREN, V. A.; NOOTEBOOM, S. Evaluating strategic environmental assessment in the Netherlands: content, process and procedure as indissoluble criteria for effectiveness. Impact Assessment and Project Appraisal. v. 27, n. 2, p. 145-54, 2009.

VANCLAY, F.; BAINES, J. T.; TAYLOR, C. N. Principles for ethical research involving humans: ethical professional practice in impact assessment Part I. Impact Assessment and Project Appraisal, n. 31, p. 243-253. 2013.

VERHEEM, R. A. A.; TONK, J. A. M. N. Strategic environmental assessment: one concept, multiple forms. Impact Assessment and Project Appraisal, v. 18, n. 3, p. 177-182, 2000. 
VICTOR, D.; AGAMUTHU, P. Policy trends of strategic environmental assessment in Asia, Environmental science \& policy. v. 41, p. 63 - 76, 2014.

WALKER, H. A.; SINCLAIR, J.; SPALING, H. Public participation in and learning through SEA in Kenya, Environmental Impact Assessment Review, v. 45, p. 1-9, 2014.

WENDE, W.; BOND, A.; BOBYLEV, N.; STRATMANN, L. Climate change mitigation and adaptation in strategic environmental assessment. Environmental Impact Assessment Review, v. 32, p. 88-93, 2012.

WORLD BANK. Rapid Strategic Environmental Assessment of Coffee Sector Reform in Burundi. Washington, DC, 2011. Available at: https://openknowledge.worldbank.org/handle/10986/12593

WRIGHT, J.; PARRY, J.; SCULLY, E. Institutionalizing policy-level health impact assessment in Europe: is coupling health impact assessment with strategic environmental assessment the next step forward? Bulletin of the World Health Organization, v. 83, n. 6, 2005.

YIN, R. K. Qualitative Research from Start to Finish, The Guilford Press, New York, 2009. 


\section{Annex 1}

Strategic Environmental Assessment conducted in Brazil (follows)

\begin{tabular}{|c|c|c|c|c|c|c|c|c|c|}
\hline & SEA & Year & Sector & $\begin{array}{l}\text { Sub- } \\
\text { sector }\end{array}$ & Scoping & $\begin{array}{l}\text { Funding } \\
\text { institution }\end{array}$ & $\begin{array}{l}\text { Proponent of } \\
\text { PPP }\end{array}$ & $\begin{array}{c}\text { SEA } \\
\text { consultancies }\end{array}$ & Link \\
\hline 1 & $\begin{array}{l}\text { SEA of Brazil Bolivia } \\
\text { pipeline }\end{array}$ & 1997 & Energy & $\begin{array}{l}\text { Oil and } \\
\text { gas }\end{array}$ & Federal & WB and IADB & $\begin{array}{l}\text { Government of } \\
\text { Bolivia and } \\
\text { Brazil }\end{array}$ & $\begin{array}{c}\text { Prime } \\
\text { Engenharia }\end{array}$ & $\begin{array}{l}\underline{\text { http://documents.worldbank. }} \\
\underline{\text { org/curated/en/65923146876 }} \\
\underline{9837877 / \text { pdf/multi-page.pdf }}\end{array}$ \\
\hline 2 & $\begin{array}{l}\text { Regional environmental } \\
\text { assessment of water } \\
\text { resources management and } \\
\text { integration project }\end{array}$ & 2000 & Energy & $\begin{array}{l}\text { Water } \\
\text { resources }\end{array}$ & Ceará State & WB & $\begin{array}{c}\text { Water } \\
\text { resources } \\
\text { secretariat - } \\
\text { Ceará state }\end{array}$ & $\begin{array}{l}\text { Ceará Insitute of } \\
\text { Natural Science } \\
\text { and independent } \\
\text { Consultants }\end{array}$ & $\begin{array}{l}\underline{\text { http://documents.worldbank. }} \\
\underline{\text { org/curated/en/41058146877 }} \\
\underline{\text { 0492965/text/multi-page.txt }}\end{array}$ \\
\hline 3 & SEA of Chopim river basin & 2002 & Energy & $\begin{array}{l}\text { Hydroele } \\
\text { ctricity }\end{array}$ & Paraná State & - & - & $\begin{array}{l}\text { Environmental } \\
\text { Solutions - } \\
\text { Soluções em } \\
\text { Meio Ambiente } \\
\text { (SOMA) }\end{array}$ & $\begin{array}{l}\frac{\text { http://www.iap.pr.gov.br/mo }}{\text { dules/conteudo/conteudo.php }} \\
\underline{\text { ?conteudo }=772}\end{array}$ \\
\hline 4 & SEA of Areia river & 2002 & Energy & $\begin{array}{l}\text { Hydroele } \\
\text { ctricity }\end{array}$ & Paraná State & - & - & SOMA & Unavailable \\
\hline 5 & $\begin{array}{l}\text { SEA of IADB II, first } \\
\text { phase, Curitiba }\end{array}$ & 2002 & Transport & - & Curitiba City & $\mathrm{IADB}$ & Curitiba City & $\begin{array}{l}\text { Universidade } \\
\text { Livre do Meio } \\
\text { Ambiente }\end{array}$ & $\begin{array}{l}\text { http://www.pt- } \\
\text { pr.org.br/pt_pag/temas.html }\end{array}$ \\
\hline 6 & $\begin{array}{l}\text { SEA of the Multiannual } \\
\text { Federal Plan }\end{array}$ & 2002 & Planning & - & Federal & - & $\begin{array}{l}\text { Planning } \\
\text { ministry }\end{array}$ & - & Unavailable \\
\hline 7 & $\begin{array}{l}\text { SEA of the Indicative Plan } \\
2003-2012\end{array}$ & 2002 & Energy & - & Federal & - & $\begin{array}{l}\text { Eletrobrás / } \\
\text { Cepel }\end{array}$ & $\begin{array}{l}\text { Eletrobrás and } \\
\text { several } \\
\text { consultants }\end{array}$ & Unavailable \\
\hline
\end{tabular}




\begin{tabular}{|c|c|c|c|c|c|c|c|c|c|}
\hline & SEA & Year & Sector & $\begin{array}{l}\text { Sub- } \\
\text { sector }\end{array}$ & Scoping & $\begin{array}{c}\text { Funding } \\
\text { institution }\end{array}$ & $\begin{array}{l}\text { Proponent of } \\
\text { PPP }\end{array}$ & $\begin{array}{c}\text { SEA } \\
\text { consultancies }\end{array}$ & Link \\
\hline 8 & $\begin{array}{l}\text { SEA of Development Plans } \\
\text { of Oil and Natural Gas } \\
\text { Exploration, Production, } \\
\text { Transportation and Use in } \\
\text { the Southern Bahia Coast } \\
\text { (Camamu-Almada Basin) }\end{array}$ & 2003 & Energy & $\begin{array}{l}\text { Oil and } \\
\text { gas }\end{array}$ & Bahia State & $\begin{array}{c}\text { Private } \\
\text { initiative }\end{array}$ & $\begin{array}{c}\text { El Paso, } \\
\text { Petrobras S.A, } \\
\text { Queiroz } \\
\text { Galvão } \\
\text { Perfurações } \\
\text { S.A., Ipiranga } \\
\text { Petróleo do } \\
\text { Brasil S.A. and } \\
\text { Petroserv }\end{array}$ & $\begin{array}{l}\text { Interdisciplinary } \\
\text { environment } \\
\text { laboratory } \\
\text { (LIMA) - } \\
\text { Federal } \\
\text { University of } \\
\text { Rio de Janeiro }\end{array}$ & $\begin{array}{l}\frac{\mathrm{http}: / / \text { www.lima.coppe.ufrj.b }}{\text { r/pages/pagina.php?id=projet }} \\
\underline{\text { os/ipga/10 }}\end{array}$ \\
\hline 9 & $\begin{array}{l}\text { SEA of the National Axis } \\
\text { Portfolio - Ministry of } \\
\text { Planning }\end{array}$ & 2003 & Multisector & - & Federal & - & $\begin{array}{l}\text { Planning } \\
\text { ministry }\end{array}$ & - & Unavailable \\
\hline 10 & $\begin{array}{l}\text { SEA of the São Paulo } \\
\text { Metropolitan Ring Road } \\
\text { Program }\end{array}$ & 2004 & Transport & Highway & $\begin{array}{l}\text { Sao Paulo } \\
\text { State }\end{array}$ & - & $\begin{array}{c}\text { Sao Paulo state } \\
\text { - Transport } \\
\text { department }\end{array}$ & $\begin{array}{l}\text { Foundation } \\
\text { School of } \\
\text { Sociology and } \\
\text { politics of Sao } \\
\text { Paulo (FESPSP) }\end{array}$ & Unavailable \\
\hline 11 & $\begin{array}{l}\text { SEA of the Igarapés de } \\
\text { Manaus Social and } \\
\text { Environmental Program - } \\
\text { PROSAMIM }\end{array}$ & 2004 & Multisector & - & $\begin{array}{l}\text { Amazonas } \\
\text { State }\end{array}$ & IADB & $\begin{array}{l}\text { Government of } \\
\text { Amazonas } \\
\text { state }\end{array}$ & $\begin{array}{l}\text { CONCREMAT e } \\
\text { Federal } \\
\text { University of } \\
\text { Amazonas }\end{array}$ & $\begin{array}{l}\text { http://www.iadb.org/en/proje } \\
\text { cts/project-description- } \\
\text { title,1303.html?id=BR- } \\
\underline{\text { L1297\#doc }}\end{array}$ \\
\hline 12 & $\begin{array}{l}\text { PRODETUR Sul } \\
\text { Programmatic } \\
\text { Environmental Assessment }\end{array}$ & 2004 & Tourism & - & Federal & IADB & $\begin{array}{l}\text { Tourism } \\
\text { Department }\end{array}$ & $\begin{array}{l}\text { Deméter } \\
\text { engineering }\end{array}$ & Unavailable \\
\hline 13 & $\begin{array}{l}\text { Urban Consolidation of } \\
\text { Paulínia }\end{array}$ & 2004 & $\begin{array}{c}\text { Urban } \\
\text { development } \\
\text { and housing }\end{array}$ & - & Metropolitan & IADB & - & - & $\begin{array}{l}\text { http://bidcomunidades.iadb.o } \\
\text { rg/en/projects/project- } \\
\text { description- } \\
\text { title,1303.html?id=BR-T1020 }\end{array}$ \\
\hline
\end{tabular}




\begin{tabular}{|c|c|c|c|c|c|c|c|c|c|}
\hline & SEA & Year & Sector & $\begin{array}{l}\text { Sub- } \\
\text { sector }\end{array}$ & Scoping & $\begin{array}{l}\text { Funding } \\
\text { institution }\end{array}$ & $\begin{array}{l}\text { Proponent of } \\
\text { PPP }\end{array}$ & $\begin{array}{c}\text { SEA } \\
\text { consultancies }\end{array}$ & Link \\
\hline 14 & $\begin{array}{l}\text { SEA of the Alto Paraguay } \\
\text { Basin }\end{array}$ & 2005 & Multisector & - & $\begin{array}{l}\text { Paraguay and } \\
\text { West Center } \\
\text { of Brazil }\end{array}$ & - & $\begin{array}{l}\text { Environmental } \\
\text { ministry }\end{array}$ & $\begin{array}{l}\text { University of the } \\
\text { state of Mato } \\
\text { Grosso } \\
\text { (UNEMAT) and } \\
\text { University of the } \\
\text { state of Mato } \\
\text { Grosso do Sul } \\
\text { (UEMS) }\end{array}$ & Unavailable \\
\hline 15 & $\begin{array}{l}\text { SEA of the Madeira River } \\
\text { Complex }\end{array}$ & 2005 & Energy & $\begin{array}{l}\text { Hydroele } \\
\text { ctricity }\end{array}$ & Federal & $\begin{array}{l}\text { Group of } \\
\text { funding } \\
\text { institutions }\end{array}$ & $\begin{array}{l}\text { Eletrobrás and } \\
\text { Furnas }\end{array}$ & $\begin{array}{l}\text { Arcadis- } \\
\text { Tetraplan }\end{array}$ & $\underline{\underline{\mathrm{https}: / / \mathrm{www} \cdot \text { sendspace.com/f }}}$ \\
\hline 16 & $\begin{array}{l}\text { SEA of the Sao Paulo State } \\
\text { Highway Recovery } \\
\text { Program }\end{array}$ & 2005 & Transport & Highway & $\begin{array}{l}\text { Sao Paulo } \\
\text { State }\end{array}$ & IADB & Sao Paulo state & $\begin{array}{l}\text { Road } \\
\text { Department } \\
\text { (DER) }\end{array}$ & Unavailable \\
\hline 17 & $\begin{array}{l}\text { SEA of the Accessibility } \\
\text { Program for Small } \\
\text { Municipalities with Low } \\
\text { Human Development Index } \\
\text { - PROACESSO }\end{array}$ & 2005 & Transport & - & $\begin{array}{l}\text { Minas Gerais } \\
\text { State }\end{array}$ & IADB & $\begin{array}{l}\text { Minas Gerais } \\
\text { state - } \\
\text { trasnsport } \\
\text { department and } \\
\text { IADB }\end{array}$ & EPIA Ambiental & $\begin{array}{l}\text { http://www.iadb.org/en/proje } \\
\text { cts/project-description- } \\
\text { title,1303.html?id=BR-L1027 }\end{array}$ \\
\hline 18 & $\begin{array}{l}\text { SEA of Rural } \\
\text { Electrification Program of } \\
\text { the Northwest of Minas } \\
\text { Gerais }\end{array}$ & 2005 & Energy & - & $\begin{array}{l}\text { Minas Gerais } \\
\text { State }\end{array}$ & IADB & $\begin{array}{l}\text { Minas Gerais } \\
\text { state - } \\
\text { department of } \\
\text { economic } \\
\text { development }\end{array}$ & Public sector & $\begin{array}{l}\text { http://www.iadb.org/en/proje } \\
\text { cts/project-description- } \\
\text { title,1303.html?id=BR-L1028 }\end{array}$ \\
\hline 19 & $\begin{array}{l}\text { SEA of the semi-arid } \\
\text { Sustainable Development } \\
\text { Program of Sergipe }\end{array}$ & 2005 & Planning & - & $\begin{array}{l}\text { North East of } \\
\text { Brazil }\end{array}$ & IADB & Sergipe state & $\begin{array}{l}\text { Foundation for } \\
\text { the promotion of } \\
\text { technology and } \\
\text { science }\end{array}$ & $\begin{array}{l}\frac{\text { http://idbdocs.iadb.org/wsdoc }}{\text { s/getdocument.aspx?docnum }} \\
=595908\end{array}$ \\
\hline
\end{tabular}




\begin{tabular}{|c|c|c|c|c|c|c|c|c|c|}
\hline & SEA & Year & Sector & $\begin{array}{l}\text { Sub- } \\
\text { sector }\end{array}$ & Scoping & $\begin{array}{l}\text { Funding } \\
\text { institution }\end{array}$ & $\begin{array}{l}\text { Proponent of } \\
\text { PPP }\end{array}$ & $\begin{array}{c}\text { SEA } \\
\text { consultancies }\end{array}$ & Link \\
\hline 20 & $\begin{array}{l}\text { SEA of the Industrial } \\
\text { Complex - Pécem-CIPP } \\
\text { Port and Area of Influence }\end{array}$ & 2006 & Multisector & - & Ceará State & - & $\begin{array}{l}\text { Ceará state - } \\
\text { department of } \\
\text { infrastructure }\end{array}$ & $\begin{array}{l}\text { Technical- } \\
\text { scientific } \\
\text { association } \\
\text { engineer Paulo } \\
\text { de Frontin }\end{array}$ & Não disponível online \\
\hline 21 & $\begin{array}{l}\text { SEA of the Urban } \\
\text { Environmental Quality } \\
\text { Improvement Program of } \\
\text { Amapá }\end{array}$ & 2006 & Sanitation & - & Amapá State & IADB & Amapá state & Amapá state & $\begin{array}{l}\text { http://idbdocs.iadb.org/wsdoc } \\
\text { s/getdocument.aspx?docnum } \\
=\underline{=724751}\end{array}$ \\
\hline 22 & $\begin{array}{l}\text { SEA of the North Coast } \\
\text { Sustainable Tourism } \\
\text { Integrated Development } \\
\text { Plan }\end{array}$ & 2007 & Tourism & - & Federal & IADB & $\begin{array}{l}\text { Turismo } \\
\text { ministry }\end{array}$ & LIMA & $\begin{array}{l}\text { http://www.lima.coppe.ufrj.b } \\
\text { r/pages/pagina.php?id=projet } \\
\text { os/ipga/06 }\end{array}$ \\
\hline 23 & $\begin{array}{l}\text { SEA of the Road Program } \\
\text { of Minas Gerais }\end{array}$ & 2007 & Transport & Highway & $\begin{array}{l}\text { Minas Gerais } \\
\text { State }\end{array}$ & - & $\begin{array}{l}\text { Minas Gerais } \\
\text { state - } \\
\text { department of } \\
\text { transport }\end{array}$ & $\begin{array}{l}\text { Engineering and } \\
\text { economics } \\
\text { consulting (CSL) }\end{array}$ & Não disponível online \\
\hline 24 & $\begin{array}{l}\text { SEA of the Rio Verde Sub- } \\
\text { basin }\end{array}$ & 2007 & Energy & $\begin{array}{l}\text { Hydroele } \\
\text { ctricity }\end{array}$ & $\begin{array}{l}\text { Mato Grosso } \\
\text { do Sul State }\end{array}$ & - & ELETROSUL & SOMA & Não disponível online \\
\hline 25 & $\begin{array}{l}\text { SEA of the Hydroelectric } \\
\text { Generation Program in } \\
\text { Minas Gerais - PGHMG }\end{array}$ & 2007 & Energy & $\begin{array}{l}\text { Hydroele } \\
\text { ctricity }\end{array}$ & $\begin{array}{l}\text { Mato Grosso } \\
\text { do Sul State }\end{array}$ & - & $\begin{array}{c}\text { Minas Gerais } \\
\text { state - } \\
\text { Environemen- } \\
\text { tal and } \\
\text { sustainable } \\
\text { department }\end{array}$ & Arcadis-Logos & Não disponível online \\
\hline 26 & $\begin{array}{l}\text { SEA of the GDF / IADB } \\
\text { Integrated Brasilia Program }\end{array}$ & 2007 & Transport & - & $\begin{array}{c}\text { Federal } \\
\text { District State }\end{array}$ & IADB & $\begin{array}{l}\text { Transporte } \\
\text { department }\end{array}$ & Altran TCBR & Não disponível online \\
\hline
\end{tabular}




\begin{tabular}{|c|c|c|c|c|c|c|c|c|c|}
\hline & SEA & Year & Sector & $\begin{array}{l}\text { Sub- } \\
\text { sector }\end{array}$ & Scoping & $\begin{array}{c}\text { Funding } \\
\text { institution }\end{array}$ & $\begin{array}{c}\text { Proponent of } \\
\text { PPP }\end{array}$ & $\begin{array}{c}\text { SEA } \\
\text { consultancies }\end{array}$ & Link \\
\hline 27 & $\begin{array}{l}\text { SEA of the Northeast } \\
\text { Tourism Development } \\
\text { Program (PRODETUR NE) }\end{array}$ & 2007 & Tourism & - & North East & IADB & $\begin{array}{l}\text { Tourism } \\
\text { ministry }\end{array}$ & LIMA & Não disponível online \\
\hline 28 & $\begin{array}{l}\text { Integrated Environmental } \\
\text { Assessment of } \\
\text { hydroelectric facilities in } \\
\text { the Tocantins River Basin }\end{array}$ & 2007 & Energy & $\begin{array}{l}\text { Hydroele } \\
\text { ctricity }\end{array}$ & $\begin{array}{l}\text { Tocantins } \\
\text { river basin }\end{array}$ & IADB & $\begin{array}{l}\text { Water National } \\
\text { Agency }\end{array}$ & $\begin{array}{l}\text { Arcadis- } \\
\text { Tetraplan }\end{array}$ & $\begin{array}{l}\frac{\mathrm{http}: / / \text { www.epe.gov.br/Meio }}{\text { Ambiente/Paginas/AAI/Meio }} \\
\text { Ambiente_4.aspx?CategoriaI } \\
\mathrm{D}=101\end{array}$ \\
\hline 29 & $\begin{array}{l}\text { Integrated Environmental } \\
\text { Assessment of } \\
\text { hydroelectric facilities in } \\
\text { the Rio Doce Basin }\end{array}$ & 2007 & Energy & $\begin{array}{l}\text { Hydroele } \\
\text { ctricity }\end{array}$ & $\begin{array}{l}\text { South East of } \\
\text { Brazil }\end{array}$ & - & $\begin{array}{l}\text { Energy } \\
\text { research } \\
\text { company }\end{array}$ & - & $\begin{array}{l}\text { http://www.epe.gov.br/Meio } \\
\text { Ambiente/Paginas/AAI/Meio } \\
\text { Ambiente 7.aspx?CategoriaI } \\
\underline{D=101}\end{array}$ \\
\hline 30 & $\begin{array}{l}\text { Integrated Environmental } \\
\text { Assessment of } \\
\text { hydroelectric facilities in } \\
\text { the Paranaíba River Basin }\end{array}$ & 2007 & Energy & $\begin{array}{l}\text { Hydroele } \\
\text { ctricity }\end{array}$ & $\begin{array}{l}\text { Paranaíba } \\
\text { river basin }\end{array}$ & - & $\begin{array}{l}\text { Energy } \\
\text { research } \\
\text { company }\end{array}$ & $\begin{array}{c}\text { Consortium } \\
\text { CNEC } \\
\text { Engenharia S.A / } \\
\text { Technical } \\
\text { projects } \\
\text { (PROJETEC) }\end{array}$ & $\begin{array}{l}\text { http://www.epe.gov.br/Meio } \\
\text { Ambiente/Paginas/AAI/Meio } \\
\underline{\text { Ambiente_3.aspx?CategoriaI }} \\
\underline{D=101}\end{array}$ \\
\hline 31 & $\begin{array}{l}\text { Integrated Environmental } \\
\text { Assessment of } \\
\text { Hydroelectric facilities in } \\
\text { the Paraíba do Sul River } \\
\text { Basin }\end{array}$ & 2007 & Energy & $\begin{array}{l}\text { Hydroele } \\
\text { ctricity }\end{array}$ & $\begin{array}{l}\text { South East of } \\
\text { Brazil }\end{array}$ & - & $\begin{array}{l}\text { Energy } \\
\text { research } \\
\text { company }\end{array}$ & SondoTécnica & $\begin{array}{l}\text { http://www.epe.gov.br/Meio } \\
\text { Ambiente/Paginas/AAI/Meio } \\
\text { Ambiente 6.aspx?CategoriaI } \\
\underline{D=101}\end{array}$ \\
\hline 32 & $\begin{array}{l}\text { Integrated Environmental } \\
\text { Assessment of } \\
\text { Hydroelectric facilities in } \\
\text { the Uruguay River Basin }\end{array}$ & 2007 & Energy & $\begin{array}{l}\text { Hydroele } \\
\text { ctricity }\end{array}$ & $\begin{array}{l}\text { Uruguai river } \\
\text { basin }\end{array}$ & - & $\begin{array}{l}\text { Energy } \\
\text { research } \\
\text { company }\end{array}$ & $\begin{array}{l}\text { Consortium } \\
\text { THEMAG / } \\
\text { Andrade \& } \\
\text { Canellas / } \\
\text { Bourscheid }\end{array}$ & $\begin{array}{l}\text { http://www.epe.gov.br/Meio } \\
\text { Ambiente/Paginas/AAI/Meio } \\
\text { Ambiente_2.aspx?CategoriaI } \\
\underline{\mathrm{D}=101}\end{array}$ \\
\hline 33 & $\begin{array}{l}\text { SEA of the Anchieta } \\
\text { Industrial and Services Pole }\end{array}$ & 2008 & Multisector & - & $\begin{array}{l}\text { Espírito } \\
\text { Santo State }\end{array}$ & - & $\begin{array}{l}\text { Espírito Santo } \\
\text { state }\end{array}$ & Futura & Não disponível online \\
\hline
\end{tabular}




\begin{tabular}{|c|c|c|c|c|c|c|c|c|c|}
\hline & SEA & Year & Sector & $\begin{array}{l}\text { Sub- } \\
\text { sector }\end{array}$ & Scoping & $\begin{array}{c}\text { Funding } \\
\text { institution }\end{array}$ & $\begin{array}{l}\text { Proponent of } \\
\text { PPP }\end{array}$ & $\begin{array}{c}\text { SEA } \\
\text { consultancies }\end{array}$ & Link \\
\hline 34 & $\begin{array}{l}\text { SEA of the Expansion } \\
\text { Plans for Eucalyptus and } \\
\text { Biofuels Forestry in the Far } \\
\text { South of Bahia }\end{array}$ & 2008 & Multisector & - & Bahia State & - & $\begin{array}{l}\text { Environementa } \\
1 \text { department }\end{array}$ & LIMA & $\begin{array}{l}\frac{\text { http://www.lima.coppe.ufrj.b }}{\text { r/pages/pagina.php?id=projet }} \\
\underline{\text { os/ipga/24 }}\end{array}$ \\
\hline 35 & $\begin{array}{l}\text { SEA of the Program of } \\
\text { Corumbá Mining-Industrial } \\
\text { Pole Development and } \\
\text { Influences on the Pantanal } \\
\text { Plain }\end{array}$ & 2008 & Multisector & - & $\begin{array}{l}\text { Mato Grosso } \\
\text { do Sul State }\end{array}$ & - & $\begin{array}{l}\text { Group of } \\
\text { private } \\
\text { intitutions }\end{array}$ & LIMA & $\begin{array}{l}\frac{\text { http://www.lima.coppe.ufrj.b }}{\text { r/pages/pagina.php?id=projet }} \\
\underline{\text { os/ipga/03 }}\end{array}$ \\
\hline 36 & $\begin{array}{l}\text { Integrated Environmental } \\
\text { Assessment of the Piquiri } \\
\text { River Basin }\end{array}$ & 2008 & Energy & $\begin{array}{l}\text { Hydroele } \\
\text { ctricity }\end{array}$ & $\begin{array}{l}\text { Piquiri river } \\
\text { basin }\end{array}$ & - & - & $\begin{array}{l}\text { SOMA and } \\
\text { Consortium } \\
\text { Piquiri }\end{array}$ & $\begin{array}{l}\frac{\text { http://www.iap.pr.gov.br/mo }}{\text { dules/conteudo/conteudo.php }} \\
\underline{\text { ?conteudo }=1074}\end{array}$ \\
\hline 37 & $\begin{array}{l}\text { Integrated Environmental } \\
\text { Assessment of the Rio } \\
\text { Grande Basin }\end{array}$ & 2008 & Energy & $\begin{array}{l}\text { Hydroele } \\
\text { ctricity }\end{array}$ & $\begin{array}{l}\text { Grande river } \\
\text { basin }\end{array}$ & - & - & - & Não disponível online \\
\hline 38 & $\begin{array}{l}\text { SEA of the Açu Industrial } \\
\text { and Port Complex }\end{array}$ & 2009 & Multisector & - & $\begin{array}{c}\text { Rio de } \\
\text { Janeiro Sate }\end{array}$ & - & $\begin{array}{l}\text { LLX and } \\
\text { LIMA }\end{array}$ & Arcadis-Logos & $\begin{array}{l}\text { http://p- } \\
\text { web01.mp.rj.gov.br/Arquivos } \\
\text { /RAP/AAEAcu.pdf }\end{array}$ \\
\hline 39 & $\begin{array}{l}\text { SEA of Plangas, GNL and } \\
\text { COMPERJ developments } \\
\text { in the region around } \\
\text { Guanabara Bay }\end{array}$ & 2009 & Energy & $\begin{array}{l}\text { Oil and } \\
\text { gas }\end{array}$ & $\begin{array}{c}\text { Rio de } \\
\text { Janeiro Sate }\end{array}$ & - & Petrobrás & LIMA & $\begin{array}{l}\frac{\text { http://www.lima.coppe.ufrj.b }}{\text { r/pages/pagina.php?id=projet }} \\
\underline{\text { os/ipga/02 }}\end{array}$ \\
\hline 40 & $\begin{array}{l}\text { SEA of the Turvo River } \\
\text { Basin }\end{array}$ & 2009 & Energy & $\begin{array}{l}\text { Hydroele } \\
\text { ctricity }\end{array}$ & $\begin{array}{l}\text { Turvo river } \\
\text { basin }\end{array}$ & - & Paraná state & $\begin{array}{l}\text { A. Müller } \\
\text { environmental } \\
\text { consulting }\end{array}$ & $\begin{array}{l}\text { http://www.iap.pr.gov.br/arq } \\
\text { uivos/File/EIA_RIMA/Avali } \\
\text { acao_Ambiental_Estrategica } \\
\text { Rio_Turvo.pdf }\end{array}$ \\
\hline
\end{tabular}




\begin{tabular}{|c|c|c|c|c|c|c|c|c|c|}
\hline & SEA & Year & Sector & $\begin{array}{l}\text { Sub- } \\
\text { sector }\end{array}$ & Scoping & $\begin{array}{l}\text { Funding } \\
\text { institution }\end{array}$ & $\begin{array}{l}\text { Proponent of } \\
\text { PPP }\end{array}$ & $\begin{array}{c}\text { SEA } \\
\text { consultancies }\end{array}$ & Link \\
\hline 41 & $\begin{array}{l}\text { Integrated Environmental } \\
\text { Assessment of the } \\
\text { Hydroelectric facilities in } \\
\text { the Xingu River Basin }\end{array}$ & 2009 & Energy & $\begin{array}{l}\text { Hydroele } \\
\text { ctricity }\end{array}$ & $\begin{array}{l}\text { Xingu river } \\
\text { basin }\end{array}$ & - & $\begin{array}{c}\text { ELETROBRÁ } \\
\mathrm{S}\end{array}$ & $\begin{array}{l}\text { Arcadis- } \\
\text { Tetraplan }\end{array}$ & 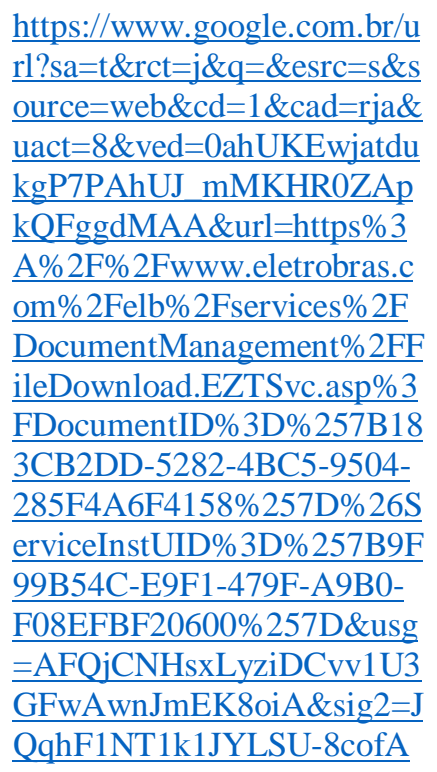 \\
\hline 42 & $\begin{array}{l}\text { Integrated Environmental } \\
\text { Assessment of the Teles } \\
\text { Pires River Basin }\end{array}$ & 2009 & Energy & $\begin{array}{c}\text { Hydroele } \\
\text { ctricity }\end{array}$ & $\begin{array}{l}\text { Teles Pires } \\
\text { river basin }\end{array}$ & - & $\begin{array}{l}\text { Energy } \\
\text { research } \\
\text { company }\end{array}$ & $\begin{array}{l}\text { Consortium } \\
\text { Leme and } \\
\text { Concremat }\end{array}$ & $\begin{array}{l}\text { http://www.epe.gov.br/Meio } \\
\text { Ambiente/Paginas/AAI/Bacia } \\
\text { doRioTelesPires.aspx?Categ } \\
\text { oriaID=101 }\end{array}$ \\
\hline 43 & $\begin{array}{l}\text { SEA of the Mata Branca } \\
\text { Project - Caatinga Biome }\end{array}$ & 2010 & Multisector & - & $\begin{array}{l}\text { Caatinga } \\
\text { biome }\end{array}$ & WB & Ceará state & $\begin{array}{l}\text { University } \\
\text { professors }\end{array}$ & Não disponível online \\
\hline 44 & $\begin{array}{l}\text { SEA of the Multimodal } \\
\text { Transport and Mining- } \\
\text { Industrial Development } \\
\text { Program of the Cacaueira } \\
\text { Region - Porto Sul } \\
\text { Complex }\end{array}$ & 2010 & Multisector & - & Bahia State & - & $\begin{array}{c}\text { Environmental } \\
\text { departament }\end{array}$ & LIMA & $\begin{array}{l}\text { http://www.inema.ba.gov.br/ } \\
\text { estudos- } \\
\text { ambientais/avaliacao- } \\
\text { ambiental/porto-sul/\# }\end{array}$ \\
\hline
\end{tabular}




\begin{tabular}{|c|c|c|c|c|c|c|c|c|c|}
\hline & SEA & Year & Sector & $\begin{array}{l}\text { Sub- } \\
\text { sector }\end{array}$ & Scoping & $\begin{array}{c}\text { Funding } \\
\text { institution }\end{array}$ & $\begin{array}{l}\text { Proponent of } \\
\text { PPP }\end{array}$ & $\begin{array}{c}\text { SEA } \\
\text { consultancies }\end{array}$ & Link \\
\hline 45 & $\begin{array}{l}\text { SEA of the Metropolitan } \\
\text { Arc Master Plan }\end{array}$ & 2010 & Transport & - & $\begin{array}{c}\text { Rio de } \\
\text { Janeiro Sate }\end{array}$ & IADB & $\begin{array}{l}\text { Rio de Janeiro } \\
\text { state }\end{array}$ & $\begin{array}{l}\text { TECNOSOLO / } \\
\text { Arcadis-Logos }\end{array}$ & Não disponível online \\
\hline 46 & $\begin{array}{l}\text { Strategic Environmental } \\
\text { Planning of the Port, } \\
\text { Industrial, Naval and } \\
\text { Offshore Dimension in São } \\
\text { Paulo Coast - PINO }\end{array}$ & 2010 & Multisector & - & $\begin{array}{l}\text { Sao Paulo } \\
\text { State }\end{array}$ & - & Sao Paulo state & Arcadis-Logos & $\begin{array}{l}\frac{\text { http://www.energia.sp.gov.br }}{\text { la2sitebox/arquivos/documen }} \\
\text { tos/234.pdf }\end{array}$ \\
\hline 47 & $\begin{array}{l}\text { Integrated Environmental } \\
\text { Assessment of the Tibagi } \\
\text { River Basin }\end{array}$ & 2010 & Energy & $\begin{array}{l}\text { Hydroele } \\
\text { ctricity }\end{array}$ & Paraná Sate & - & $\begin{array}{l}\text { Energy } \\
\text { research } \\
\text { company }\end{array}$ & $\begin{array}{l}\text { Independent } \\
\text { consultants }\end{array}$ & $\begin{array}{l}\text { http://www.epe.gov.br/Meio } \\
\text { Ambiente/Paginas/AAI/Meio } \\
\text { Ambiente_13.aspx?Categoria } \\
\underline{\text { ID }=101}\end{array}$ \\
\hline 48 & $\begin{array}{l}\text { Integrated Environmental } \\
\text { Assessment of the Juruena } \\
\text { River Basin }\end{array}$ & 2010 & Energy & $\begin{array}{l}\text { Hydroele } \\
\text { ctricity }\end{array}$ & $\begin{array}{c}\text { Mato Grosso } \\
\text { state }\end{array}$ & - & $\begin{array}{l}\text { Energy } \\
\text { research } \\
\text { company }\end{array}$ & $\begin{array}{c}\text { CNEC } \\
\text { Engineering }\end{array}$ & $\begin{array}{l}\text { http://www.epe.gov.br/Meio } \\
\text { Ambiente/Paginas/AAI/Bacia } \\
\text { doRioJuruena.aspx?Categori } \\
\underline{\text { aID=101 }}\end{array}$ \\
\hline 49 & $\begin{array}{l}\text { SEA of the Ceará Regional } \\
\text { Urban Development } \\
\text { Program - Acaraú Valley }\end{array}$ & 2010 & $\begin{array}{c}\text { Urban } \\
\text { development }\end{array}$ & - & Ceará state & IADB & Ceará state & $\begin{array}{c}\text { Portuguese } \\
\text { inovation society } \\
(\mathrm{SPI})\end{array}$ & Não disponível online \\
\hline 50 & $\begin{array}{l}\text { SEA of the set of actions } \\
\text { included in the Integrated } \\
\text { Tourism Development Plan } \\
\text { (PDITS) of the Costa das } \\
\text { Dunas, Costa Branca and } \\
\text { Seridó tourist centers }\end{array}$ & 2011 & Tourism & - & $\begin{array}{l}\text { Rio Grande } \\
\text { do Norte } \\
\text { state }\end{array}$ & - & $\begin{array}{l}\text { Rio Grande do } \\
\text { Norte state - } \\
\text { department of } \\
\text { Tourism }\end{array}$ & $\begin{array}{l}\text { Start research } \\
\text { and technical } \\
\text { consultancy }\end{array}$ & Não disponível online \\
\hline 51 & $\begin{array}{l}\text { SEA of the Bioceanic Rail } \\
\text { Corridor - Capricorn Axis }\end{array}$ & 2011 & Transport & Railroad & Federal & - & $\begin{array}{l}\text { Group of } \\
\text { private } \\
\text { initiatives }\end{array}$ & $\begin{array}{c}\text { ERNEST \& } \\
\text { YOUNG / } \\
\text { TRENDS / } \\
\text { ENEFER / } \\
\text { VETEC / EBEI }\end{array}$ & Não disponível online \\
\hline
\end{tabular}




\begin{tabular}{|c|c|c|c|c|c|c|c|c|c|}
\hline & SEA & Year & Sector & $\begin{array}{l}\text { Sub- } \\
\text { sector }\end{array}$ & Scoping & $\begin{array}{c}\text { Funding } \\
\text { institution }\end{array}$ & $\begin{array}{l}\text { Proponent of } \\
\text { PPP }\end{array}$ & $\begin{array}{c}\text { SEA } \\
\text { consultancies }\end{array}$ & Link \\
\hline 52 & $\begin{array}{l}\text { SEA of PRODETUR Rio } \\
\text { de Janeiro - Coastal Polo }\end{array}$ & 2011 & Tourism & - & - & IADB & $\begin{array}{c}\text { Ministry of } \\
\text { Tourism and } \\
\text { Rio de Janeiro } \\
\text { state }\end{array}$ & $\begin{array}{l}\text { Coordination and } \\
\text { management } \\
\text { nucleus }\end{array}$ & $\begin{array}{l}\text { http://www.prodetur.rj.gov.br } \\
\text { lavaliacaoambiental.asp }\end{array}$ \\
\hline 53 & $\begin{array}{l}\text { SEA of PRODETUR Rio } \\
\text { de Janeiro - Polo Serra }\end{array}$ & 2011 & Tourism & - & - & IADB & $\begin{array}{c}\text { Ministry of } \\
\text { Tourism and } \\
\text { Rio de Janeiro } \\
\text { state }\end{array}$ & $\begin{array}{l}\text { Coordination and } \\
\text { management } \\
\text { nucleus }\end{array}$ & $\begin{array}{l}\text { http://www.prodetur.ri.gov.br } \\
\text { lavaliacaoambiental.asp }\end{array}$ \\
\hline 54 & $\begin{array}{l}\text { Integrated Environmental } \\
\text { Assessment of the } \\
\text { Aripuanã River Basin }\end{array}$ & 2011 & Energy & $\begin{array}{l}\text { Hydroele } \\
\text { ctricity }\end{array}$ & $\begin{array}{c}\text { Aripuanã } \\
\text { river basin }\end{array}$ & - & $\begin{array}{l}\text { Energy } \\
\text { research } \\
\text { company }\end{array}$ & $\begin{array}{l}\text { THEMAG } \\
\text { Engineering }\end{array}$ & $\begin{array}{l}\frac{\mathrm{http}: / / \text { www.epe.gov.br/Meio }}{\text { Ambiente/Paginas/AAI/Bacia }} \\
\text { doRioAripuan\%C3\%A3.aspx } \\
\text { ?CategoriaID }=101\end{array}$ \\
\hline 55 & $\begin{array}{l}\text { Integrated Environmental } \\
\text { Assessment of the Jari } \\
\text { River Basin }\end{array}$ & 2011 & Energy & $\begin{array}{l}\text { Hydroele } \\
\text { ctricity }\end{array}$ & $\begin{array}{l}\text { Jari river } \\
\text { basin }\end{array}$ & - & $\begin{array}{l}\text { Energy } \\
\text { research } \\
\text { company }\end{array}$ & $\begin{array}{l}\text { Hydros } \\
\text { Engineering }\end{array}$ & $\begin{array}{l}\text { http://www.epe.gov.br/Meio } \\
\text { Ambiente/Paginas/AAI/Bacia } \\
\text { doRioJari.aspx?CategoriaID }= \\
\underline{101}\end{array}$ \\
\hline 56 & $\begin{array}{l}\text { Integrated Environmental } \\
\text { Assessment of the Araguaia } \\
\text { River Basin }\end{array}$ & 2011 & Energy & $\begin{array}{l}\text { Hydroele } \\
\text { ctricity }\end{array}$ & $\begin{array}{c}\text { Araguaia } \\
\text { river basin }\end{array}$ & - & $\begin{array}{l}\text { Energy } \\
\text { research } \\
\text { company }\end{array}$ & ENGEVIX & $\begin{array}{l}\frac{\mathrm{http}: / / \text { www.epe.gov.br/Meio }}{\text { Ambiente/Paginas/AAI/Bacia }} \\
\text { doRioAraguaia.aspx?Categor } \\
\text { iaID=101 }\end{array}$ \\
\hline 57 & $\begin{array}{l}\text { Integrated Environmental } \\
\text { Assessment of the Rio } \\
\text { Branco River Basin - } \\
\text { Hydroelectric Inventory } \\
\text { Study of the Rio Branco / } \\
\text { RR }\end{array}$ & 2011 & Energy & $\begin{array}{l}\text { Hydroele } \\
\text { ctricity }\end{array}$ & Roraima state & - & $\begin{array}{l}\text { Energy } \\
\text { research } \\
\text { company }\end{array}$ & $\begin{array}{l}\text { Hydros } \\
\text { Engineering }\end{array}$ & $\begin{array}{l}\text { http://www.epe.gov.br/Meio } \\
\text { Ambiente/Paginas/AAI/Bacia } \\
\text { doRioBranco.aspx?Categoria } \\
\underline{\underline{I D}=101}\end{array}$ \\
\hline 58 & Federal Road Transport & 2012 & Transport & - & Federal & WB & - & - & Não disponível online \\
\hline 59 & Energy and Mining TAL & 2012 & Multisector & - & Federal & WB & - & - & Não disponível online \\
\hline
\end{tabular}




\begin{tabular}{|c|c|c|c|c|c|c|c|c|c|}
\hline & SEA & Year & Sector & $\begin{array}{l}\text { Sub- } \\
\text { sector }\end{array}$ & Scoping & $\begin{array}{c}\text { Funding } \\
\text { institution }\end{array}$ & $\begin{array}{l}\text { Proponent of } \\
\text { PPP }\end{array}$ & $\begin{array}{c}\text { SEA } \\
\text { consultancies }\end{array}$ & Link \\
\hline 60 & $\begin{array}{l}\text { Strategic Study of Public } \\
\text { Policies in the Caatinga } \\
\text { Biome Area of the State of } \\
\text { Bahia }\end{array}$ & 2013 & $\begin{array}{l}\text { Natural } \\
\text { resources }\end{array}$ & - & Bahia state & - & $\begin{array}{l}\text { Regional } \\
\text { development } \\
\text { and action } \\
\text { company } \\
\text { (CAR) }\end{array}$ & LIMA & $\begin{array}{l}\text { http://www.lima.coppe.ufrj.b } \\
\text { r/pages/pagina.php?id=projet } \\
\text { os/ipga/34 }\end{array}$ \\
\hline 61 & $\begin{array}{l}\text { SEA of the National } \\
\text { PRODETUR in the State of } \\
\text { Mato Grosso do Sul - Polo } \\
\text { Campo Grande and Region }\end{array}$ & 2014 & Tourism & - & - & IADB & $\begin{array}{l}\text { State of Mato } \\
\text { Grosso do Sul }\end{array}$ & $\begin{array}{l}\text { Deméter } \\
\text { Engineering }\end{array}$ & $\begin{array}{l}\frac{\mathrm{http}: / / \text { www.turismo.gov.br/sit }}{\text { es/default/turismo/DPROD/A }} \\
\text { VALIACAO_AMBIENTAL/ } \\
\text { MS/AAE_POLO CAMPO } \\
\text { GRANDE MS.pdf }\end{array}$ \\
\hline 62 & $\begin{array}{l}\text { SEA of the National } \\
\text { PRODETUR in the State of } \\
\text { Mato Grosso do Sul - Serra } \\
\text { da Bodoquena Tourist } \\
\text { Center }\end{array}$ & 2014 & Tourism & - & $\begin{array}{l}\text { State of Mato } \\
\text { Grosso do } \\
\text { Sul }\end{array}$ & IADB & $\begin{array}{l}\text { State of Mato } \\
\text { Grosso do Sul }\end{array}$ & $\begin{array}{l}\text { Deméter } \\
\text { Engineering }\end{array}$ & $\begin{array}{l}\frac{\mathrm{http}: / / \text { www.turismo.gov.br/sit }}{\text { es/default/turismo/DPROD/A }} \\
\text { VALIACAO_AMBIENTAL/ } \\
\text { MS/AAE_SERRA_DA_BO } \\
\text { DOQUENA_MS.pdf }\end{array}$ \\
\hline 63 & $\begin{array}{l}\text { Integrated Environmental } \\
\text { Assessment of the Tapajós } \\
\text { Basin }\end{array}$ & 2014 & Energy & $\begin{array}{l}\text { Hydroele } \\
\text { ctricity }\end{array}$ & $\begin{array}{l}\text { Tapajós river } \\
\text { basin }\end{array}$ & - & Eletrobrás & Ecology Brazil & $\begin{array}{l}\text { http://www.grupodeestudosta } \\
\text { pajos.com.br/avaliacao- } \\
\text { ambiental-integrada-da- } \\
\text { bacia-do-rio-tapajos-3/ }\end{array}$ \\
\hline 64 & $\begin{array}{l}\text { Social and Environmental } \\
\text { Impact Assessment of the } \\
\text { Transport, Logistics and } \\
\text { Environment Program }\end{array}$ & 2014 & Transport & Highway & $\begin{array}{l}\text { Sao Paulo } \\
\text { state }\end{array}$ & WB & Sao Paulo state & $\begin{array}{c}\text { Prime } \\
\text { Engineering }\end{array}$ & $\begin{array}{l}\frac{\text { http://www.der.sp.gov.br/We }}{\text { bSite/Acessos/MalhaRodovia }} \\
\underline{\text { ria/ImpactoSocial.aspx }}\end{array}$ \\
\hline
\end{tabular}

Strategic Environmental

Revaluation of the

65 Guanabara Bay Coverage

Area and Surrounding

2016 Energy Oil and Rio de

gas Janeiro state

Petrobrás

LIMA

Não disponível online

Region of COMPERJ 


\begin{tabular}{|c|c|c|c|c|c|c|c|c|c|}
\hline & SEA & Year & Sector & $\begin{array}{l}\text { Sub- } \\
\text { sector }\end{array}$ & Scoping & $\begin{array}{c}\text { Funding } \\
\text { institution }\end{array}$ & $\begin{array}{l}\text { Proponent of } \\
\text { PPP }\end{array}$ & $\begin{array}{c}\text { SEA } \\
\text { consultancies }\end{array}$ & Link \\
\hline 66 & $\begin{array}{l}\text { Piauí Inclusive Production } \\
\text { for Sustainable } \\
\text { Development DPL }\end{array}$ & 2016 & - & - & $\begin{array}{c}\text { Regional } \\
\text { development }\end{array}$ & - & - & - & Não disponível online \\
\hline 67 & $\begin{array}{l}\text { Integrated Environmental } \\
\text { Assessment of the Tijuco } \\
\text { River Basin - Minas Gerais }\end{array}$ & - & Energy & $\begin{array}{c}\text { Hydroele } \\
\text { ctricity }\end{array}$ & $\begin{array}{l}\text { Minas Gerais } \\
\text { state }\end{array}$ & - & - & - & Não disponível online \\
\hline
\end{tabular}

\section{Other SEA (identified by participants)}

Strategic planning of

69 federal eco / sustainable $1990 \quad$ Tourism tourism. EMBRATUR

Integrated Environmental

Assessment of the Parnaíba

70 Basin - Parnaíba Basin -

Northeast (Piauí and

Maranhão)

\begin{tabular}{|c|c|c|c|c|}
\hline 71 & $\begin{array}{l}\text { Evaluation of the Iguaçu } \\
\text { River (PR) Aquatic } \\
\text { Ecoregion }\end{array}$ & 2008 & $\begin{array}{l}\text { Water } \\
\text { resources }\end{array}$ & Paraná state \\
\hline 72 & $\begin{array}{l}\text { SEA of the Tocantins- } \\
\text { Araguaia Basin Strategic } \\
\text { Water Resources Plan }\end{array}$ & 2008 & $\begin{array}{c}\text { Water } \\
\text { resources }\end{array}$ & $\begin{array}{l}\text { Tocantins - } \\
\text { Araguaia } \\
\text { rivers basin }\end{array}$ \\
\hline
\end{tabular}




\begin{tabular}{|c|c|c|c|c|c|c|c|c|c|}
\hline & SEA & Year & Sector & $\begin{array}{c}\text { Sub- } \\
\text { sector }\end{array}$ & Scoping & $\begin{array}{l}\text { Funding } \\
\text { institution }\end{array}$ & $\begin{array}{l}\text { Proponent of } \\
\text { PPP }\end{array}$ & $\begin{array}{c}\text { SEA } \\
\text { consultancies }\end{array}$ & Link \\
\hline 73 & $\begin{array}{l}\text { SEA of Ceará's } \\
\text { Environmental Sanitation } \\
\text { Policy }\end{array}$ & 2017 & Sanitation & & Ceará state & WB & & Arcadis & $\begin{array}{l}\text { http://www.institutoagropolo } \\
\text { s.org.br/img/uploads/arquivo } \\
\text { s/jhjkjk_2011201717685157 } \\
\text { 78.pdf }\end{array}$ \\
\hline 74 & $\begin{array}{l}\text { SEA of the naval pole in } \\
\text { the Bay of todos os santos }\end{array}$ & & Transport & & $\begin{array}{l}\text { Todos os } \\
\text { santos bay }\end{array}$ & & & & \\
\hline 75 & $\begin{array}{l}\text { Environmental Assessment } \\
\text { of the Santo Antonio River. } \\
\text { Minas Gerais }\end{array}$ & & $\begin{array}{l}\text { Water } \\
\text { resources }\end{array}$ & & $\begin{array}{l}\text { Minas Gerais } \\
\text { State }\end{array}$ & & & & \\
\hline 76 & $\begin{array}{l}\text { SEA of the Agriculture } \\
\text { development in the state of } \\
\text { Minas Gerais }\end{array}$ & & Agriculture & & $\begin{array}{l}\text { Minas Gerais } \\
\text { State }\end{array}$ & & & & \\
\hline 77 & $\begin{array}{l}\text { Porto Central - Presidente } \\
\text { Kennedy Municipality - } \\
\text { Espírito Santo }\end{array}$ & & Transport & & $\begin{array}{l}\text { Espírito } \\
\text { Santo state }\end{array}$ & & & & \\
\hline
\end{tabular}




\section{Annex 2}

\section{Outcomes}

Reference

1 SEA provokes frame reflection and policy-oriented learning (on various

10,29 aspects including the necessity of SEA): in which stakeholders are invited to reflect upon their policy beliefs and problem definitions and to adjust their frames accordingly.

2 SEA enables the understanding and awareness of $3,7,14,15,18$ environmental/sustainability issues, SEA process and the PPP.

3 SEA enables / increases system learning, knowledge and improvements.

4 SEA provides good experiences on participation in the SEA process.

19,33

5 SEA provides problem-solving skills related to evaluating impacts, creating 14,48 mitigation strategies

6 SEA changes or influences institutional norms or management practices

4,38

7 SEA changes organisation's values (objectives, goals, mission).

\section{5,38}

8 SEA enables changes in attitudes towards environmental issues of persons, 5,48 institutions and other stakeholders / the general public involved in the planning process

9 SEA ensures the knowledge of the rules and expectations

6,7

10 SEA enables critical self and communal awareness

14,33

11 SEA enables the recognition of the usefulness of working together 14,48 Institutions learning to engage differently with communities

12 SEA improves public awareness of the agency or organization as a result of 4,14 SEA application (e.g. transparency and accountability).

13 SEA improves overall awareness of the agency's or organization's actions, PPPs..

14 SEA generates (mutual) learning processes between consultants, public authorities and the general public.

15 SEA validity and credibility are accepted by the stakeholders 10

16 SEA may guarantee that all stakeholder (including public) concerns are taken into account 


\section{Outcomes}

Reference

18 SEA is an opportunity for active participation.

$8,16,17$

19 SEA makes consultation with the communities much more focused in a

$6,25,29,51$ meaningful way.

20 SEA is a vehicle to acquire relevant information.

$1,6,8,13$

21 SEA is a vehicle to communicate information.

$1,6,8,13$

22 SEA ensures a greater ownership of the final PPP by the public.

$7,14,35,46$

23 SEA ensures a better management of (potential) conflicts and/or better 7,10 acceptance of the final outcomes.

24 SEA identifies strategies for enhancement of positive impacts.

$4,9,16$

25 SEA allows definition of opportunities for the area development.

9

26 SEA identifies possible conflicts between the objectives of the PPP 16 document and national (or sectoral) environmental objectives.

27 SEA assesses and manages cumulative effects.

$6,12,19,45$

28 SEA addresses climate change issues.

$11,26,28$

29 SEA provides an opportunity to identify and focus on the main issue.

30 SEA allows identification of the critical aspects to be addressed before the $9,14,35,36$ PPP implementation.

31 SEA incorporates sustainability considerations (e.g. relationships between human-ecological systems; intra- and intergenerational equity; precaution and adaptation; socio-economic concerns) into the PPP development or PPP approval/decision-making process.

\begin{tabular}{lll}
\hline 32 & SEA turns the strategic action more sustainable or environmentally benign. & 3,16 \\
\hline 33 & SEA allows enhancement / improvement of key features of the PPP. & 4,21 \\
\hline 34 & SEA allows enhancement/ improvement of key features of the PPP & 4,9 \\
\hline 35 & SEA expands the scope of the PPP & 4,16 \\
\hline 36 & SEA develops environmental objectives for the PPP that is being assessed. & 16 \\
\hline 37 & SEA modifies the objectives of the PPP. & 4,17 \\
\hline 38 & $\begin{array}{l}\text { SEA ensures compliance of the PPP with the agency's/organization's } \\
\text { mandate, regulations or higher-level policy commitments. } \\
\text { OBS: the departments and agencies responsible for the SEA must share a } \\
\text { similar vision with those other departments and agencies who are either } \\
\text { involved in the SEA or in PPP implementation }\end{array}$ &
\end{tabular}

39 SEA helped realize broader organizational or institutional goals and objectives beyond the scope of the PPP itself. 
40 SEA gives sufficient consideration to viable/possible alternatives, if applicable, to the proposed or existing PPP.

41 SEA produced knowledge enables an integral weighing of options valued as 10,50 relevant by the stakeholders.

42 SEA provides easily accessible information (e.g. baseline data, thresholds, etc.) for use in subsequent PPP processes, monitoring programs or projectbased impact assessment.

\begin{tabular}{|c|c|c|}
\hline 43 & SEA increases access to environmental information. & $14,18,36,55$ \\
\hline 44 & SEA provides a better understanding of the PPP acceptability. & 6,14 \\
\hline 45 & SEA identifies data gaps and baseline conditions. & $6,14,44$ \\
\hline 46 & $\begin{array}{l}\text { SEA participants receives information related to: the PPP; how to reduce } \\
\text { their environment impact; their community and environment }\end{array}$ & $14,36,55$ \\
\hline 47 & $\begin{array}{l}\text { SEA provides regulators with a better understanding of the risks of PPPs, } \\
\text { stakeholder perspectives, and thus more confidence in their decisions. }\end{array}$ & $1,2,6$ \\
\hline 48 & $\begin{array}{l}\text { SEA helps increase the credibility/transparency/accountability of end results } \\
\text { (and the final decision). }\end{array}$ & $1,3,4,7,19$ \\
\hline 49 & $\begin{array}{l}\text { SEA provides clear direction or standards to facilitate implementation of the } \\
\text { PPP, including guidance for post implementation monitoring or evaluation. }\end{array}$ & $4,24,34,43$ \\
\hline 50 & SEA is a way of reducing the loss of time and money. & $14,17,34,43,53$ \\
\hline 51 & SEA guides the PPP planning and design through a gradual process. & 4,9 \\
\hline 52 & $\begin{array}{l}\text { SEA results in more environmentally friendly or sustainable decisions than } \\
\text { would have been the case otherwise. }\end{array}$ & $1,24,34,43,48$ \\
\hline 53 & SEA leads to improve regulatory decisions. & $6,34,37,43,48$ \\
\hline 54 & SEA helps to coordinate current planning and data collection initiatives. & $6,34,37$ \\
\hline 55 & $\begin{array}{l}\text { SEA enables the use of new ideas (e.g. time or cost savings on subsequent } \\
\text { plans or project assessments) in the next rounds of decision-making. }\end{array}$ & 3,4 \\
\hline 56 & $\begin{array}{l}\text { SEA enables the streamlining of assessment procedures for individual } \\
\text { projects. }\end{array}$ & $\begin{array}{l}17,20,22,25,34 \\
35,42,45,50,55 \\
61\end{array}$ \\
\hline 57 & $\begin{array}{l}\text { SEA improves actual environmental or socioeconomic conditions or raises } \\
\text { environmental or socioeconomic standards. }\end{array}$ & $4,14,22,33$ \\
\hline 58 & SEA improves environmental protection. & 17,19 \\
\hline 59 & SEA ensure compensation. & 8 \\
\hline 60 & SEA helps recognize the value of environmental conservation. & $14,38,46$ \\
\hline 61 & $\begin{array}{l}\text { SEA ensures enough freedom to the birth of spontaneous cooperative } \\
\text { behaviors by the enterprises that shall settle into the area assessed and that } \\
\text { could benefit from the integration and synergies with other enterprises (e.g., } \\
\text { reuse of second raw materials, exchange of water and energy flows). }\end{array}$ & 9,52 \\
\hline
\end{tabular}

62 SEA ensures better communication and co-operation of authorities, individuals, other institutions and organisations. 
63 SEA enables trust-building between involved parties.

64 SEA allows identification of cumulative impacts and also those environmental aspects which should be given particular consideration by the

$6,12,14,19,20$ more detailed project level analysis afforded by the EIAs.

65 SEA provides a framework of headroom capacities for individual 20,50 environmental aspects, within which the Master Planners can develop their proposals.

66 SEA includes formulation of a monitoring framework which is not normally covered by an EIA

14,20

67 SEA enables the monitoring of the PPP's environmental effects in relation to what was predicted and / or the identification of unforeseen adverse impacts.

68 SEA assesses transboundary environmental impact.

14,23

69 SEA promotes the selection of relevant information, based on the objectives 14,24 and themes of the SEA itself.

70 SEA identifies and analyzes PPPs related to the evaluated strategic action.

71 SEA promotes institutional integration and stakeholder participation.

72 SEA promotes articulation between environmental issues, economic and social development, public participation and decision making process.

73 SEA helps to put biodiversity in the perspective of social and economic needs and to make values of the parties transparent.

74 SEA builts capacity in the community and national institutions for doing it again.

75 SEA promotes Ecosystem services integration in spatial planning 31, 32

76 SEA provides a methodological approach to analyze various planning components and to put important issues into perspective.

77 SEA identifies pre-implementation actions that are needed for the projects installation

34,35

78 SEA integrates the impact assessment tool with other instruments

40

79 SEA demonstrates industry commitment to environment and society

80 SEA addresses the integration of sustainability criteria as part of the impact evaluation process

$36,45,55$

81 SEA allows for emergent insights and shifts in problem perspectives and objectives over time, with the consent of all those involved

82 The planner can innovate through SEA 47

83 The planner may utilize SEA but only in implementation gaps 47

84 SEA has the potential to screen out many environmentally unfriendly 50,51 projects or guide many projects before irreversible decisions are taken, such as land acquisition, selection of the development proposal and financing commitments 


\begin{tabular}{llc}
\hline \multicolumn{1}{c}{ Outcomes } & Reference \\
\hline 85 & SEA allows an active promotion of tiering & 51 \\
\hline 86 & $\begin{array}{l}\text { SEA allows the integration of the multiple visions of the problem, and } \\
\text { establishment of the consequent communication links towards learning } \\
\text { interaction. }\end{array}$ & 51 \\
\hline 87 & $\begin{array}{l}\text { SEA provides guidance on the communication strategies to enhance the } \\
\text { social relevance of technical and scientific knowledge, creating new attitudes } \\
\text { in face of technical facts. }\end{array}$ & 51 \\
\hline 88 & $\begin{array}{l}\text { SEA has a role in fostering policy coherence and making local authorities } \\
\text { and planners more aware of the whole system of environmental governance } \\
\text { that may affect local decisions }\end{array}$ & $6,8,13,52$ \\
\hline 89 & $\begin{array}{l}\text { SEA plays a central role in delivering the administration's commitment to } \\
\text { environmental justice and sustainable development }\end{array}$ & $4,42,53$ \\
\hline 90 & $\begin{array}{l}\text { SEA document was considered valuable for analyzing future projects in the } \\
\text { region }\end{array}$ & $14,18,36,55$ \\
\hline 91 & $\begin{array}{l}\text { SEA mitiges the potentially negative effects of the plans before these have } \\
\text { been implemented, assuming individual projects will then be implemented } \\
\text { under a sustainability framework }\end{array}$ & 14,60 \\
\hline \begin{tabular}{l} 
SEA promotes social learning for continuous policy improvement \\
\hline
\end{tabular} & $3,14,15,62$ \\
\hline
\end{tabular}

(1) Runhaar and Driessen (2007); (2) Fidler and Noble (2012); (3) Thérivel and Minas (2002); (4) Acharibasam and Noble (2014); (5) Fischer et al. (2009); (6) Noble et al. (2013); (7) Rega and Baldizzone (2015); (8) Walker, Sinclair and Spaling (2013); (9) Conticelli and Tondelli (2013); (10) Buuren and Nooteboom (2010); (11) Crnčević, Marić and Josimović (2011); (12) Bragagnolo, Geneletti and Fischer (2012); (13) Elling (1997); (14) Sims (2012); (15) João and Mclauchlan (2014); (16) Peterson (2004); (17) Unalan and Cowell (2009); (18) Hansen (2011); (19) Tao et al. (2007); (20) Cole and Broderick (2007); (21) Santos and Souza (2011); (22) Jackson and Dixon (2006); (23) Marsden (2011); (24) Pizella and Souza (2013); (25) Esteves and Souza (2014); (26) Larsen and Kørnøv (2013); (27) Söderman and Saarela (2010); (28) Wende et al. (2012); (29) Sinclair and Sims (2009); (30) Liou and Yu (2004); (31) Mascarenhas et al. (2015); (32) Partidario and Gomes (2013); (33) Jha-Thakur et al. (2009); (34) Nooteboom (2000); (35) Hamblin (1999); (36) Polido, João and Ramos (2016); (37) Cun-Kuan, Yong-Sen and Jin-cheng (2004); (38) Slunge and Loayza (2012); (39) Douglas, Carver and Katikireddi (2011); (40) Andrade and Santos (2015); (41) Wright, Parry and Scully (2005); (42) Noble (2004); (43) Hegazy (2015); (44) Hipondoka, Dalal-Clayton and Gils (2016); (45) Noble (2009); (46) Kørnøv and Thissen (2000); (47) Stoeglehner, Brown and Kørnøv (2009); (48) Tetlow and Hanusch (2012); (49) Barker (2006); (50) ALSHUWAIKHAT (2005); (51) Kirchhoff et al. (2011); (52) Rega and Bonifazi (2014); (53) Jackson and Illsley (2006); (54) Kørnøv (2009); (55) Shepherd and Ortolano (1996); (56) Ng and Obbard (2005); (57) Fischer, Matuzzi and Nowacki (2010); (58) Partidário and Coutinho (2011); (59) Therivel and Walsh (2006); (60) Lobos and Partidario (2014); (61) Sánchez and Silva-Sánchez (2008); (62) Sánchez-Triana and Enriquez (2007). 


\section{Annex 3 \\ Questionnaire: Intervening aspects on the influence of SEA on the development of Plans and Programs in Brazil}

This questionnaire is part of the doctoral research entitled "Intervening aspects on the influence of SEA on the development of Plans and Programs in Brazil". The aim is to identify and describe the contextual elements (presence / absence of regulation; ; relations between the agents and institutions involved; type of strategic action; timing for the accomplishment of SEA; among others) that influence the ability of the SEA to promote the integration of environmental and sustainability aspects in the development of actions in Brazil.

The purpose of this questionnaire is to identify the perception of SEA practitioners in the country about the effects promoted by SEA. The questionnaire structure is composed of 3 sections. The first section focuses on identifying SEA in which the respondent has been involved directly or indirectly. The second section has 23 questions organized into 7 categories, referring to the SEA potential outcomes on planning and decision making according to the literature. Finally, the third section aims to determine the professional profile of respondents.

The estimated time to complete this questionnaire is up to 40 minutes.

Thank you in advance for your willingness to cooperate with the development of this research.

Ghislain M. Tshibangu

PhD student

Marcelo Montaño

Professor advisor 
SECTION 1 - IDENTIFICATION OF SEAS

Please identify SEAs in which you have been directly or indirectly involved (if you are aware of another SEA that is not referenced, please use the space at the end to let us know.

\begin{tabular}{|c|c|c|c|}
\hline Year & SEA & Sector & Scope \\
\hline 1997 & SEA of Brazil Bolivia pipeline & Energy & Federal \\
\hline 2000 & $\begin{array}{l}\text { Regional environmental assessment of water resources } \\
\text { management and integration project }\end{array}$ & Energy & Ceará State \\
\hline 2002 & SEA of Chopim river basin & Energy & Paraná State \\
\hline 2002 & SEA of Areia river & Energy & Paraná State \\
\hline 2002 & SEA of IADB II, first phase, Curitiba & Transport & Curitiba City \\
\hline 2002 & SEA of the Multiannual Federal Plan & Planning & Federal \\
\hline 2002 & SEA of the Indicative Plan 2003-2012 & Energy & Federal \\
\hline 2003 & $\begin{array}{l}\text { SEA of Development Plans of Oil and Natural Gas } \\
\text { Exploration, Production, Transportation and Use in the } \\
\text { Southern Bahia Coast (Camamu-Almada Basin) }\end{array}$ & Energy & Bahia State \\
\hline 2003 & SEA of the National Axis Portfolio - Ministry of Planning & Multisector & Federal \\
\hline 2004 & SEA of the São Paulo Metropolitan Ring Road Program & Transport & Sao Paulo State \\
\hline 2004 & $\begin{array}{l}\text { SEA of the Igarapés de Manaus Social and Environmental } \\
\text { Program - PROSAMIM }\end{array}$ & Multisector & Amazonas State \\
\hline 2004 & PRODETUR Sul Programmatic Environmental Assessment & Tourism & Federal \\
\hline 2004 & Urban Consolidation of Paulínia & $\begin{array}{l}\text { Urban } \\
\text { development and } \\
\text { housing }\end{array}$ & Metropolitan \\
\hline 2005 & SEA of the Alto Paraguay Basin & Multisector & $\begin{array}{l}\text { Paraguay and } \\
\text { West Center of } \\
\text { Brazil }\end{array}$ \\
\hline 2005 & SEA of the Madeira River Complex & Energy & Federal \\
\hline 2005 & SEA of the Sao Paulo State Highway Recovery Program & Transport & Sao Paulo State \\
\hline 2005 & $\begin{array}{l}\text { SEA of the Accessibility Program for Small Municipalities } \\
\text { with Low Human Development Index - PROACESSO }\end{array}$ & Transport & $\begin{array}{l}\text { Minas Gerais } \\
\quad \text { State }\end{array}$ \\
\hline 2005 & $\begin{array}{l}\text { SEA of Rural Electrification Program of the Northwest of } \\
\text { Minas Gerais }\end{array}$ & Energiy & $\begin{array}{l}\text { Minas Gerais } \\
\quad \text { State }\end{array}$ \\
\hline 2005 & $\begin{array}{l}\text { SEA of the semi-arid Sustainable Development Program of } \\
\text { Sergipe }\end{array}$ & Planing & $\begin{array}{l}\text { North East of } \\
\text { Brazil }\end{array}$ \\
\hline
\end{tabular}




\begin{tabular}{|c|c|c|c|}
\hline Year & SEA & Sector & Scope \\
\hline 2006 & $\begin{array}{l}\text { SEA of the Industrial Complex - Pécem-CIPP Port and Area } \\
\text { of Influence }\end{array}$ & Multisector & Ceará State \\
\hline 2006 & $\begin{array}{l}\text { SEA of the Urban Environmental Quality Improvement } \\
\text { Program of Amapá }\end{array}$ & Sanitation & Amapá State \\
\hline 2007 & $\begin{array}{l}\text { SEA of the North Coast Sustainable Tourism Integrated } \\
\text { Development Plan }\end{array}$ & Tourism & Federal \\
\hline 2007 & SEA of the Road Program of Minas Gerais & Transport & $\begin{array}{l}\text { Minas Gerais } \\
\quad \text { State }\end{array}$ \\
\hline 2007 & SEA of the Rio Verde Sub-basin & Energy & $\begin{array}{l}\text { Mato Grosso do } \\
\quad \text { Sul State }\end{array}$ \\
\hline 2007 & $\begin{array}{l}\text { SEA of the Hydroelectric Generation Program in Minas } \\
\text { Gerais - PGHMG }\end{array}$ & Energy & $\begin{array}{l}\text { Mato Grosso do } \\
\quad \text { Sul State }\end{array}$ \\
\hline 2007 & SEA of the GDF / IADB Integrated Brasilia Program & Transport & $\begin{array}{l}\text { Federal District } \\
\quad \text { State }\end{array}$ \\
\hline 2007 & $\begin{array}{l}\text { SEA of the Northeast Tourism Development Program } \\
\text { (PRODETUR NE) }\end{array}$ & Tourism & North East \\
\hline 2007 & $\begin{array}{l}\text { Integrated Environmental Assessment of hydroelectric } \\
\text { facilities in the Tocantins River Basin }\end{array}$ & Energy & $\begin{array}{l}\text { Tocantins river } \\
\text { basin }\end{array}$ \\
\hline 2007 & $\begin{array}{l}\text { Integrated Environmental Assessment of hydroelectric } \\
\text { facilities in the Rio Doce Basin }\end{array}$ & Energy & $\begin{array}{l}\text { South East of } \\
\text { Brazil }\end{array}$ \\
\hline 2007 & $\begin{array}{l}\text { Integrated Environmental Assessment of hydroelectric } \\
\text { facilities in the Paranaíba River Basin }\end{array}$ & Energy & $\begin{array}{l}\text { Paranaíba river } \\
\text { basin }\end{array}$ \\
\hline 2007 & $\begin{array}{l}\text { Integrated Environmental Assessment of Hydroelectric } \\
\text { facilities in the Paraíba do Sul River Basin }\end{array}$ & Energy & $\begin{array}{l}\text { South East of } \\
\text { Brazil }\end{array}$ \\
\hline 2007 & $\begin{array}{l}\text { Integrated Environmental Assessment of Hydroelectric } \\
\text { facilities in the Uruguay River Basin }\end{array}$ & Energy & $\begin{array}{l}\text { Uruguai river } \\
\text { basin }\end{array}$ \\
\hline 2008 & SEA of the Anchieta Industrial and Services Pole & Multisector & $\begin{array}{l}\text { Espírito Santo } \\
\text { State }\end{array}$ \\
\hline 2008 & $\begin{array}{l}\text { SEA of the Expansion Plans for Eucalyptus and Biofuels } \\
\text { Forestry in the Far South of Bahia }\end{array}$ & Multisector & Bahia State \\
\hline 2008 & $\begin{array}{l}\text { SEA of the Program of Corumbá Mining-Industrial Pole } \\
\text { Development and Influences on the Pantanal Plain }\end{array}$ & Multisector & $\begin{array}{l}\text { Mato Grosso do } \\
\quad \text { Sul State }\end{array}$ \\
\hline 2008 & $\begin{array}{l}\text { Integrated Environmental Assessment of the Piquiri River } \\
\text { Basin }\end{array}$ & Energy & $\begin{array}{l}\text { Piquiri river } \\
\text { basin }\end{array}$ \\
\hline 2008 & $\begin{array}{l}\text { Integrated Environmental Assessment of the Rio Grande } \\
\text { Basin }\end{array}$ & Energy & $\begin{array}{l}\text { Grande river } \\
\text { basin }\end{array}$ \\
\hline 2009 & SEA of the Açu Industrial and Port Complex & Multisector & $\begin{array}{l}\text { Rio de Janeiro } \\
\text { Sate }\end{array}$ \\
\hline
\end{tabular}




\begin{tabular}{|c|c|c|c|}
\hline Year & SEA & Sector & Scope \\
\hline 2009 & $\begin{array}{l}\text { SEA of Plangas, GNL and COMPERJ developments in the } \\
\text { region around Guanabara Bay }\end{array}$ & Energy & $\begin{array}{l}\text { Rio de Janeiro } \\
\text { Sate }\end{array}$ \\
\hline 2009 & SEA of the Turvo River Basin & Energy & $\begin{array}{l}\text { Turvo river } \\
\text { basin }\end{array}$ \\
\hline 2009 & $\begin{array}{l}\text { Integrated Environmental Assessment of the Hydroelectric } \\
\text { facilities in the Xingu River Basin }\end{array}$ & Energy & Xingu river basin \\
\hline 2009 & $\begin{array}{l}\text { Integrated Environmental Assessment of the Teles Pires } \\
\text { River Basin }\end{array}$ & Energy & $\begin{array}{l}\text { Teles Pires river } \\
\text { basin }\end{array}$ \\
\hline 2009 & $\begin{array}{l}\text { Integrated Environmental Assessment of the Iratim River } \\
\text { Basin }\end{array}$ & Energy & Paraná State \\
\hline 2010 & SEA of the Mata Branca Project - Caatinga Biome & Multisector & Caatinga biome \\
\hline 2010 & $\begin{array}{l}\text { SEA of the Multimodal Transport and Mining-Industrial } \\
\text { Development Program of the Cacaueira Region - Porto Sul } \\
\text { Complex }\end{array}$ & Multisector & Bahia State \\
\hline 2010 & SEA of the Metropolitan Arc Master Plan & Transport & $\begin{array}{l}\text { Rio de Janeiro } \\
\text { Sate }\end{array}$ \\
\hline 2010 & $\begin{array}{l}\text { Strategic Environmental Planning of the Port, Industrial, } \\
\text { Naval and Offshore Dimension in São Paulo Coast - PINO }\end{array}$ & Multisector & Sao Paulo State \\
\hline 2010 & $\begin{array}{l}\text { Integrated Environmental Assessment of the Tibagi River } \\
\text { Basin }\end{array}$ & Energy & Paraná Sate \\
\hline 2010 & $\begin{array}{l}\text { Integrated Environmental Assessment of the Juruena River } \\
\text { Basin }\end{array}$ & Energy & $\begin{array}{l}\text { Mato Grosso } \\
\text { state }\end{array}$ \\
\hline 2010 & $\begin{array}{l}\text { Integrated Environmental Assessment of the Tijuco River } \\
\text { Basin }\end{array}$ & Energy & $\begin{array}{l}\text { Minas Gerais } \\
\text { state }\end{array}$ \\
\hline 2010 & $\begin{array}{l}\text { SEA of the Ceará Regional Urban Development Program - } \\
\text { Acaraú Valley }\end{array}$ & $\begin{array}{l}\text { Urban } \\
\text { development }\end{array}$ & Ceará state \\
\hline 2011 & $\begin{array}{l}\text { SEA of the set of actions included in the Integrated Tourism } \\
\text { Development Plan (PDITS) of the Costa das Dunas, Costa } \\
\text { Branca and Seridó tourist centers }\end{array}$ & Tourism & $\begin{array}{l}\text { Rio Grande do } \\
\text { Norte state }\end{array}$ \\
\hline 2011 & SEA of the Bioceanic Rail Corridor - Capricorn Axis & Transport & Federal \\
\hline 2011 & SEA of PRODETUR Rio de Janeiro - Coastal Polo & Tourism & - \\
\hline 2011 & SEA of PRODETUR Rio de Janeiro - Polo Serra & Tourism & - \\
\hline 2011 & $\begin{array}{l}\text { Integrated Environmental Assessment of the Aripuanã River } \\
\text { Basin }\end{array}$ & Energy & $\begin{array}{l}\text { Aripuanã river } \\
\text { basin }\end{array}$ \\
\hline 2011 & Integrated Environmental Assessment of the Jari River Basin & Energy & Jari river basin \\
\hline
\end{tabular}




\begin{tabular}{|c|c|c|c|}
\hline Year & SEA & Sector & Scope \\
\hline 2011 & $\begin{array}{l}\text { Integrated Environmental Assessment of the Araguaia River } \\
\text { Basin }\end{array}$ & Energy & $\begin{array}{l}\text { Araguaia river } \\
\text { basin }\end{array}$ \\
\hline 2011 & $\begin{array}{l}\text { Integrated Environmental Assessment of the Rio Branco } \\
\text { River Basin - Hydroelectric Inventory Study of the Rio } \\
\text { Branco / RR }\end{array}$ & Energy & Roraima state \\
\hline 2012 & Federal Road Transport (Transporte Rodoviário Federal) & Transport & Federal \\
\hline 2012 & Energy and Mining TAL (Energia e Mineração TAL) & Multisector & Federal \\
\hline 2013 & $\begin{array}{l}\text { Strategic Study of Public Policies in the Caatinga Biome } \\
\text { Area of the State of Bahia }\end{array}$ & Natural resources & Bahia state \\
\hline 2014 & $\begin{array}{l}\text { SEA of the National PRODETUR in the State of Mato } \\
\text { Grosso do Sul - Polo Campo Grande and Region }\end{array}$ & Tourism & - \\
\hline 2014 & $\begin{array}{l}\text { SEA of the National PRODETUR in the State of Mato } \\
\text { Grosso do Sul - Serra da Bodoquena Tourist Center }\end{array}$ & Tourism & $\begin{array}{l}\text { State of Mato } \\
\text { Grosso do Sul }\end{array}$ \\
\hline 2014 & Integrated Environmental Assessment of the Tapajós Basin & Energy & $\begin{array}{l}\text { Tapajós river } \\
\text { basin }\end{array}$ \\
\hline 2014 & $\begin{array}{l}\text { Social and Environmental Impact Assessment of the } \\
\text { Transport, Logistics and Environment Program }\end{array}$ & Transport & Sao Paulo state \\
\hline 2016 & $\begin{array}{l}\text { Strategic Environmental Revaluation of the Guanabara Bay } \\
\text { Coverage Area and Surrounding Region of COMPERJ }\end{array}$ & Energy & $\begin{array}{l}\text { Rio de Janeiro } \\
\text { state }\end{array}$ \\
\hline 2016 & $\begin{array}{l}\text { Piauí Inclusive Production for Sustainable Development } \\
\text { DPL }\end{array}$ & $\begin{array}{c}\text { Regional } \\
\text { development }\end{array}$ & Piauí state \\
\hline
\end{tabular}

Other

\section{SECTION 2 - IDENTIFICATION OF SEAS OUTCOMES}

Based on your experience, to what extent do you understand that SEA could have been responsible for promoting the outcomes described in the following questions? Use the scale provided to guide your answer. Please note that such outcome could occur on the SEA process or, even indirectly, on the strategic action planning process. If you have been involved in more than one SEA, please feel free to comment and clarify in the spaces provided if the outcome has been different from one SEA to another.

By answering this questionnaire, we understand that your participation was based on free, prior and informed consent. Further, essentially, your opinion will not be considered as representative of your company / institution's point of view.

Strategic action means the Policy, Plan, Program / Structuring Projects subject to the Strategic Environmental Assessment with which the respondent has been involved. 


\section{Orientation}

- - Strongly disagree: I am sure that this outcome was not influenced by the SEA.

- Partially disagree: it is likely that this outcome did not occur due to the influence of SEA.

O I do not agree or disagree: I cannot say that this outcome has occurred or not; My participation was limited.

+ Partially agree: likely this outcome occurred under the influence of SEA.

++ I totally agree: I am sure that this outcome was due to the influence of SEA.

\begin{tabular}{|l|l|l|l|l|l|}
\hline A. Is integrated & & & & $\begin{array}{l}\text { Considering the SEA in which you have been involved, } \\
\text { exemplify, if possible, by referring to the context in which such } \\
\text { outcome has occurred. }\end{array}$ \\
\hline According to your experience, it is possible that the SEA: & & & & & \\
\hline $\begin{array}{l}\text { 1. ensures an appropriate environmental assessment of all strategic } \\
\text { decisions relevant for the achievement of sustainable development? }\end{array}$ & & & & \\
\hline $\begin{array}{l}\text { 2. addresses the interrelationships of biophysical, social and economic } \\
\text { aspects? }\end{array}$ & & & & & \\
\hline $\begin{array}{l}\text { 3. Is tiered to policies in relevant sectors and (transboundary) regions and, } \\
\text { where appropriate, to project EIA and decision making? }\end{array}$ & & & & & \\
\hline $\begin{array}{l}\text { 4. SEA helps manage risk and minimize conflict when individual } \\
\text { projects are proposed? }\end{array}$ & & & & \\
\hline $\begin{array}{l}\text { If you would like to mention any other outcome regarding } \\
\text { integration, please use the space beside. }\end{array}$ & & & & \\
\hline
\end{tabular}




\begin{tabular}{|l|l|l|l|l|l|}
\hline B. Is sustainability-led & -- & - & $\mathbf{0}$ & $+\begin{array}{l}\text { Considering the SEA in which you have been involved, } \\
\text { exemplify, if possible, by referring to the context in which } \\
\text { such outcome has occurred. }\end{array}$ \\
\hline $\begin{array}{l}\text { 5. According to your experience, did SEA facilitates identification of } \\
\text { development options and alternative proposals that are more sustainable1? }\end{array}$ & & & & \\
\hline $\begin{array}{l}\text { If you would like to mention any other outcome regarding } \\
\text { Sustainability, please use the space beside. }\end{array}$ & & \\
\hline
\end{tabular}

\begin{tabular}{|c|c|c|c|c|c|}
\hline C. Is focused & - & $-\quad \mathbf{0}$ & + & ++ & $\begin{array}{l}\text { Considering the SEA in which you have been involved, } \\
\text { exemplify, if possible, by referring to the context in which } \\
\text { such outcome has occurred. }\end{array}$ \\
\hline \multicolumn{6}{|l|}{ According to your experience, it is possible that the SEA: } \\
\hline \multicolumn{6}{|l|}{$\begin{array}{l}\text { 6. provides sufficient, reliable and usable information for development } \\
\text { planning and decision making? }\end{array}$} \\
\hline \multicolumn{6}{|l|}{ 7. concentrates on key issues of sustainable development? } \\
\hline \multicolumn{6}{|l|}{ 8. is customized to the characteristics of the decision making process? } \\
\hline \multicolumn{6}{|l|}{ 9. is cost- and time-effective? } \\
\hline \multicolumn{6}{|l|}{ 10. includes both the positive and negative impacts on human health? } \\
\hline $\begin{array}{l}\text { If you would like to mention any other outcome regarding focus, } \\
\text { please use the space beside. }\end{array}$ & & & & & \\
\hline
\end{tabular}




\begin{tabular}{|l|l|l|l|l|l|}
\hline D. Is accountable & -- & $\mathbf{0}$ & + & + & $\begin{array}{l}\text { Considering the SEA in which you have been involved, } \\
\text { exemplify, if possible, by referring to the context in which } \\
\text { such outcome has occurred. }\end{array}$ \\
\hline According to your experience, it is possible that the SEA: & & & & & \\
\hline $\begin{array}{l}\text { 11. is the responsibility of the leading agencies for the strategic decision } \\
\text { to be taken? }\end{array}$ & & & & & \\
\hline $\begin{array}{l}\text { 12. is carried out with professionalism, rigor, fairness, impartiality and } \\
\text { balance? }\end{array}$ & & & & & \\
\hline 13. is subject to independent checks and verification? & & & & \\
\hline $\begin{array}{l}\text { 14. documents and justifies how sustainability issues were taken into } \\
\text { account in decision making? }\end{array}$ & & & & \\
\hline $\begin{array}{l}\text { If you would like to mention any other outcome regarding } \\
\text { accountability, please use the space beside. }\end{array}$ & & & \\
\hline
\end{tabular}




\begin{tabular}{|c|c|c|c|c|c|c|}
\hline E. Is participative & -- & - & $\mathbf{0}$ & + & ++ & $\begin{array}{l}\text { Considering the SEA in which you have been involved, } \\
\text { exemplify, if possible, by referring to the context in which } \\
\text { such outcome has occurred. }\end{array}$ \\
\hline \multicolumn{7}{|l|}{ According to your experience, it is possible that the SEA: } \\
\hline \multicolumn{7}{|l|}{$\begin{array}{l}\text { 15. informs and involves interested and affected public and government } \\
\text { bodies throughout the decision making process? }\end{array}$} \\
\hline \multicolumn{7}{|l|}{$\begin{array}{l}\text { 16. explicitly addresses their inputs and concerns in documentation and } \\
\text { decision making? }\end{array}$} \\
\hline \multicolumn{7}{|l|}{$\begin{array}{l}\text { 17. Has clear, easily-understood information requirements and ensures } \\
\text { sufficient access to all relevant information? }\end{array}$} \\
\hline \multicolumn{7}{|l|}{ 18. ensures the inclusion of marginalized populations? } \\
\hline $\begin{array}{l}\text { If you would like to mention any other outcome regarding } \\
\text { participation, please use the space beside. }\end{array}$ & & & & & & \\
\hline
\end{tabular}




\begin{tabular}{|c|c|c|c|c|c|c|}
\hline F. É iterativa & -- & - & $\mathbf{0}$ & + & ++ & $\begin{array}{l}\text { Considering the SEA in which you have been involved, } \\
\text { exemplify, if possible, by referring to the context in which } \\
\text { such outcome has occurred. }\end{array}$ \\
\hline \multicolumn{7}{|l|}{ According to your experience, it is possible that the SEA: } \\
\hline \multicolumn{7}{|l|}{$\begin{array}{l}\text { 19. ensures availability of the assessment results early enough to } \\
\text { influence the decision making process and inspire future planning? }\end{array}$} \\
\hline \multicolumn{7}{|l|}{$\begin{array}{l}\text { 20. provides sufficient information on the actual impacts of implementing } \\
\text { a strategic decision, to judge whether this decision should be amended } \\
\text { and to provide a basis for future decisions? }\end{array}$} \\
\hline \multicolumn{7}{|l|}{$\begin{array}{l}\text { 21. ensures system improvements and capacity building due to mutual } \\
\text { learning processes between consultants, public authorities and the } \\
\text { general public? }\end{array}$} \\
\hline $\begin{array}{l}\text { If you would like to mention any other outcome regarding iterativity, } \\
\text { please use the space beside. }\end{array}$ & & & & & & \\
\hline
\end{tabular}

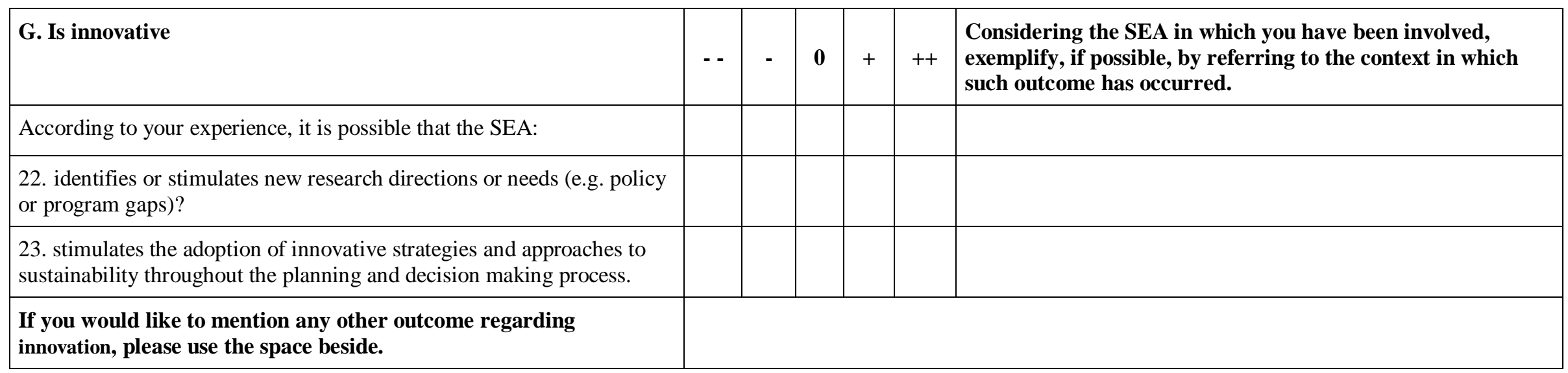




\section{SECTION 3 - RESPONDENT PROFILE CHARACTERIZATION}

The information provided in this section will be used to organize and analyze data collected. Confidentiality of respondents' personal data is maintained.

Institution where you were working when you get involved in the SEA process

Example: Ministry of Planning, National Secretariat of Tourism Development Programs.

( ) Federal Government Institution

Sector:

( ) State Government Institution

Sector:

( ) Municipal Government Institution

Sector:

( ) Educational and Research Institution

Sector:

( ) Businessman:

Sector:

( ) Non Governmental Organizations (NGOs)

Sector:

( ) Consultancy

Sector:

( ) Other:

Specify the sector:

Role played in the SEA process?

Example: coordinator of the SEA, technical support, thematic consultants

Position / Function in the institution

Example: Environmental Analyst, Infrastructure Analyst, Engineering Director

How long have you worked at the institution at the time of you participed in the SEA?

\section{Institution you currently work for}

Example: Ministry of Planning, National Secretariat of Tourism Development Programs. 


\section{Field of grduation}

Example: Biologist, Geographer

\section{Complementary Training}

Example: postgraduate (Master, Doctorate), specialization, $M B A$

Would you be available for an interview (in person, via telephone or Skype) to detail interest issues of of this research?

() Yes

( ) No

If so, please enter your name and email address in the spaces below.

Name:

Telephone:

E-mail:

Thank you for your participation.

If you would like information regarding the progress of this research, please contact Ghislain Mwamba Tshibangu via email at ghistshibangu@sc.usp.br or by phone at (15) 981112264 